\title{
POST-CONFLICT LAND ADMINISTRATION, FACILITATOR OF POST-CONFLICT STATE BUILDING
}


Examining committee:

Prof.dr.-ing. P.Y. Georgiadou

University of Twente

Dr. R.V. Sliuzas

Prof.dr.ir. G.E. Frerks

Prof.dr.ir. J. Crompvoets

Prof.dr. G. Barnes

Dr.ir. C.H.J. Lemmen

University of Twente

Utrecht University

KU Leuven, Leuven, Belgium

University of Florida, Gainesville, USA

Cadastre, Land Registry and Mapping

Organisation, the Netherlands

ITC dissertation number 282

ITC, P.O. Box 217, 7500 AA Enschede, the Netherlands

ISBN 978-90-365-4042-1

DOI $10.3990 / 1.9789036540421$

Cover designed by Job Duim

Cover photos: http://www.nato.int/kosovo/slides/m990513a.htm

Printed by ITC Printing Department

Copyright (c) 2016 by Dimo Todorovski

\section{UNIVERSITY OF TWENTE.}

17C FACULTY OF GEO-INFORMATION SCIENCE AND EARTH OBSERVATION 


\title{
POST-CONFLICT LAND ADMINISTRATION, FACILITATOR OF POST-CONFLICT STATE BUILDING
}

\author{
DISSERTATION
}

to obtain

the degree of doctor at the University of Twente, on the authority of the rector magnificus, prof.dr. H. Brinksma, on account of the decision of the graduation committee, to be publicly defended on 3 February 2016 at 14:45 hrs

by

Dimo Todorovski

born on $4^{\text {th }}$ June 1970

in Skopje, Republic of Macedonia 
This thesis is approved by

Prof.mr.dr.ir J.A. Zevenbergen, promoter

Prof.ir. P. van der Molen, promoter 


\section{Acknowledgements}

This research work is in its present form with immense support, dedication and contribution of different individuals and organisations to whom I am privileged to give sincere thanks and acknowledgement.

First and foremost, I would like to express my deepest gratitude to my promoters Prof. Jaap Zevenbergen and Prof. Paul van der Molen, who provided me with a consistent guidance and supervision throughout the whole research period. Your support, constructive comments and sharp advices during our discussions were with enormous importance and resulted with successfully completion of this research. Thank You from the bottom of my heart!

I would like to acknowledge the support provided by Kadaster (the Netherlands Cadastre, Land Registry and Mapping Agency) under the umbrella of UNU School for Land Administration Studies. Without this support and funding, this research would not have been accomplish.

It was a great fortune for me having the opportunity to work on research, education and projects at the Faculty of Geo-Information Science and Earth Observation - ITC. Faculty ITC with its unique international milieu of academic staff, experts, students and Alumni network is highly respected and known as a place where with a hard work you earn unforgettable memories, experience, knowledge and life-long friendships.

Enormous support and encouragements were received from the staff and PhD-ers from the PGM department and UNU School for Land Administration Studies, in the form of both formal and informal discussions. For this special thanks goes to Rohan, Walter, Liza, Arbind, Chrit, Johan, Bert, Peter, Monica, Mila, Kwabena, Jean-Francois/Jeff, Petra, Berhanu, Marie-Christine, Reshma, Adish, Eva-Maria and others.

I appreciate the time and contributions provided by all the people during the fieldwork and the interviews in Kosovo, and during the three separate fieldwork activities in Rwanda, performed by ITC Land Administration MSc's: Ms. Songo, Mr. Potel and Mr. Manirakiza. I acknowledge the time and feedback provided by all known and unknown reviewers of this research work and supporting papers and journals.

Second half of 2012 and 2013 was the most difficult period of my life. I lost my father Dušan - 'Dule Moj', and on personal note ... I'll keep this for myself. 
In the hardest times, support from family and closest friends is crucial. Here I would like to express special thanks and appreciation to all my cousins, especially Gjorgji and Vasil, relatives, godfathers Boban and Sašo, our Macedonian/Dutch family Kika Sander and Felix from Breda, and all my friends. Being an expat, your life path crosses with different people and cultures. Together with this one becomes enriched by its new 'international family', like our Kirgiz/Dutch family Turdukulov/Noomen, Solomon family from Poland, Hübner family from Germany, our Serbian family Mihajlović in Enschede, and many others. Thank you all for your support and cheering spirit during this, once in a lifetime journey. We shared together good and bad, pain and joy.

I would like to express my gratefulness to my mother Nada, my brother Branko, sister in law Irena, my nieces Duna and Joana, and my father in law Duško for giving me confidence, psychological support and always being there for me, my wife and my daughters.

Finally my deepest thankfulness and appreciations goes to my beloved wife Ana and my daughters Marija and Mina. Without my wife's sincere support, understanding, patience and knowing that this is for our better and brighter future, cheerful and always full of life Marija and Mina, this successful research would have not been accomplished. I'm a proud husband and father! 


\section{Table of Contents}

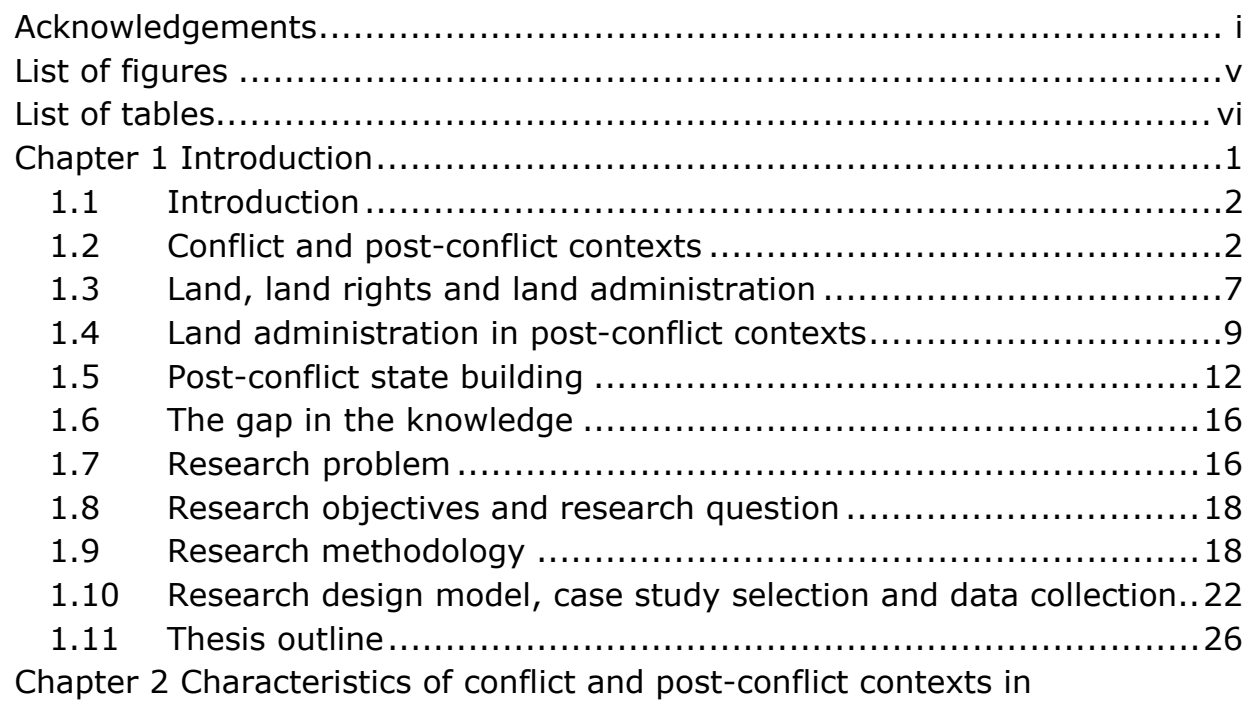

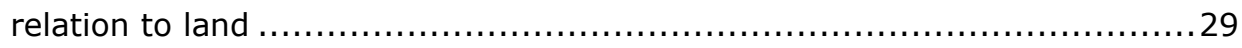

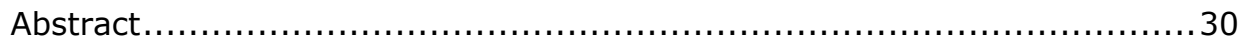

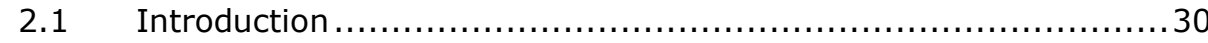

2.2 Characteristics of conflict and post-conflict contexts................ 31

2.3 Land and other resources in conflict and post-conflict contexts .... 36

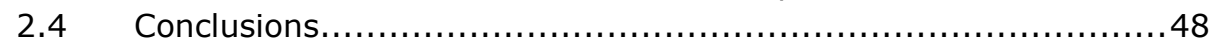

Chapter 3 Conflict and post-conflict land administration -

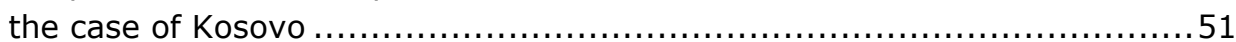

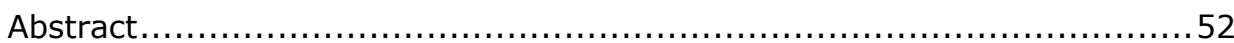

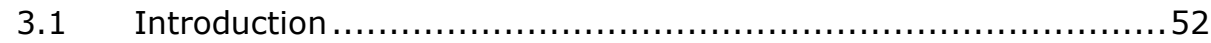

3.2 Conflict and post-conflict land administration, and post-conflict

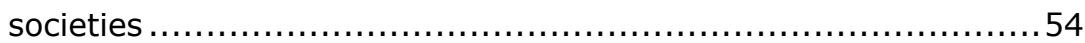

3.3 Before and during the conflict in Kosovo: how was land

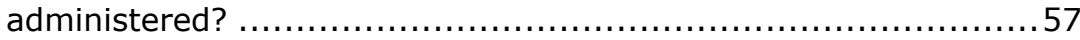

3.4 Emergency post-conflict Kosovo: housing and property rights and land administration ............................................... 63

3.5 Land administration in Kosovo in the early recovery post-conflict phase............................................................. 69

3.6 Land administration in Kosovo in the reconstruction phase..........73

3.7 Post-conflict societies: observations in particular for Kosovo........74

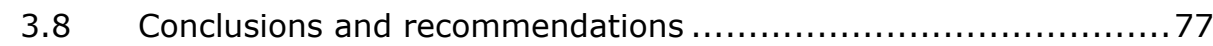

Chapter 4 Land administration for post-conflict contexts -

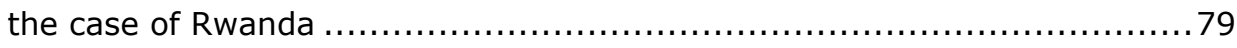

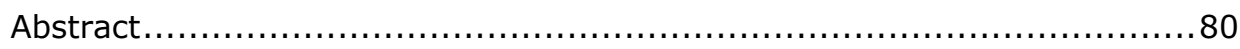

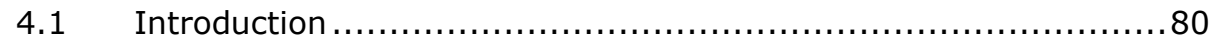

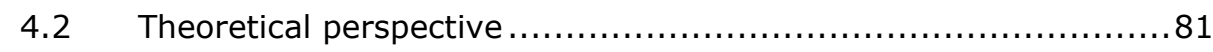




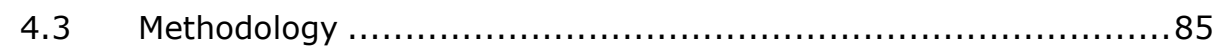

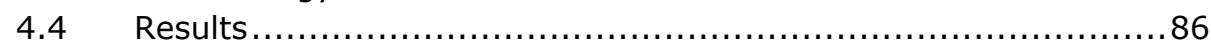

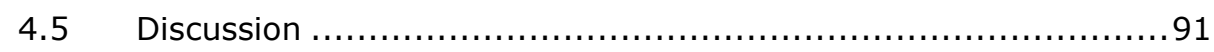

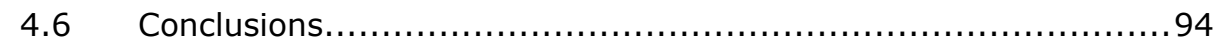

Chapter 5 How interventions in land administration facilitate post-conflict

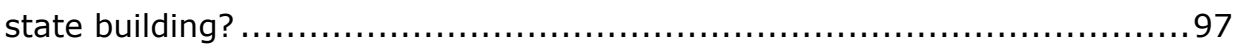

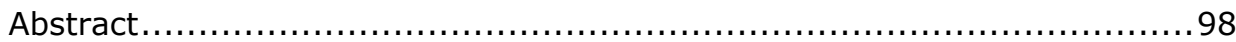

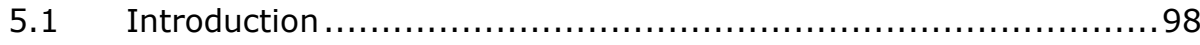

5.2 State building, land and its administration in post-conflict

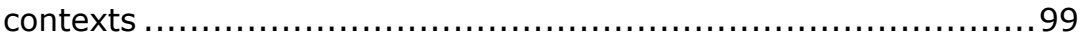

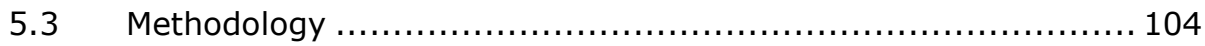

5.4 Lessons learned from the cases .................................... 106

5.5 Discussions and analyses ........................................ 116

5.6 Conclusions.......................................................... 121

Chapter 6 Conclusions and Recommendations ................................. 123

6.1 Introduction ....................................................... 124

6.2 Main conclusions from the research ................................. 125

6.3 Implications of the results...................................... 130

6.4 Recommendations for future research ............................ 132

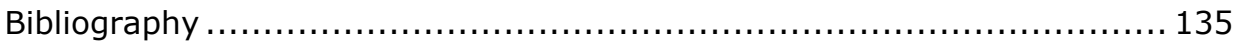

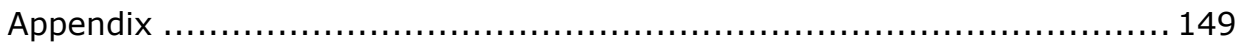

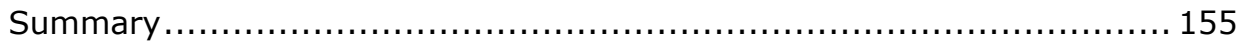

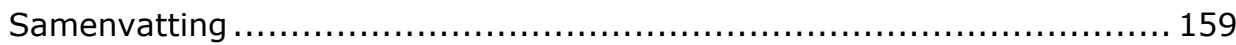

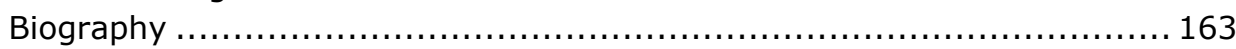

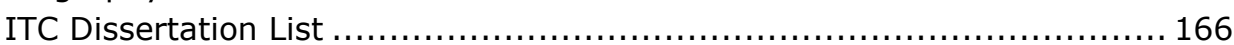




\section{List of figures}

Figure 1.1: The broad concept of land administration

Figure 1.2: The gap in the knowledge

Figure 1.3: Four elements of research design

Figure 1.4: The four elements of the research design relating to a qualitative methodology and a quantitative methodology

Figure 1.5: Outline of the research design model

Figure 1.6: Criteria model for case study selection

Figure 1.7: Proposed model for data collection

Figure 4.1: The gap in the knowledge 


\section{List of tables}

Table 1.1: Relevant situations for different strategies

Table 3.1: Interventions in housing and property rights and land administration in post-conflict society - Kosovo

Table 4.1: Characteristics of post-conflict state building focusing on the role of HLP and land administration - the case of Rwanda

Table 5.1: A framework for rebuilding a post-conflict state

Table 5.2: Interventions in land administration for post-conflict state building 


\section{List of Matrixes}

Matrix 5.1: Interventions in land administrationthat facilitate post-conflict state building 


\section{Chapter 1 \\ Introduction}

* This chapter is an extended version of a journal paper published as:

Todorovski, D., Zevenbergen, J. and van der Molen, P., (2012). Land administration in post-conflict environment - aspects relevant for South-East Europe. South-Eastern European Journal of Earth Observation and Geomatics, 1(2012)2S, pp. 47-59. 


\subsection{Introduction}

The causes of armed conflict and widespread violence are many and varied. In some cases land is a major cause. Land and land-related issues are increasingly recognized by the international community as an important element associated with conflict activities that take place before, during and specifically after the conflict (FAO, 2005; OCHA, 2005; UN-HABITAT, 2007, 2009).

This research addresses the role of land administration in post-conflict contexts. The focus is on identifying its potential role as a state building facilitator in the post-conflict period. First conflict and post-conflict contexts are explored based on the available literature. Then land, land rights and land administration, as well as characteristics of land administration in postconflict contexts are discussed. 'Land administration in post-conflict contexts' in this research is recognised as land administration performed in peace normal life conditions - loaded with the characteristics of the post-conflict contexts. The literature review continues on the processes of post-conflict state building in order to identify the characteristics of this subject with reflection on the land related issues. Fieldwork enables this research to identify the post-conflict situations with reflection on land administration, but more specifically it aims at identification of how land administration facilitates post-conflict state building in such fragile contexts. The research finishes with drawing conclusions about the identified need to better understand how land administration in post-conflict contexts can be recognised as a facilitator of the post-conflict state building and under which circumstances.

\subsection{Conflict and post-conflict contexts}

The causes for armed conflict and widespread violence are many. Throughout history, conflicts have been waged over land (Tibaijuka, 2007). In some cases land was one of the factors and sometimes land was a major cause for the conflict. In his paper Lewis (2004) posed a question: 'Are wars fought over land?, and the answer would be historically...yes'. Land is often a significant factor for widespread violence and also a critical element in peacebuilding and economic reconstruction in post-conflict situations (USAID, 2005).

A broad factor of many conflicts is the social, economic and political discrimination against groups in society, whether minorities or a majority of the population (FAO, 2005). Other causes for armed conflict could be: ethnic envy, nationalistic tendencies, opposing interests, class conflicts, disputed frontiers, expansion action or economic interests (van der Molen and Lemmen, 2004). Lewis (2004) discusses that wars in the last decades have 
been driven by long-simmering ethnic and religious ideologies and fuelled by a struggle for political and economic control.

It could be concluded that causes of conflicts are not only the land itself, but they always have a land dimension (Putzel, 2009; Todorovski, 2011).

There are several definitions of the word conflict in the available literature depending on the academic discipline: in social sciences, in peace and conflict studies, etc. As regards conflicts and land-related issues, definitions on: secondary conflicts and land conflicts, are available in the literature. McAuslan (2007) defines secondary conflicts as 'unregulated activity involving the land, housing and property sectors for which there are no mechanisms to resolve the conflicts between parties other than through using force and violence'. Land is one of the catalysts of secondary conflict which was illustrated by experiences in several post-conflict societies including Kosovo, Afghanistan, Somalia and Iraq. The lessons learned in these contexts need closer investigation and incorporation into planned future interventions emerging from war (Lewis, 2004).

Wehrmann (2005) describes land conflict as a social fact in which at least two parties are involved and the roots of which are different interests over the property rights to land - the right to use the land, to manage the land, to generate an income from the land, to exclude others from the land, to transfer land and the right to compensation for land. A land conflict, therefore, can be understood as a misuse of a restriction of or a dispute over property rights to land. Anten (2010) argues that the fact that land conflicts continue is due to inadequate formal and informal rules, and weak formal agencies. These weaknesses persist because they are an integral part of the workings of the political marketplace.

Nowadays, the nature of conflict has changed. Rarely do armies square off across borders. Since the end of the Cold War, conflict has moved inside national boundaries; civil wars and insurgencies are much more common today then wars between states (Zevenbergen and Burns, 2010). The attention drawn to wars between states has been replaced by a focus on internal wars of many kinds. A global preoccupation with internal instead of international conflict is now the rule. In addition, the justification of conflicts has changed: identity has replaced ideology (Jeong, 2000). Ethnic or national identity, existing or constructed, proved to be a powerful unifying force for building up constituencies. Political leaders convey a message to their supporters that unless one's own group dominates, it will be dominated by others (Buyse, 2008). 
Alden Wily (2009) argues that conflicts have moved from an inter-state to an intra-state context, and accordingly shifted into inter-communal and interclass conflicts, often complicated by ethnic concerns. Wallensteen (2002) distinguishes three basic types of armed conflict: international conflict, civil wars and conflicts over state formation.

There is increased involvement of international organisations in the armed conflicts that occurred in the last two decades. The number of these conflicts in which international organisations are involved has increased (Buyse, 2008).

\section{Post-conflict contexts}

The post-conflict period starts when the main hostilities have ceased, some kind of peace treaty document is signed and international assistance can be provided for emergency and recovery activities. This period generally could be subdivided into three time phases: emergency, early recovery and the reconstruction period. Activities in the emergency phase focus on establishing basic governance and providing humanitarian services. They are usually undertaken in the immediate aftermath of conflict and before full-scale mobilization of aid resources have started. During this period, there is often little or no operational governance and rule of law, and extensive destruction of infrastructure. Food security is low. These activities should be identified as short-term actions that can be implemented relatively quickly (FAO, 2005). This period is complex, fluid and enormously difficult.

According to Food and Agriculture Organisation (FAO) of the United Nations (UN) the general characteristics in the post-conflict contexts are: death and injury, hunger and starvation, displacement of people, negative social and psychological consequences, changes in values and expectations, destruction of infrastructure and housing, limited government capacity, limited funding and limited national 'ownership' of recovery plans (FAO, 2005). In all cases of post-conflict, the war machines inch their way across the landscape leaving behind the destruction of infrastructure, buildings and properties, the deaths and injuries, and problems of those survivors left behind (Lewis, 2004).

Conflicts often result in the massive displacement of people, creating large numbers of refugees and internally displaced persons (IDP). Sometimes people experience forced eviction during the conflict. Displaced people often settle on land to which they have no legal right. There is also an issue that remaining citizens occupy land and houses left by refugees/IDPs, this type of occupation is called secondary occupation. There is an important legal distinction between refugees and IDPs. Refugees are people who flee their homes for the safety in another country. IDPs are people who flee from 
violence but remain within their own country. The right of all refugees and IDPs to return to their homes and places of habitual residence in their country and/or place of origin is defined in relevant international legal instruments (UN, 1998). Once the armed conflict comes to an end or diminishes in intensity, one of the important issues that arises is that of restitution and compensation for those who have lost the assets they once possessed (Guterras, 2009).

In the emergency phase of the post-conflict period the first people on the ground are actors from humanitarian organisations and from the international community. These are usually logisticians and procurement people. Pantuliano in the Humanitarian Policy Group (HPG), during the book launch meeting, acknowledged that although awareness has increased, humanitarian organisations remain focused on returning land to IDPs and refugees rather than on wider structural issues and their effects on the population as a whole. De Waal discusses 'selective nostalgia': humanitarian agencies frequently try to 'return to the way things were', but these ideals are often unrealistic or even undesirable after processes of change and transition. There is a need to get to grips with the reality of change and how best to promote positive outcomes. There needs to be a shift from focusing solely on restitution to reform (HPG, 2008). It is important to stress this because activities undertaken in the emergency phase have an impact on the processes of peace and post-conflict state building in the long run.

There are cases where actions taken by donors were not well co-ordinated and there were some overlapping activities. In Afghanistan, multiple donors were involved - FAO, USAID, African Development Bank, the World Bank, UNAMA, UN-HABITAT - and they had different and uncoordinated policies and approaches to land (McAuslan, 2007).

A peace process is a formal process in which the warring parties either decide to settle the incompatibility in a process in which one issue at the time is regulated by an agreement, or where agreements that build on previous peace agreements are signed. Definition for a peace agreement is: 'an agreement signed by at least two of the warring parties addressing the problem of the incompatibility, either by settling all or part of it, or by clearly outlining a process for how the warring parties plan to regulate the incompatibility' (UU-DPCR, 2012).

De Wit in HPG (2008) underlines that there is a need to ensure that land issues are tackled in peace agreements and that these include an adequate follow-up. The issue of including housing land and properties (HLP) in peace agreements should be stimulated since it could act as a compromise in an often fragile peace. Nevertheless, making references to land can be 
important (even in fragile contexts) as it puts pressure on the issue not to be dropped off the political agenda. McAuslan (2007) argues that in immediate post-conflict situations, governmental institutions are weak and trust both in government and between people and communities is absent. What is needed, according to the Organisation for Economic Co-operation and Development $(O E C D)$, is a land policy which focuses on the political dynamics of the conflict over land rather than the technical dimensions of land administration. Land professionals with experiences in the development of land policy documents and with appropriate knowledge in post-conflict environment could significantly contribute this process (OECD, 2008).

\section{Land issues in post-conflict contexts}

When large numbers of refugees began to return to their homes in Afghanistan in 2002, for example, it quickly became apparent that they faced a host of land-related problems, such as illegal occupation by local commanders, disputes arising from the loss and destruction of ownership documents, fraudulent transactions, land distribution by successive governments to their political supporters, and disputes over grazing and water rights (Guterras, 2009).

Too few people with a background in land are engaged in the topic of postconflict contexts. This specific context requires engagement of different actors to come and work together in the early stages of a post-conflict period. Pantuliano, underlining the critical importance that land issues play in conflict and post-conflict situations, also stressed the need to bring land tenure expertise to the humanitarian community (HPG, 2008).

Pantuliano (2009) clarifies that the HPG programme of the Overseas Development Institute originated from the concern that, despite increasing evidence that land is often a critical issue in conflict-affected emergencies and forced displacement and plays a key role in post-conflict reintegration and reconstruction processes, there is a perceived lack of humanitarian engagement on HLP issues. Emergency measures such as the creation of IDP's camps and other settlements are de facto interventions in land management and land tenure (de Waal, 2009). Acting on land issues in a post-conflict environment is of crucial importance in order to support a peaceful transition from conflict. The management of land relations is intrinsically linked to a range of peace benefits (Cramer and Weeks, 2002). Disputes over land are often an underlying cause of, and factor in, conflict, especially in protracted crises (Pantuliano, 2009).

Establishing (or re-establishing) tenure security can be very complicated in countries emerging from years of conflict, especially where land records are 
not available or badly organised, and where statutory and customary systems overlap (Fitzpatrick, 2008).

Land disputes and land claims: It is critical that due attention is paid to resources of new or on-going conflict. One of these is the resolution of land and property disputes arising either from a displaced population returning, or from internecine struggles for primacy over land and property rights (Lewis, 2004). With the end of an armed conflict, especially a prolonged one involving significant displacement, a large proportion of the affected population will claim or reclaim access to land and resources. This has important implications for return, recovery and reintegration processes (Pantuliano, 2009).

OECD-DAC guidelines have identified land tenure and administration as a critical area of action, and stress that disputes related land holdings must be addressed as rapidly as possible once the violence has subsided (OECD-DAC, 2007). It is important that land claims and grievances be addressed promptly at the end of a conflict. If these issues are overlooked, property disputes will inevitably escalate and may risk threatening the usually fragile stability of a post-conflict transition. The increase in land and property disputes in the post-conflict period usually stems from the failure to understand or constructively manage post-conflict land and property relations (Pantuliano, 2009). One of available manuals is FAO manual for land tenure alternative conflict management, which focuses on how to manage and resolve conflicts land tenure rights, security of tenure and land access, addressing specifically areas where conflict is increasingly evident (FAO, 2006).

\subsection{Land, land rights and land administration Land and Land Rights}

As described in United Nations Economic Commission for Europe (UN/ECE) land can be recognized as a source of all wealth. Land is a place of all shelter, in the city, the town, the village, and at home. It is the source of food, of materials for construction and manufacture, of coal, gas and oil, of springs and rivers and other essentials for life. Indestructible, immovable, it is the foundation of all human activities. Houses and factories, forests and farms, river roads and railways, mines, quarries, and reservoirs are all fashioned from the land. It offers endless opportunities for development and discovery (UN/ECE, 2005). From land administration perspective 'Land' is to be considered as the surface of the earth, the materials beneath, the air above, and all things fixed to the soil, so it is more than just 'land' alone: it includes buildings, etc. (van der Molen, 2002). 'Recognizing that land is a source of wealth lies at the heart of good government and effective public administration' (UN/ECE, 2005). 
There is a tight relationship between humankind and land, and it is represented in a form of rights, interest and responsibilities to land. Rights on land can be divided mainly in two groups: statutory and customary rights and they may be defined in the statutory or common law and by the customary traditions or informal use (van der Molen, 2002). Within the statutory or common law - or so called formal system - rights to land and the real estate are clearly described in the appropriate legislation addressing the land issues, and because these rights to land and real estate are gained via legal instruments it can be assumed that these rights are protected and secured to the right holder. Examples of rights to land and real estate are: ownership, leasehold, freehold, easements, superficies and rights to profit. Customary traditions (or customary law) are based on unwritten rules which find their legitimacy in tradition and these traditions can be different depending on culture, social aspects, economic and political factors.

\section{Land Administration}

The UN/ECE Land Administration Guidelines defines land administration as 'the process of determining, recording and dissemination information about tenure, value and use of land when implementing land management policies' (UN/ECE, 1996).

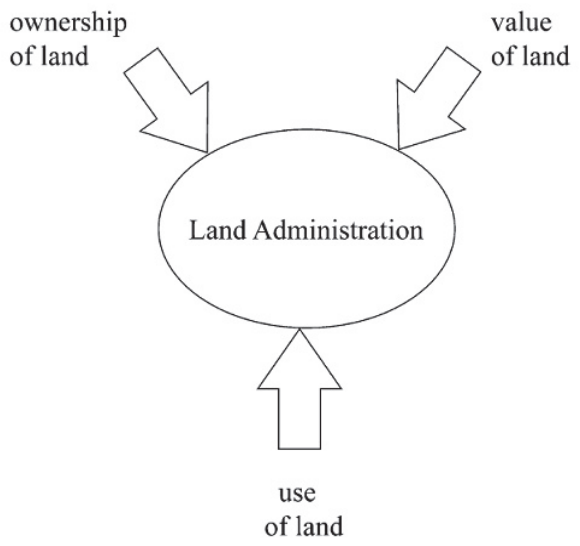

Figure 1.1: The broad concept of land administration (van der Molen, 2002)

Another definition is: land administration is the process of regulating land and property development and the use and conservation of the land; the gathering of revenues from the land through sales, leasing, and taxation; and resolving of conflicts concerning ownership and use of land (Dale and McLaughlin, 1999).

Land registration and cadastres make up an important part of land administration (Zevenbergen, 2002). McLaghlin and Nichols (1989) described 
land registration as 'the process of recording legally recognized interests (ownership and/or use) in land'. Henssen and Williamson (1990) define land registration as a process of official recording of rights in land through deeds or titles (on properties). It means there is an official record (the land register) of rights on land or of deeds concerning changes in the legal situation of defined units of land. It gives the answer to the question "who" and "how". Dale and McLaughlin (1999) argue that land registration provides the framework and means for recognizing formalized land ownership rights and for regulating the transfer of these rights.

Cadastres have registered the human terrain for centuries (Batson, 2008). According to UN (1985) cadastre is a methodologically arranged public inventory of data on the properties within a certain country or district based on a survey of their boundaries; such properties are systematically identified by means of some separate decision. The outlines of the property and the parcel identifier are normally shown on large-scale maps. FIG (1995) defines the cadastre as: normally a parcel-based, up-to-date land information system containing a record of interests in land (e.g. rights, restrictions and responsibilities). It usually includes a graphical description of land parcels linked to other records describing the nature of the interest, the ownership or control of those interests, and often the value of the parcel and its improvements. 'Land administration systems and in particular their central cadastral components are essential parts of countries national infrastructures' (UN/FIG, 1999).

\subsection{Land administration in post-conflict contexts}

The post-conflict contexts with regards to HLP are highly complex and multidimensional and it is not possible to develop guidelines for all aspects for all countries and scenarios simultaneously (UN-HABITAT, 2007). Many of those conflicts have a direct effect on the control over land and the rights of people relating to land and cause innumerable denials of HLP rights (Tibaijuka, 2007). Some of the land challenges that arise in post-conflict situations include: loss or destruction of property, secondary occupation, landlessness, insecure use or mobility rights and lack of clarity regarding ownership or use rights (Zevenbergen and Burns, 2010). Addressing these fundamental challenges, dealing with land administration in post-conflict situations, is no longer a matter of choice, but a core responsibility of effective peace building. Once it is understood that HLP issues may trigger secondary or tertiary conflict, it is important for peace-building missions to become aware that proposals related to land management in post-conflict situations are an integral part of efforts to restore peace and stability (UNHABITAT, 2007). 
Land administration related issues that come up in the post-conflict contexts are: access to land, land administration systems that support tenure security, forced transactions, emergency occupation of land (e.g. emergency camps, settlements for refugees and IDPs, etc.) and HLP rights (Zevenbergen and Burns, 2010).

Land administration in post-conflict contexts obviously is a difficult matter that requires an approach that copes with the local situation (van der Molen and Lemmen, 2004). Alden Wily in HPG (2008) argues that property issues in post-conflict contexts are often the same as those in states not affected by conflict but are just more loaded with the characteristics of the post-conflict settings. Land administration systems can suffer in several ways during a conflict. The most obvious blow follows from the loss of staff and records (Zevenbergen and Burns, 2010).

\section{Land professionals}

Staff can be killed, (forced to) leave the area or not able or willing to return to their jobs within the systems of land administration. In all cases it is important to quickly identify available experienced staff and try to get them back to work as soon as possible. Most land administration staff are professionals with specific expertise, and except for (top) managers their position should not be political, but this depends much on local circumstances (Zevenbergen and Burns, 2010).

Experiences show that too few of the engaged personnel in the emergency phase have appropriate knowledge and skills in land administration issues which have their specific characteristics and need adequate approach for land administration in a post-conflict context (HPG, 2008; Pantuliano, 2009).

When - at the end of the day - a land registrar writes down a name of an owner in a land book, and a land surveyor draws a boundary line on a cadastral map, it could be either the start of a prosperous economic development, or the overture to a new conflict. The work of land surveyors and land registrars can be seen in the context of state building (van der Molen, 2011).

\section{Land records}

Land records are the evidence of ownership and user's rights. Land records are typically associated with formal land administration. In countries where land is administered through customary bodies, where formal legal systems are not accessible to significant parts of the population, records are kept locally and transactions recorded through simple sales contracts, witness 
statements or local knowledge and attribution. Incomplete, out of date or contested land records can pose a threat to tenure security that is heightened in settings characterized by legal pluralism where statutory law does not recognize the existence of any other valid system of rights (UN-HABITAT, 2009). According to UN-HABITAT (2009) the issues about land records in post-conflict situations that require appropriate attention are: inadequate land records; fragmented responsibility for land records; lost, stolen or fraudulent land records; and women's and children's property and inheritance rights.

In Timor-Leste the land and property buildings were among the first destroyed by militia activity along with most property rights records. Also in Somalia, land registries for the valuable, irrigated areas in the central part of the country have been largely destroyed and will lead to significant problems once a central government and peace prevail (Unruh, 2004).

\section{Summary on land administration in post-conflict contexts}

In post-conflict situations, land (and related housing and property) issues are even more urgent and complex. No matter how difficult concerted action might seem in the chaos and confusion following a conflict, land questions have to be dealt with as early as possible (Du Plessis, 2003). Historically, land administration issues have not been figured prominently in UN emergency and peace building operations. While some UN missions (including cases when UN exercised transitional governing functions, such as those in Kosovo and Timor-Leste) addressing land administration problems in postconflict areas, most missions either do not address these issues at all, or if attention is paid, it was generally ad hoc and limited in nature (UN-HABITAT, 2007). The relationship to land administration and land policy is relevant and should be recognized in peace treaties. Parties involved in the formulation of peace agreements and/or strategic action plans should mention land registration not as an isolated objective but rather embed in such plans a wider development and land policy (van der Molen and Lemmen, 2004). Land administration is the appropriate instrument for implementation of the national land policy. Failure to address land issues in post-conflict contexts can create significant obstacles to humanitarian interventions and early recovery responses and, if unaddressed, may contribute to renewed violence.

'Land administration in post-conflict contexts' in this research is recognised as land administration performed in peace living conditions, but loaded with the characteristics of the post-conflict contexts. This phenomenon needs attention, an evidence-based research is needed that will define and determine the characteristics of 'land administration in post-conflict contexts'. 


\subsection{Post-conflict state building}

After a war sometimes a new state is formed or the old one is coming out of the conflict. Both need to follow a post-conflict state building process. The first challenge that these states are facing is a peace-keeping process. The cessation of armed hostilities is not the complete watershed it may seem to be. A ceasefire is only a temporary success on the long road to peace (Bruce, 2007). There are two situations of peace, negative peace (absence of violence but nothing more than that) and positive peace (reconciliation among the parties). Peace building consists of actions undertaken by international or national actors to institutionalize peace, understood as the absence of armed conflict and at least a modicum of political process (Call and Cousens, 2008).

Because the post-conflict period is complex, fluid and enormously difficult and the state and the peace are fragile, all actors involved in the process of post-conflict state building should be aware of this fragile situation and the importance to keep peace in place. The peace-building process should run parallel to the long-term post-conflict state building.

\section{Fragile states}

Recent years have seen an increasing concern among the policy-makers about 'weak', 'failing' and 'fragile' states. State fragility may be manifested in various forms and degrees. The chief concern is risk of conflict or humanitarian disaster. OECD (2008) discusses that 'states are fragile when states' structures lack political will and/or capacity to provide basic functions needed for poverty, development and to safeguard security and human rights of their populations'.

Fragility of states and situations is understood as a situation where weaknesses in the dynamic political process obstruct the matching of citizens' expectations of the state with the state's capacity to deliver. It is the opposite of resilience (Anten, 2009). Resilience can be defined in relation to a state (and society), or to governance. Resilience in relation to a state is defined as the ability of state and society to manage state-society expectations and to keep expectations and capacity in balance. Together, capacity, institutions, legitimacy and effective processes combine to produce state resilience (OECD, 2008).

\section{States and Nations}

State is defined as the institutions of government consisting of both those making political decisions and those acting on political instruction (Whaites, 2008). The literature makes a clear distinction between Nation and State: a 
'Nation is a social group sharing common ideology, institutions, language and homogeneity', while a 'State is a legal concept describing a social group that occupies a certain territory and is organised under common political institutions and an effective government'. To say it more easily: a Nation is a tight-knit group with a common culture, and a State is a self-governing entity (van der Molen, 2011). According to Call and Cousens (2008) nation building consists of actions undertaken, mostly by national actors, to forge a sense of common nationhood, usually with the purpose of overcoming ethnic, sectarian, or communal differences, and countering alternate sources of identity and loyalty, and mobilizing a population for a parallel state-building project.

\section{State building}

State building is defined as purposeful action to build capacity, institutions and legitimacy of the state in relation to an effective political process to negotiate the mutual demands between the state and societal groups (OECD, 2008). 'State building', is the construction of the foundation of the government edifice, within which governance ought to operate (van der Molen, 2011).

The first priority of state building must be a form of political governance, and the formulation of a set of political processes or accountability mechanisms through which the state and society reconcile their expectations of one another (Anten, 2009). Focusing on governance structures that address inequities and inequalities and promote accountability is likely to promote stability over time. State building in fragile states is a critically important but highly challenging function. The complexity and context specificity of the state formation process as well as limits on external influence mean that sustained, serious efforts as well as research and policy innovation are urgently needed. Successes will contribute to human security, development, and international stability - benefits warranting substantial national and international engagement (OECD, 2008). The distinction should be recognized that state building is not peace building and it is not nation building.

\section{Post-conflict state building or rebuilding war-torn societies}

Ball (2001) distinguishes three types of characteristics for rebuilding postconflict societies: institutional weaknesses, economic and social problems, and serious security problems. Because her views are widely accepted, they will be used as basic concept for this research. Details of Ball's (2001) concept, other available concepts and adaptation of a framework for 
rebuilding of post-conflict societies for this research are presented in Chapter 5.2 .

Appropriate policies should be developed and implemented to overcome these problems. Post-war states present both a major challenge and a major opportunity. Three dimensions of policy should be the focus of post-war engagement: political processes that legitimate the state, the development of the framework of the rule of law including that related to economic governance, and the re-establishment of a framework of security including but not limited to the reconstitution of the state security apparatus (OECD, 2008).

Getting from a situation of negative peace to positive peace requires some form of doing justice. If justice is required, rule of law becomes one of necessary perspectives for looking at the given post-conflict environment. Apart from being an aspect of rebuilding the rule of law, housing and property restitution can make a practical contribution to peace (Buyse, 2008). Wallensteen (2002) emphasizes that in the post-settlement phase it is important to undo the effects of war. This entails economic redevelopment and the restoration or creation of democratic institutions, but also the return of refugees and displaced persons.

In the last two decades, the number of international post-conflict operations has substantially increased. These operations have proved to be complex and results have been mixed. Important policy lessons are beginning to be learned, e.g. 'that policies are most effective when they are integrated, striking the right balance between security, governance and socio-economic development' (Anten, 2009). The increased involvement of international organisations may have a double effect. Weakening or destruction of domestic institutions caused by conflict increases the need for international remedies. More international involvement in modern conflict may then have a beneficial effect. The downside of international involvement is dependency. Mechanisms that are installed and maintained by international actors can easily collapse as soon as the latter leave the arena. Either the international organisations should finish the process started before they leave or the system of settlement and enforcement should be firmly rooted in a specific country's systems, making it independent of international presence as far as possible (Belloni, 2001).

\section{Post-conflict state building with reflection to land issues}

Experiences show that there are only a few cases where land issues were adequately addressed in the post-conflict period. Humanitarian organisations in this period mainly focus on IDP's and refugee-related issues, and a 
restitution of the situation as it was before the conflict. Some opinions are that land issues should be addressed as early as possible in the emergency post-conflict phase and preferably this should be incorporated in the broader post-conflict state building context.

Unruh in HPG (2008) argues that during the peace process state authorities are weak. After a war, where the political environment is most fragile, new regimes often lack capacities and political will to address the land and landrelated issues. That's why there is a need to raise the awareness of the importance of the land issues in this period and overcome the political and practical barriers when dealing with land in post-conflict states.

Good governance is of particular importance in post-conflict state building. To transfer its criteria (sustainability, subsidiarity, equality, efficiency, transparency, accountability, public participation and security) on land policy and land management would provide a good basis for sustainable and lowconflict development. The due establishment of this positive framework is of a crucial importance, especially in situations of crises such as in post-conflict countries (Wehrmann, 2006).

Restitution of housing and property rights seems to have at least a potential to make a positive contribution to peace. It serves as a legal tool to solve destabilizing refugee problems and it may help to cure at least one and maybe two of the previously mentioned three characteristics of war-torn societies (Buyse, 2008).

A sound definition of property rights and their registration in a land administration system definitely belongs to the necessary institutions to build a state, as is shown in the dissertation The Human Right to Property of the late $\mathrm{dr}$. Theo van Banning, the Dutch representative to the FAO in Rome (van der Molen, 2011). In most developed countries, the land administration systems are so naturally embedded in alignment with the social and economic functionalities of a state that it goes almost unnoticed by the community that they are serving.

Since land issues have often triggered armed conflict, and land management has been found to be an integral part of the political order, it would follow that an improvement in the land conflict resolution mechanisms would contribute to both peace-building and state building (Anten, 2010). Restitution processes can indeed be a beneficial factor in rebuilding societies (Buyse, 2008). 
Elaborating on the topics above, it could be concluded that the phenomenon of land administration in post-conflict contexts might be recognised as one element of the overall post-conflict state building process.

\subsection{The gap in the knowledge}

From the literature review it could be concluded that the topics of conflict and post-conflict contexts, post-conflict state building and land administration in post-conflict contexts are adequately addressed in the literature. The relationship or link between conflict and post-conflict contexts and postconflict state building, as well as between conflict and post-conflict contexts and land administration in post-conflict contexts is also acknowledged in the literature. A gap in the knowledge could be identified in the literature addressing land administration in post-conflict contexts in relation to postconflict state building. This research has the intention to tackle this gap.

Here follows a graphical representation which indicates the gap in the knowledge and the area that this research is going to explore in depth.

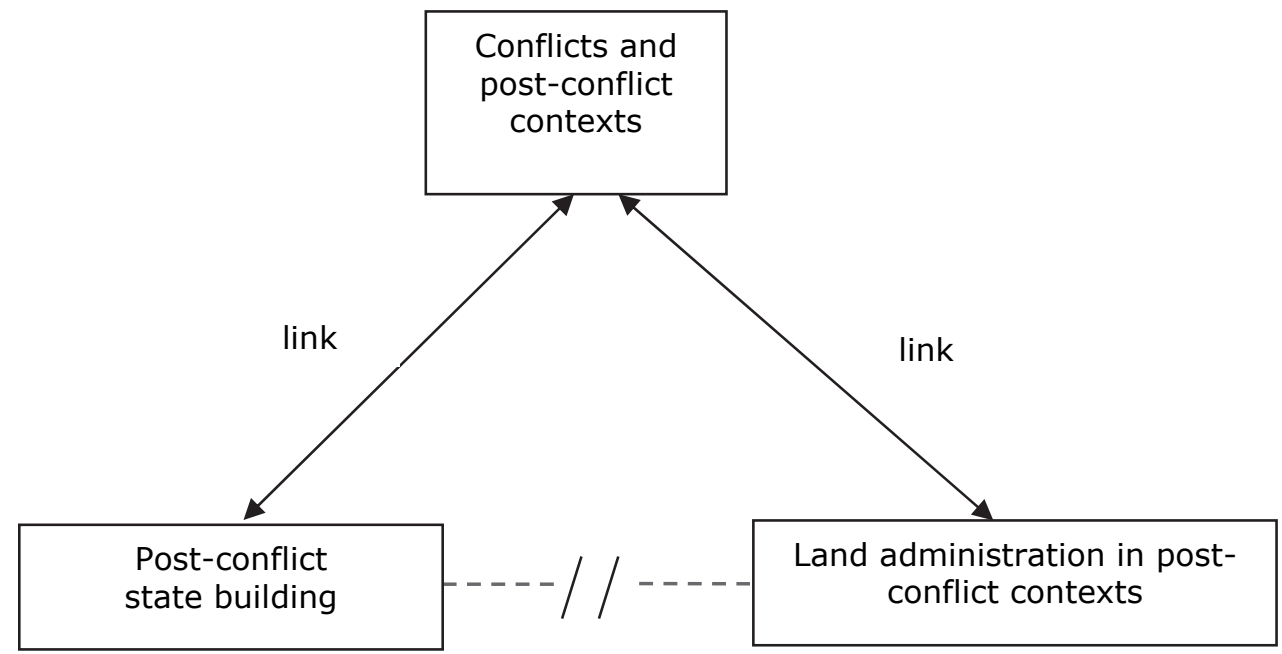

Figure 1.2: The gap in the knowledge

\subsection{Research problem}

There is a very specific (sometimes too complex) correlation between land and conflict. Guterras (2009) argues that land and property issues arise at every point in the cycle of violence that is to be seen in so many countries throughout the world. Land was identified as a critical gap in international response capacities (OCHA, 2005). The past two decades have been witness to a growing understanding of the vital importance and addressing HLP rights concerns within the context of post-conflict peace building (UN-HABITAT, 
2007). On the other hand, experiences show that there are only a few cases where land issues were addressed in the post-conflict period, and humanitarian organisations in this period mainly focus on IDPs and refugeerelated issues, and restitution of the situation as it was before the conflict.

Even though the awareness about the importance of land and land-related issues in post-conflict contexts has increased within the international community and we are facing an increased quantity of literature about the topic of land issues in the post-conflict contexts (basically on what to do about land, land management and land administration in post-conflict contexts), actors involved with the topic are underlining the need that more in-depth research in this specific area is required which will be evidencebased.

There is an identified need to ensure that land issues are put on the agenda of the international community and that they are tackled in the peace treaty documents or National Land Policies of the states emerging from conflict. Land administration is the appropriate instrument for implementing this, with a number of functions like support in establishment of the land market, land use, setting the tax and management of the state land. The goal of a land administration process is to support the implementation of land policy using the aspects of land management (van der Molen, 2002). Some opinions are that land issues should be addressed as early as possible in the emergency post-conflict phase and that, preferably, these should be incorporated in the broader post-conflict state building context.

A post-conflict period is complex, fluid and enormously difficult. After a war sometimes a new state is formed or the old one coming out of the conflict, both need to follow a post-conflict state building process. As said, statebuilding is defined as a purposeful action to build capacity, institutions and legitimacy of the state (OECD, 2008). Ball (2001) distinguishes three types of characteristics of war-torn societies: institutional weaknesses, economic and social problems, and serious security problems. An identified gap in the literature is on the potential that land administration could have for the broad post-conflict state building process.

Having an overview of the post-conflict situations, potential of land administration as an instrument and acknowledged characteristics of the wartorn societies, it could be concluded that land administration can be seen as a facilitator of the overall process of post-conflict state building. This brings us to the main research objective. 


\subsection{Research objectives and research question}

The main research objective of this research is:

Explore and identify interventions in land administration in post-conflict contexts that facilitate the post-conflict state building.

\section{Sub-objectives}

After the main research objective has been formulated there follows a list of sub-objectives which would lead to the main research objective:

SO1: Examine the characteristics of conflict and post-conflict contexts in relation to land;

SO2: Explore and identify specific interventions in land administration for post-conflict contexts;

SO3: Recognize the characteristics of the post-conflict state building with focus on land issues;

and

S04: Assess which interventions in land administration in post-conflict contexts took place and how those interventions could be recognised as facilitators of post-conflict state building.

\section{Main research question}

In order to achieve the main research objective an answer should be given to the main research question:

Can land administration in post-conflict contexts facilitate the post-conflict state building and under which circumstances?

\subsection{Research methodology}

The nature of any research problem and objectives determines the research methodology to be adopted and methods to be used. In this sub-chapter first an overview of the available and most frequently used research methodologies in the domain of land administration is given, then the most appropriate research methodology and research strategy are chosen based on analysis of the type and characteristics of the research question and the objectives. 
In order to undertake an appropriate research, initially basic elements of the research design are to be acknowledged. Here follows a diagram with the four main elements of the research design:

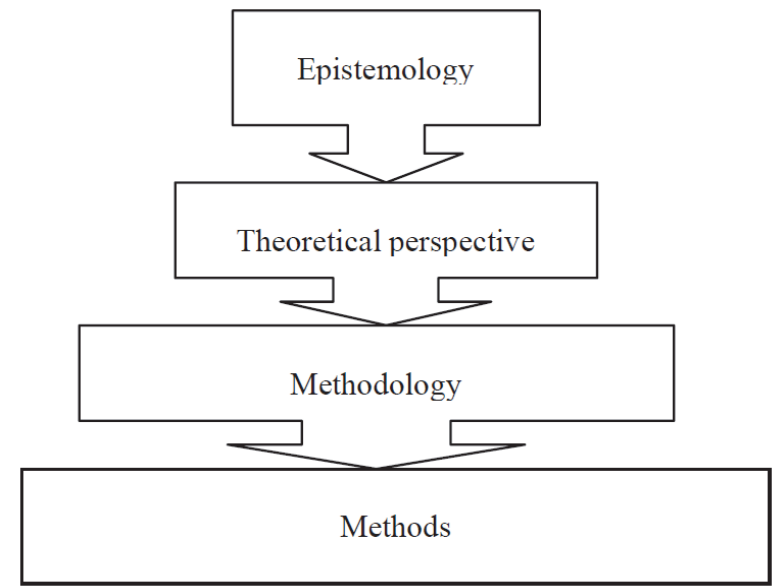

Figure 1.3: Four elements of research design, source Crotty (1998)

Epistemology is concerned with providing a philosophical grounding for deciding what kinds of knowledge are possible and how we can ensure that they are both adequate and legitimate. The theoretical perspective can be described as the philosophical stance informing the methodology and thus providing a context for the process and grounding its logic and criteria methods and linking the choice and use of methods to the desired outcomes. Methodology is defined as the plan of action and methods are techniques or procedures used to gather and analyse data related to some research objective, question or hypothesis (Crotty, 1998).

Levy (2006) argues that research gained using the quantitative method leads to results which are typically generalizable and sometimes quantifiable. If the aim is to uncover the issues or a factor underlying that phenomenon, as is the case for this research, then this research requires the use of the qualitative research methodology and the possibility to interpret the results based on theoretical perspective.

Qualitative research methodologies are defined as 'any kind of research that produces findings not arrived at by means of statistical procedures or other means of quantification' (Strauss and Corbin, 1998) and 'the label qualitative method has no precise meaning in any of the social sciences. It is an umbrella term covering an array of interpretive techniques which seek to describe, decode, translate and otherwise come to terms with the meaning, not the frequency, of certain more or less naturally occurring phenomena in the social world' (Cassel and Symon, 1994). 
Qualitative research methods examine the how, what and why of various phenomena. To put it simply, qualitative methods involve a researcher describing the characteristics of people and events without comparing events in terms of measurements or amounts (Thomas, 2003).

Here follows a diagram which gives an overview of the four elements of the research design relating the elements of research design to qualitative and quantitative methodology:

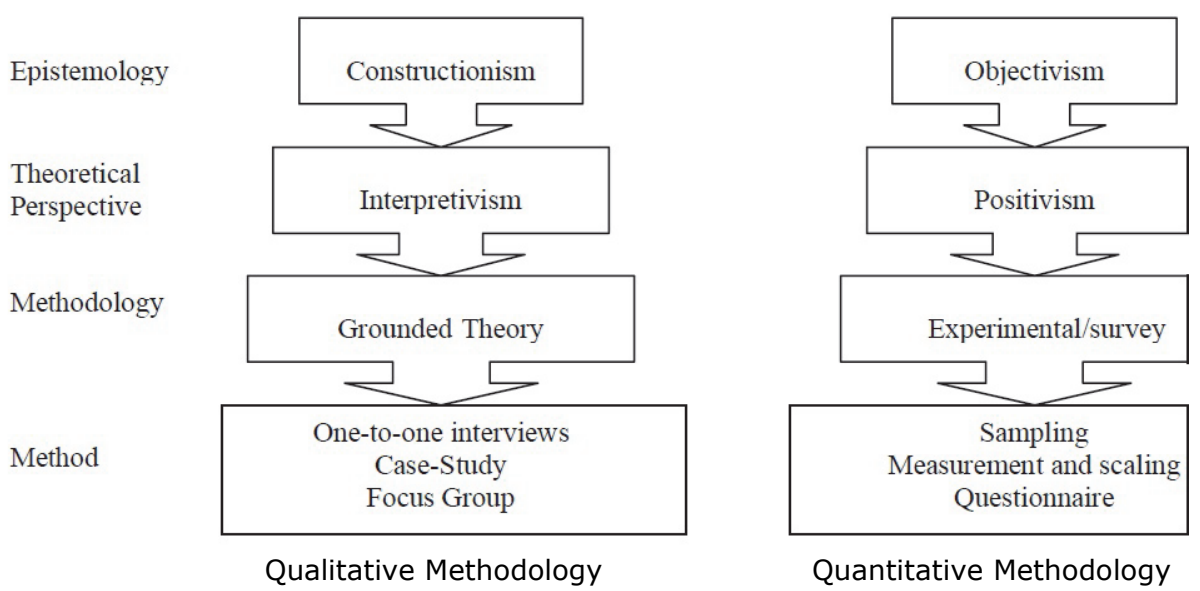

Figure 1.4: The four elements of the research design relating to a qualitative methodology and a quantitative methodology, source Levy (2006) adopted from (Crotty, 1998)

When the overview of the elements of the research design relating to qualitative and quantitative methodology is applied to the topic under examination in this research, it clearly points out that qualitative methodology is the appropriate methodology to be used in order to achieve the set of objectives within this research.

Strategies of doing a research in the domain of applied sciences include: experiments, surveys, histories, analyses of archival information and case studies. Yin (2003) discusses that the research strategy largely depends on the following three conditions: (a) the type of the research question, (b) the control an investigator has over the actual behaviour events and (c) the focus on contemporary as opposed to historical phenomena. Here follows a table where an overview of the strategies is made against the three conditions: 
Table 1.1: Relevant situations for different strategies (source: COSMOS incorporated in Yin (2003))

\begin{tabular}{l|c|c|c}
\multicolumn{1}{c|}{ Strategy } & $\begin{array}{c}\text { Form of } \\
\text { Research Question }\end{array}$ & $\begin{array}{c}\text { Requires Control of } \\
\text { Behavioral Events? }\end{array}$ & $\begin{array}{c}\text { Focuses on } \\
\text { Contemporary Events? }\end{array}$ \\
\hline Experiment & how, why? & Yes & Yes \\
\hline Survey & $\begin{array}{c}\text { who, what, where, } \\
\text { how many, } \\
\text { how much? }\end{array}$ & No & Yes \\
\hline $\begin{array}{l}\text { Archival } \\
\text { analysis }\end{array}$ & $\begin{array}{c}\text { who, what, where, } \\
\text { how many, } \\
\text { how much? }\end{array}$ & No & Yes/No \\
\hline History & how, why? & No & No \\
\hline Case study & how, why? & No & Yes
\end{tabular}

Having this overview, we could conclude that the case study strategies are used when 'how' and 'why' questions are posed, with little or no control over the event, and the phenomenon that is explored is contemporary. This fully reflects to the main research objective and posed research question, control over the event/phenomenon and the contemporary type of our research.

Yin (2003) defines a case study as an empirical inquiry that investigates a contemporary phenomenon within its real-life context, especially when the boundaries between phenomenon and the context are not clearly evident. Such methodologies are well suited to the investigation on the interaction between the phenomena in the real-life contexts. The use of case studies is also appropriate for descriptive studies in which the goal is to describe features, context and processes of a particular phenomenon (Yin, 2003).

Usually the intention of the researcher doing a case study research is to declare the results from the case study of a more general validity. This process is often called the process of generalisation. The findings or results from the single study are to follow a process of analytic generalisation, where case studies results are generalisable to theoretical propositions. Analytical generalisation is recommended for multiple case studies - observing the same phenomena in different cases (Yin, 2010).

To strengthen the relevance of analytical generalisation, it is important to make the right selection of the case(s) to be studied. If the aim is to make analytical generalisation possible, the selection of the cases can be seen as a dominant factor (Hutjes and van Buuren, 1992). The reasoning behind the sample of cases that is chosen can be based on one of the following strategies: 
- extreme cases,

- typical cases,

- maximum variance,

- minimum variance;

- critical cases (Hutjes and van Buuren, 1992).

In a comparable listing Swanborn includes the selection of cases that are in a different phase of development (Zevenbergen (2002) quoting Swanborn (1994)).

From the review of the doctoral researches in the area of the land administration reveals that nine out of ten doctoral dissertations preferred qualitative methods. Qualitative research is more appropriate for researchers who aim to explore and understand the nature of a phenomenon being studied (Cagdas and Stubkjaer, 2009). All ten dissertations were performed via case studies; nine used multiple case studies and one used a single case study.

After it was identified that the most appropriate methodology for this research would be qualitative methodology executed via suitable case study strategy, the next logical step would be to develop a research design model, containing a case study design and a selection of the areas for the main case studies.

\subsection{Research design model, case study selection and data collection}

In order to achieve the proposed main research objective and the subobjectives, appropriate in-depth explorations, and analyses of the research phenomena in the selected main case studies and supportive case studies should be performed. Based on the selection criteria main case studies are to be selected and then the focus groups are to be identified. This means relevant authorities and adequate employees within the focus groups are to be recognized in order to perform appropriate data and information collection. Another method of data collection in main case studies would be via one-to-one interviews. One-to-one interviews would have a set of general questions in a structured questionnaire but also specific set of questions prepared for the specific member chosen for the interviews. This would provide data and information from multiple sources of the particular main case study area.

Another input for this research would be the available literature from other countries, supportive case studies which also meet and reflect the previously mentioned characteristics of post-conflict contexts. These supportive cases 
would be used as lessons learned and how particular situations were overcome. The following figure gives the outline of the research design model:

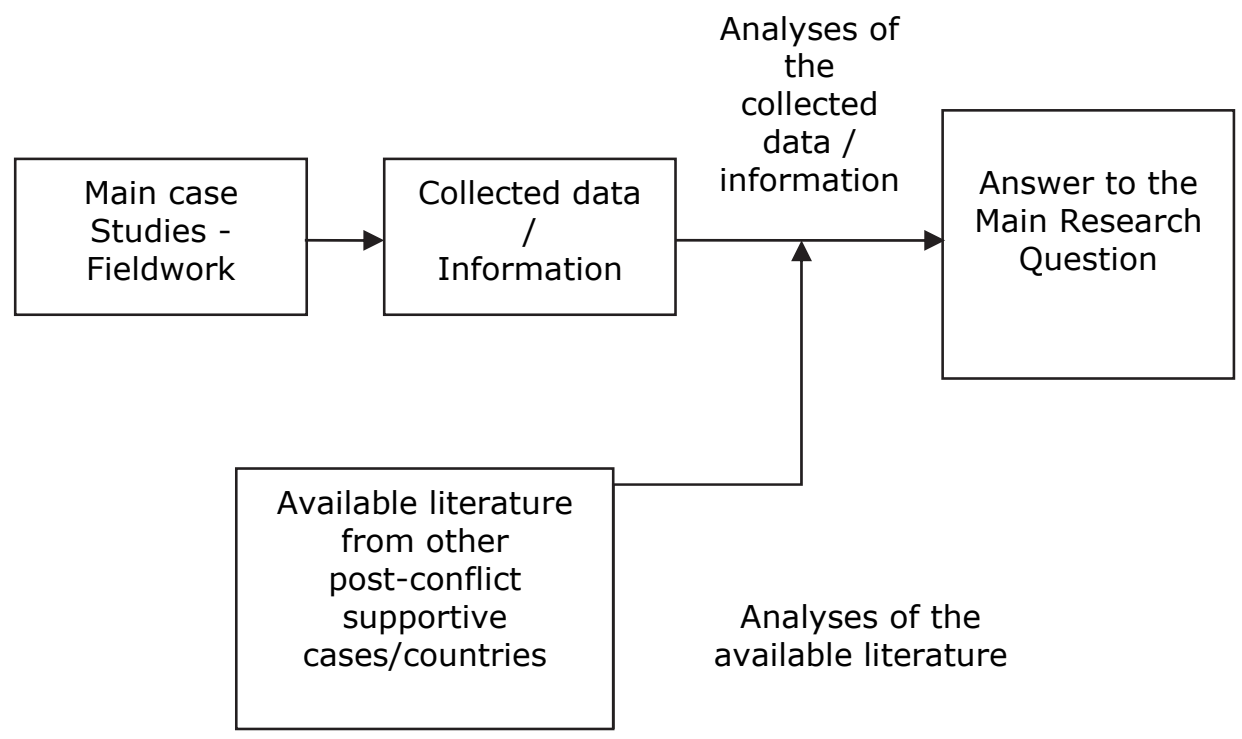

Figure 1.5: Outline of the research design model

Selection of the main case studies is based on the selection criteria where previously mentioned characteristics of the post-conflict contexts, land administration in post-conflict contexts and post-conflict state building are present in the selected cases. As a selection strategy, a strategy of the maximum variance is chosen which also includes variety of phase development of the phenomenon that is explored. In order to accomplish the choice of case studies that have maximum variance or are differently enough the following four characteristics are identified:

- $\quad$ About the post-conflict contexts in the main case studies characteristics like issues related to (1) refugees and IDPs should be present.

- Concerning land administration in post-conflict contexts in the main case study areas the characteristics like (2) land administration systems with or without land records and (3) presence or absence of land professionals should be present.

- Regarding the subject of post-conflict state building in the main case studies characteristics like (4) a newly-formed state after the conflict and the existing one coming out of the conflict should be present. 
From the abovementioned characteristics of the main pillars of the research topic we can extract a criteria model for case study selection:

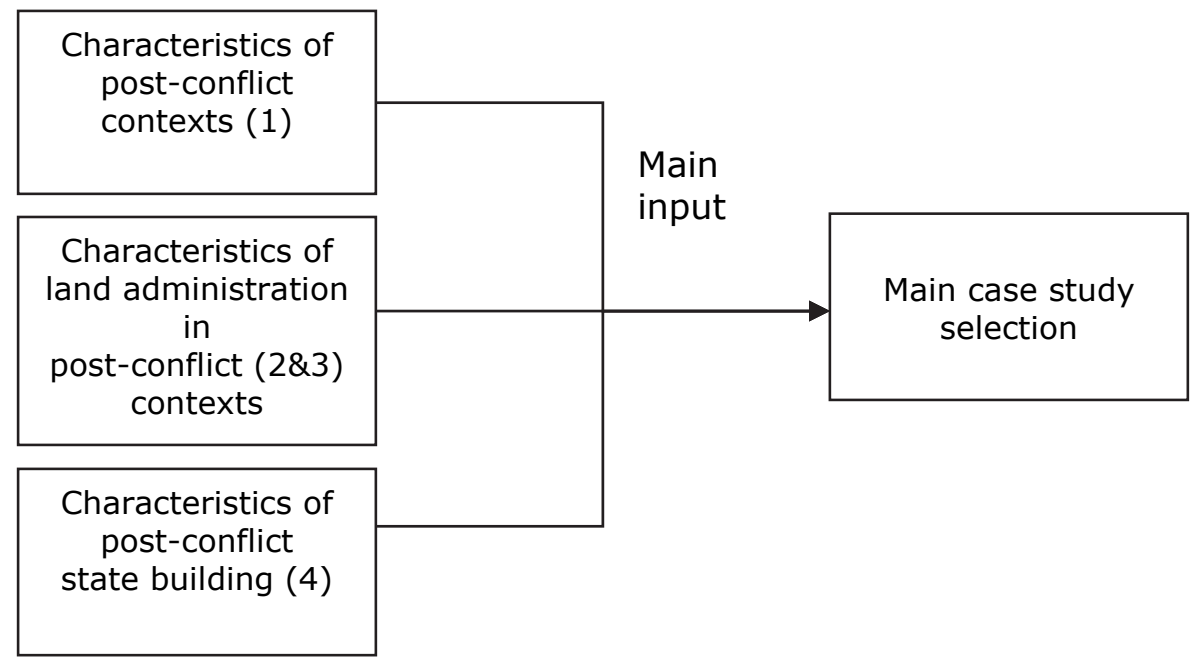

Figure 1.6: Criteria model for case study selection

Based on the literature review, previously mentioned characteristics for the case studies are identified and the following two case study areas are proposed to be selected: Kosovo (Meha, 2004; UN-HABITAT, 2003) and Rwanda (Rurangwa, 2004). Kosovo is a newly-formed state after a conflict and Rwanda is a state in which there was a long-lasting conflict, and both case studies have a variety of the other previously mentioned characteristics of the post-conflict contexts, land administration in post-conflict contexts and post-conflict state building. It is expected that from these two highly different cases enough data would be collected in order to give an answer to the Main Research Question.

Concerning the data/information collection from the chosen main case studies, here follows a model for proposed data collection: 


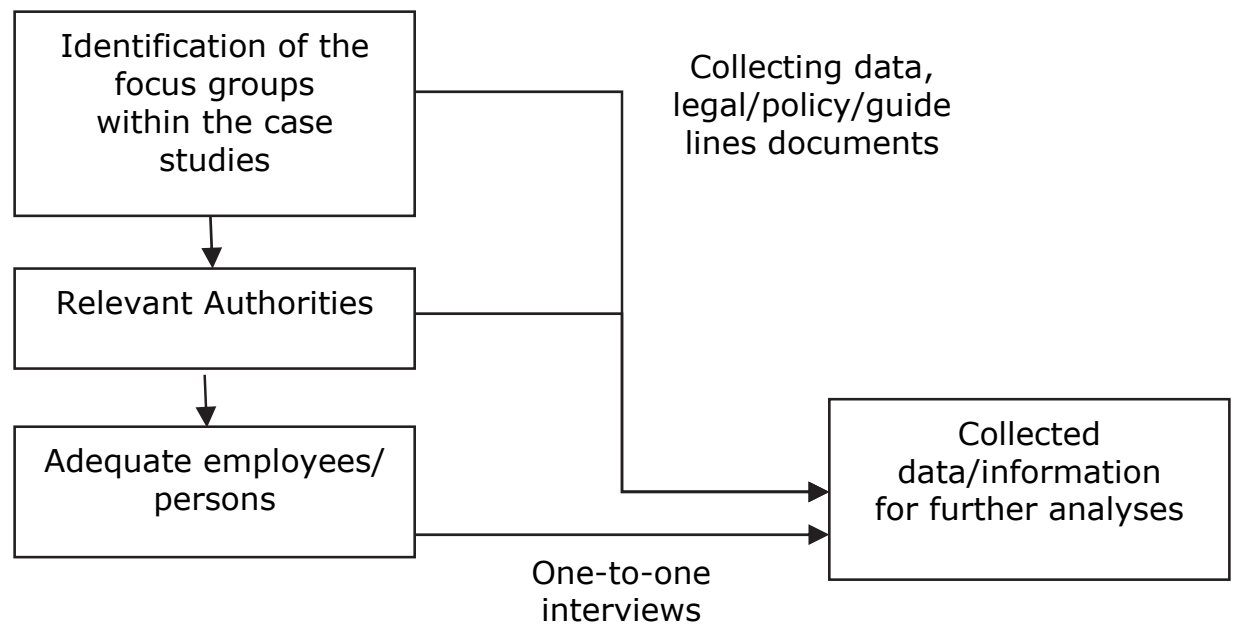

Figure 1.7: Proposed model for data collection

For the purposes of data collection for the main case studies, a fieldwork was performed in Kosovo in order to perform one-to-one interviews with the national and international experts in land. During this fieldwork, primary data were collected in interviews with relevant local (9) and international (6) professionals involved in the land sector in Kosovo, and secondary data were collected from various organisations dealing with land issues. Collected data and information from the one-to-one interviews regarding the first main case study - Kosovo are summarised in: Approved minutes from the interviews; Fieldwork report from the interviews; and Report from Skype interviews, personal communication and reports received from international experts (Todorovski, 2013a; 2013b; 2013c).

For the second main case study - Rwanda, data collection was executed in three separate fieldwork activities (Manirakiza, 2014; Potel, 2014; Songo, 2014). These fieldwork activities were realised in close collaboration, where, the author of this research was a PhD advisor and daily supervisor to the three MSc research projects. Selected locations in Eastern Rwanda for data collection were: Gasabo district (first fieldwork), Kayonza and Ngoma district (second fieldwork), and Rukara and Gahini sectors in Kayonza district (third fieldwork). Graphical representation of the selected study areas in Eastern Rwanda and the structure for selection of the interviewed informants are available in the Appendix of this research.

After the results from the main case studies were collected and analysed they were interpreted through so-called analytic generalisation, where case studies were generalisable to theoretical propositions. 
As supportive cases which were analysed via literature review and which also contain the characteristics mentioned, countries like Mozambique (Myers, 1994), Cambodia (Anttonen, 2006) and Timor-Leste (Fitzpatrick, 2002) were chosen.

\subsection{Thesis outline}

This thesis consists of six chapters. This chapter discussed the introduction of the research, gives the research objectives and other basic concepts that support the remaining chapters on the research. Here follows a structure of the research:

Chapter two - this chapter is devoted to understanding the characteristics of conflicts and post-conflict contexts in relation to land issues based on the literature review. Initially conflict and post-conflict contexts are explored in general. Identifying that land and land-related issues play specific role in such circumstances, the chapter continues with exploring more in depth the link between conflict and post-conflict contexts and land -related issues. Thus, land administration in post-conflict contexts is explored based on the available literature as well.

Chapter three - focuses on identifying the interventions in land administration which occurred in period before and during the conflict, and in the different phases of post-conflict period. The case of Kosovo is used to identify these interventions, and how they influence the conflict and postconflict contexts. The impact of the identified intervention in land administration suggests that they could be seen as elements of post-conflict state building. Therefore, these interventions are observed within the framework for rebuilding post-conflict states adopted from Ball (2001).

Chapter four - this chapter focuses on recognizing the characteristics of post-conflict state building, with a specific focus on HLP and land administration. The case study of Rwanda provides evidence about developments of post-conflict state building regarding interventions in land administration in post-conflict contexts. Findings from the analyses of results from this case study suggest that these interventions supported mainly institutional weaknesses and social and economic problems and to some degree the third characteristic of Ball's (2001) concept, security problems.

Chapter five - this chapter first explores the available literature to learn more about the concepts of state building, and the relation to land and its administration in post-conflict contexts. In continues by presenting the findings from the main case studies of Kosovo and Rwanda, and this is supported with presenting the findings from the supportive case studies of Mozambique, Cambodia and Timor-Leste. For analyses of the collected data a 
three-dimensional matrix has been generated, which supported by the findings from our cases results in analytical generalisation of the relation. Discussions and analyses of collected evidence indicate how interventions in land administration facilitate post-conflict state building.

Chapter six - this final chapter gives conclusions and recommendations for the entire research. The conclusive chapter is structured using specific research objective of this research provided in this chapter. In addition it presents a contribution to knowledge, policy makers and practitioners. At the end it provides recommendations for further research. 


\section{Chapter 2}

\section{Characteristics of conflict and post-conflict contexts in relation to land ${ }^{\star}$}

* This chapter is an extended version of a journal paper published as:

Todorovski, D., Zevenbergen, J. and van der Molen, P., (2015). Conflict and postconflict contexts in relation to land, other resources and land administration. In: Micro Macro \& Mezzo Geo Information, 5(2015), pp. 45-63. 


\begin{abstract}
Conflict and land are tied in a complex relation. This relation has various characteristics before, during the armed conflict, and in post-conflict contexts. Land and other resources are many times seen as factors for eruption of violent conflicts, in some circumstances influence the duration and give specific characteristics to the conflict. Land issues play a particular role in the post-conflict contexts. Land was identified as a critical gap in international response capacities and the awareness about the vital importance of addressing the housing, land and property issues within the context of post-conflict state building has increased. This chapter, based on the literature review, explores the characteristics of conflicts and post-conflict contexts in general, and specifically in relation to land, other resources and land administration. At the end, this chapter acknowledges the importance of land and its administration in post-conflict contexts as one of the essential elements in the process of post-conflict state building.
\end{abstract}

\title{
2.1 Introduction
}

Causes of violent conflicts are many and varied; in some cases land is a major cause. Land was identified as a critical gap in international response capacities (OCHA, 2005). Awareness about the importance of addressing the housing, land and property (HLP) issues in the emergency and early recovery period has increased in the last 15 years. On the other hand, experiences show that there are only a few cases where land issues were appropriately addressed in the post-conflict contexts. Humanitarian organisations in this period mainly focused on IDPs, refugees and restoring the situation as it was before the conflict.

There is increasing quantity of literature about the topic of land issues in post-conflict context, basically on what to do about land, land management and land administration in post-conflict contexts (EU-UN, 2012; FAO, 2005; Pantuliano, 2009; UN-HABITAT, 2007, 2009). Although the awareness of the importance of land and other resources in post-conflict contexts has increased within the international community, actors involved with the topic are underlining the need that more in-depth research in this specific area is required which should be evidence-based.

Recognizing the important role that land is playing within the conflict and post-conflict contexts is in line of the goal of this research chapter: to increase the understanding about the conflict and post-conflict contexts in relation to land, other resources and land administration.

The chapter starts with identifying the characteristics of conflicts and postconflict contexts. It continues with exploring the role of land, other resources 
and land administration in conflict and post-conflict contexts. It ends with conclusions about the main characteristics of the conflict and post conflict contexts in relation to land, and about the potential that land administration has for post-conflict contexts.

\subsection{Characteristics of conflict and post-conflict contexts}

Some researchers consider that conflicts in the world affect poor countries and that poverty is the strongest predictor of conflicts and wars (Daudelin, 2003). On the other hand recent events in countries affected by the so-called 'Arab Spring' and, for example, radical movements show that not only poverty but issues like authoritarian regime states, demographic structural factors, climate change, terrorism, human rights violation etc., also influence eruption of violence. In the rest of this section, characteristics of the conflict and post-conflict contexts will be discussed.

\section{Conflicts}

The basic idea of conflict can be described as a disagreement between people or groups about something, involving some degree of antagonism. Related concepts are dispute, contestation, contention, competition, rivalry etc. How people react to the disagreement or the intensity of the reaction to the disagreement leads to non-violent or violent conflicts. Non-violent could be latent or manifest conflicts, and violent conflicts could be crises, severe crises or war (HIICR, 2005). In the rest of this sub-section we explore and discuss the basic characteristics of armed conflicts.

Definition of an armed conflict: The most frequently used definition in the literature about an armed conflict is 'an armed conflict is a contested incompatibility which concerns government and/or territory where the use of armed forces between two parties, of which at least one is the government of a state, results in at least 25 battle-related deaths' (Wallensteen and Sollenberg, 2001). Because this chapter focuses on the armed conflict and situations in post-conflict contexts, the definition from Wallensteen and Sollenberg (2001) is chosen as a working definition. Other definitions that appear in the literature related to this topic are the definitions of land conflict (Wehrmann, 2005), and of secondary conflicts (Lewis, 2004; McAuslan, 2007).

Causes of armed conflicts: In respect to the causes of armed conflict Singer (1996) points out that 'the usual suspects' are to be found in territory, ideology, dynastic legitimacy, religion, language, ethnicity, selfdetermination, resources, markets, dominance, equality, and of course, 
revenge (quoted in Heinz-Jürgen et al. (2006)). Lewis (2004) discusses that wars in the last decades have been driven by long-simmering ethnic and religious ideologies and fuelled by a struggle for political and economic control.

When observing historically, wars were fought over land. In some cases land was one of the factors and sometimes land was a major cause for the conflict. Therefore, Putzel (2009) argues that the cause of a conflict is not the land only, but it always has a land dimension. Land is often a significant factor for widespread violence and also a critical element in peace-building and reconstruction in post-conflict situations (USAID, 2005).

Preventing armed conflicts: Many times in history world and national leaders have sought to avoid wars by taking steps to discourage the use of armed forces as an option for settling disputes (Lund, 1996). A central purpose of the United Nations (UN) was to 'save succeeding generations from the scourge of war' by 'effective collective measures for the prevention and removal of threats to peace' (UN, 2012). Not only via the Security Council but also through its functional agencies, development programs and associated economic agreements, the UN system was created to play a role of conflict preventer. The report by Secretary-General Boutros Boutros-Ghali 'Agenda for Peace' UN (1992) devoted a chapter to preventive diplomacy and received positive endorsements from the UN General Assembly in October 1992. Since then the UN Secretariat has been reconstructed to encourage ongoing monitoring of potential humanitarian crises and its three main units are: humanitarian affairs, political affairs and peace-keeping.

The Organisation of Security and Cooperation in Europe (OSCE) committed in their 1990 Charter of Paris for New Europe (OSCE, 1990) to 'seek effective ways of preventing, through political means, conflicts which may yet emerge'. There is a special issue on Land and Conflicts in the Toolkit and guidance for preventing and managing land and natural resources conflicts (EU-UN, 2012). The voluntary guideline of FAO (FAO-VG, 2012) acknowledges that 'all parties should take steps to prevent and eliminate issues of tenure of land, fisheries and forests as a cause of conflict and should ensure that aspects of tenure are addressed before, during and after the conflict'. To summarize, although a great deal of pessimism prevails regarding the efficiency of international involvement in regional conflicts, the post-Cold War era has also seen an unprecedented burst of interest and activity devoted to addressing such conflicts before they become a crisis (Lund, 1996).

The changing nature of conflicts: From the mid-twentieth century onwards, the nature of armed conflicts has changed; conflicts have moved 
inside national boundaries and civil wars and insurgencies are much more common today than wars between states. Instead of involving different countries, armed conflicts are more frequently involving governments and opposition groups, and they occur in regions where people depend on land and natural resources for their living (Unruh and Williams, 2013a). From the forty ongoing conflicts in 2014, eleven conflicts generated 1.000 or more battle-related deaths in one calendar year, only one was interstate and thirteen were internationalised internal armed conflicts (Themnér and Wallensteen, 2015). Looking at the conflicts that occur in the period 19902009 land-related issues played a substantial role (Alden Wily, 2009). The most serious concerns emerging from the armed conflicts are casualties, destroyed infrastructure and houses and displaced population. In those cases displacement is becoming an alarming issue for the states in conflict, the neighbouring states, the UN and the international community (Hollingsworth, 2014; Takeuchi et al., 2014).

The number of people killed in the conflict: While wars today seem to kill fewer people than past conflicts, what is remarkable is that a greater numbers of civilians appear to be exposed and vulnerable to violence (UNHCR, 2012). The proportion of all war casualties that were civilian increased from about $14 \%$ in the First World War to $67 \%$ the Second World War, and to $90 \%$ in the 1990 s (B. Levy and Sidel, 1997).

Refugees and IDPs: One of the characteristics of conflicts in the last decades is the enormous number of displaced people. The UN estimates that there were approximately 51.2 million forcibly displaced people worldwide as a result of prosecution, conflict, generalised violence, or human rights violation by the end of 2013 (UNHCR, 2014). This figure includes 16.7 million refugees (population displaced in the neighbouring or third party countries), 33.3 million IDPs and 1.2 million asylum-seekers.

Destroyed housing and infrastructure: Widespread destruction of houses and infrastructure are very common scene of conflict and in post-conflict contexts. In the case of Kosovo, OSCE and the UN-HABITAT estimated 103,000 housing units, half of which were destroyed and the other half damaged, representing more than forty percent of available housing units (Valstad, 2004). The violent conflict in Timor-Leste, in the period 1975-1999, witnessed a violation of human rights, an estimate of 100.000 people that were killed during the conflict, several waves of displacement of the population in large numbers occurred and widespread destruction of houses and infrastructure (CAVR, 2005). The destruction of houses and infrastructure has an influence on the number of people killed during the conflict and they are one of the reasons for displacement of population. 
The peace agreement document: Armed conflicts usually end with the signing of a peace agreement described as: 'a formal agreement between warring parties, which addresses disputed incompatibility, either by settling all or part of it, or by clearly outlining a process for how the warring parties plan to regulate the incompatibility' (UU-DPCR, 2012). Experiences show that land issues are not always included in the peace agreements. Some developments regarding this are evident as: 'land issues may be included in peace negotiations and agreements and UN peace missions' or 'land is seen as too politically sensitive or too technically complicated to lend itself in the meaningful resolution: as experience has demonstrated, this is mistake' (EU-UN, 2012). De Wit in the HPG (2008) underlines that there is a need to ensure land issues are tackled in peace agreements and that this includes an adequate follow-up. The issue of including HLP rights in peace agreements should be stimulated since it could compromise an often fragile peace. Nevertheless, making references to land can be important (even in fragile contexts) as it puts pressure on the issue not to be dropped off the political agenda.

\section{Post-conflict contexts}

After armed conflicts sometimes a new state is formed or the old one is coming out of the conflict; in both cases a post-conflict state building process should follow. The first challenge that these states are facing is the peace keeping process. According to FAO (2005) the general characteristics of the post-conflict environment are death and injury, hunger and starvation, displacement of people, negative social and psychological consequences, changes in values and expectations, destruction of infrastructure and housing, limited government capacity, limited funding and limited national 'ownership' of recovery plans. McAuslan (2007) argues that in an immediate post-conflict situation, governmental institutions are weak, trust both in government and between people and communities are absent. Therefore adequate policies and measures should be developed and implemented to overcome this situation. Discussing the rebuilding of post-conflict situations, Ball (2001) distinguishes thee main characteristics of war-torn societies: institutional weaknesses, economic and social problems, and serious security problems.

Phases of post-conflict period: The post-conflict period starts when the main hostilities have ceased, some kind of peace agreement is signed and international assistance can be provided. This period generally distinguishes three phases: emergency, early recovery and reconstruction. Some scholars observe post-conflict phases based on time (Maier, 2010) and others based on activities undertaken (FAO, 2005). Activities in the emergency phase typically focus on the establishment of basic governance and the provision of 
humanitarian services. Activities in the early recovery could be identified as the development of policies, strategies and legal frameworks, the establishment of government and administrative infrastructures, and the development of interim and long-term policies. The reconstruction phase is characterized by the implementation of those policies, strategies and laws from the early recovery phase. The phases should not be understood as absolute, fixed, time-bound or having clear boundaries, but are contextually determined (FAO, 2005; NEPAD, 2005). The post-conflict period is complex, fluid and enormously difficult.

Refugees and IDPs after the conflict: Sometimes people during the conflict experience forced eviction. Displaced people often settle on land to which they have no legal claim. There is also an issue that remaining citizens occupy land and houses left by refugees/IDPs: this type of occupation is called secondary occupation. There is an important legal distinction between refugees and IDPs. Refugees are people who flee their homes for the safety of another country. IDPs are people who flee from violence but remain within their own country (FAO, 2005). The right of all refugees and IDPs to return to their homes and places of habitual residence in their country and/or place of origin is defined in relevant international legal instruments (UN, 1998). The period after the end of a conflict is critical because of the possibility of the return of the displaced population in large numbers and in a short period of time, and this is when the land-related challenges arise on the horizon and a possibility for renewed violent conflict (UN, 1999c).

Displacement fosters urbanization: Sometimes IDPs and refugee camps become towns or suburbs of big cities and in many cases displaced persons cannot or do not want to go back to their original homes in the rural areas. In Mozambique for example, when displaced persons returned back to their original properties they found that their properties were occupied through secondary occupation by governmental staff, soldiers and military staff. Because of this, many returnees were located near infrastructure, markets and transportation but also a large number of them found shelter in the existing towns and cities (Myers, 1994). This is recognised as displacement fosters urbanisation. In this direction UNHCR in 2009 has recalibrated its operations towards urban areas, and adopted a new Policy on Refugee Protection and solutions in Urban Areas (UNHCR, 2012).

Humanitarian organisations: In the emergency phase of the post-conflict period the first people on the ground are actors from humanitarian organisations and from the International Community. These are usually logisticians and procurement people. De Waal discusses 'selective nostalgia': humanitarian agencies frequently try to 'return to the way things were', but these ideals are often unrealistic or even undesirable after processes of 
change and transition (de Waal, 2009). Pantuliano acknowledges that although awareness has increased, humanitarian organisations remain focused on returning land to IDPs and refugees rather than on wider structural issues and their effects on the population as a whole. There is a need to get to grips with the reality of change and how best to promote positive outcomes. There needs to be a shift from focusing solely on restitution to reform (Pantuliano, 2009). Activities undertaken in the emergency phase have an impact on the processes of peace and post-conflict state building in the long run.

Involvement of UN and international community: In the last two decades, the number of international post-conflict operations has substantially increased. These operations have proved to be complex and results have been mixed. Important policy lessons are beginning to be learned, e.g. that policies are most effective when they are integrated, striking the right balance between security, governance and socio-economic development (Anten, 2009). The increased involvement of international organisations may have a double effect. The weakening or destruction of domestic institutions caused by conflict increase the need for international assistance. More international involvement in modern conflicts may then have a beneficial effect. The downside of international involvement is dependency. If project programmes are installed and maintained by international actors, they can easily collapse as soon as the latter leave the arena (Belloni, 2001). Either the international organisations should finish the process of rebuilding war-torn societies before they leave, or the system of settlement and enforcement should be firmly rooted in local systems, making it independent of international presence as far as possible (Buyse, 2008).

\subsection{Land and other resources in conflict and post- conflict contexts}

As described in UN/ECE (2005) land can be recognized as a source of all wealth. Land is a place of all shelter, in the city, the town, the village, and at home. It is the source of food, of materials for construction and manufacture, of coal, gas and oil, of springs and rivers and other essentials for life. Indestructible, immovable, it is the foundation of all human activities. Houses and factories, forests and farms, river roads and railways, mines, quarries, and reservoirs are all fashioned from the land. It offers endless opportunities for development and discovery. From a land administration perspective 'Land' is to be considered as the surface of the earth, the materials beneath, the air above, and all things fixed to the soil, so it is more than just 'land' alone: it includes buildings, etc. (van der Molen, 2002). 'Recognizing that land is a source of wealth lies at the heart of good government and effective public administration' (UN/ECE, 2005). 
The role of land and other resources, natural resources for example, in conflict and post-conflict period is attracting international attention. Land and natural resources often contribute to conflict and are affected by conflict (Unruh and Williams, 2013a). The changing nature of violent conflicts combined with long-term demographic, economic and environmental trends present significant practical challenges for global peace and security (EU-UN, 2012). In this chapter first natural resources are observed in regards of their impact on the eruption of conflicts, during the conflict and their role in the post-conflict period, then land issues and land administration in the conflict and post-conflict period are explored more in-depth.

\section{Natural and other resources in conflict and post-conflict contexts}

Since the late 1990s, many scholars have studied the relationship between natural resource wealth and conflicts. Most have been motivated by a series of high-profile conflicts - cases like Angola, Colombia, the Democratic Republic of Congo, Liberia, Sierra Leone, and Sudan - that have captured the attention of both international organisations and the media. These studies tell us about the relationship between natural resources - including oil, gas, nonfuel minerals, gemstones, narcotics, timber, and agricultural products - and violent conflict (Ross, 2004).

Resources not only financed, but in some cases motivated conflicts, and shaped strategies of power based on the commercialization of armed conflict and the territory of sovereignty around valuable resource areas and trading networks. Natural resources have played a conspicuous role in the history of armed conflicts (Le Billon, 2001). From competition over wild game to merchant capital and imperialist wars over precious minerals, natural resources have motivated or financed the violent activities of many different types of belligerents (Westing, 1986).

Armed conflicts and natural resources can be directly related in two main ways: armed conflicts motivated by the control of resources, and resources integrated into the financing of armed conflicts. Although few wars are initially motivated by conflict over the control of resources, many integrate resources into their political economy. Beyond motivating or financing conflicts, the level of dependence, conflictuality, and lootability of a resource can also increase the vulnerability of societies and the risk of armed conflict (Le Billon, 2001).

Several case studies from African (and Central Asian) civil wars have shown the complex political economy of resource exploitation, armed struggle and oligopolistic regimes of resource exploitation, especially when high-value resources such as oil or diamonds are available (Korf and Funfgeld, 2006). 
Ross (2004) analysed the following five resource-conflict relationships:

- whether or not natural resources influence the onset of conflict;

- whether or not resources influence the duration of conflict;

- whether resources influence all types of civil wars or only a subtype, e.g. ethnic or separatist conflicts;

- whether all types of resources, or only a subset (e.g. oil, diamonds) are linked to conflict; and

- what causal mechanisms link resources to conflict.

He used the results from research collected in the period of five years; the weight of the evidence available so far suggests four regularities:

(1) oil dependence appears to be linked to the initiation of conflict, but not to conflict duration; there is some evidence that oil dependence (and possibly mineral dependence) is more strongly associated with separatist conflicts than other types of conflicts;

(2) gemstones, opium, coca, and cannabis do not seem to be linked to the initiation of conflict, but they do seem to lengthen pre-existing wars, the role of timber remains untested;

(3) there is no statistical evidence - and very little case study evidence that links agricultural commodities to either the initiation or the duration of a civil war;

(4) the claim that primary commodities are associated with the onset of civil war does not appear to be robust.

Ross (2004) argues that research on resources and conflict has developed remarkably fast; almost all of the studies described here have been carried out since the 1998 publication of Collier \& Hoeffler's seminal article. Collier and Heoffler (1998) investigated whether conflicts have an economic cause in a utility model with four variables: initial income, ethno-linguistic fractionalisation, the amount of natural resources, and initial population size. Recommendation at the end is that if scholars wish to produce research that contributes to better policies, they must think carefully about testing their ideas, sharing data, speaking a common conceptual language and drawing together the findings of disparate research projects - both qualitative and quantitative.

Recent studies have shown that conflicts associated with natural resources are twice as likely to relapse into conflict within first five years after the end of hostilities (UNEP, 2009).

To summarize, natural resources can have influence, as a cause of conflict, on the duration of the conflict; they play specific role in the post-conflict 
period. If adequately managed, they could contribute to the post-conflict economic development of the particular state and to the overall post-conflict state building.

Resource scarcity as a risk factor for possible violence/conflict: According to advocates of the scarce resource wars hypothesis, people or nations will fight each other to secure access to the resources necessary for their survival: the more scarce the resource, the more bitter the fight (Homer-Dixon, 1999; Peluso and Watts, 2001).

The link between scarce resources and conflict is contested in general (de Soysa, 2002). Several scholars argue that scarce resources should be more relevant in generating smaller more local conflicts than civil or intrastate wars (Barnett, 2001). The researchers in this field developed a Malthusian concept or frame by linking resource scarcity with violence (Korf and Funfgeld, 2006).

In the literature on the nexus of resources and violent conflict, two broad lines of thinking can be distinguished. Both have in common that they essentialize a kind of resource curse. The first one works in a neo-Malthusian conception that links population growth with increasing resource scarcity and related environmental problems, which translates into triggers for violent conflict (Homer-Dixon, 1999). The second school of thought links violent conflict with resource abundance rather than scarcity. This argument stresses the opportunities to monopolize resource rents through violence in 'greed driven' warfare (Collier, 2000).

Effects of 'Climate Change' and conflicts: The phenomenon of climate change has been researched with focus on how it could be related with violent conflicts. The evidence of the coming climate change has generated catastrophe-like statements of a future where a warmer, wetter, and wilder climate leads to a surge in migrant streams and gives rise to new wars (Theisen, 2012).

Statements like: 'the threat from climate change is serious, it is urgent, and it is growing. More frequent drought and crop failures breed hunger and conflict are expected' (Obama, 2009) but also many scholars (e.g. (de Soysa, 2002; Peluso and Watts, 2001) with their arguments posit a clear link between resource scarcity and conflict. Effects expected from the climate change could be draughts, floods and more disasters caused by nature.

Research in this area proved that climatic factors do influence the risk of conflicts and violent events. Research performed by Theisen (2012) comes to findings which indicate that relatively dry years tend to have a peaceful effect on the following year. Little support is found for the notion that scarcity of 
farmland fuels violence in itself or in election years, but an election by itself increases risk. More densely populated areas run a higher risk of conflict, but this is not due to pressure on cropland; rather, it is likely to be driven by other mechanisms that put densely populated areas at risk. Taking a longerterm perspective, Witsenburg and Adano (2009) analyse the Marsabit district in Kenya and find that wetter years see on average more than twice as many killed than drier years do.

Theisen's summary of the result from his research is the following: climatic factors do influence the risk of conflict and conflict events, quite strong evidence for years following wetter years being less safe than drier years, the thesis that land scarcity breeds violence in itself and in election years receives little support, although population density per se is found to increase conflict risk. Other factors that influence conflict are political marginalization (spill over of civil conflicts, or hideouts for criminal elements) and ethnics manipulation (Theisen, 2012).

The point in the summary is that natural and other resources are key to the 'sustainability' of violent conflicts (Daudelin, 2003).

In the above parts of this sub-section an overview was performed on the existing literature on the relation of conflict and post-conflict contexts in relation to natural and other resources, with aim to identify their implications on land administration. It showed that this relation do not has strong implications on land administration in conflict and post-conflict contexts.

\section{Land issues in conflict and post-conflict contexts}

During a conflict people are killed, infrastructure and houses are destroyed and masses of people are being displaced. Destruction and displacement have a great influence on land and property related issues during and specifically in the aftermath of the conflict (Hollingsworth, 2014).

One of the immediate and frequent land-related problems in post-conflict contexts, leading to confusion as regards variety of legal and administrative issues is legal ambiguity. Usually the following situations are present here: unclear rights of access and use of land and properties, confusion about which institutions govern land, disputes related to individual ownership and land, and overlapping, incomplete, inconsistent and outdated land policies (Unruh and Williams, 2013a).

Legal pluralism is another feature of post-conflict contexts, here, different types of laws regulating ownership or rights to use land and property (including ad hoc, customary, religious, and statutory - often localized) 
coexist and function beside each other. Governmental capacities and structures are often weak and fragmented, as regards which ministry or authority has the mandate to enforce abovementioned laws. Establishing (or re-establishing) tenure security can be very complicated in countries emerging from years of conflict, especially where land records are not available or badly organised, and where statutory and customary systems overlap (Fitzpatrick, 2008).

A small number of professionals with background in land and property related issues are engaged in the topic of conflict, and are especially needed in postconflict contexts. This specific environment requires engagement of different actors to come and work together in the early stages of the post-conflict period. Pantuliano in HPG (2008), underlining the critical importance that land issues play in conflict and post-conflict contexts, stresses the identified need to bring land tenure expertise to the humanitarian community (HPG, 2008).

At the end of conflict, masses of displaced population return to their places of origin. With their return, a host of land-related problems arise and returning population usually face illegal occupation of their properties by local commanders, disputes arising from the loss and destruction of ownership documents, fraudulent transactions, land distribution by successive governments to their political supporters and disputes over grazing and water rights (Guterras, 2009).

Disputes over land are often an underlying cause of, and factor in, conflict, especially in protracted crises. Land dispute resolution mechanisms are viewed as a conditional tool for a good peace process as well (Unruh, 2001). It is important that land claims and grievances be addressed promptly at the end of a conflict. If these issues are overlooked, property disputes will inevitably escalate and may risk threatening the usually fragile stability of a post-conflict transition. The increase in land and property disputes in the post-conflict period usually stems from the failure to understand or constructively manage post-conflict land and property relations. This has important implications for return, recovery and reintegration processes (Pantuliano, 2009).

Daudelin (2003) developed an analytical framework that would help assess the correlation of land policies and conflicts. The framework addresses issues regarding the access to land, the security of tenure and distribution of land which are addressed within the particular land policy of one state. The conclusion from this research is that 'land policy can make things worse or better but it is only exceptionally a critical factor of conflict, even in the 
countries and societies where the vast majority of the population depends on agriculture for its survival, and even countries coming out of war'.

Despite increasing evidence that land is often a critical issue in conflictaffected emergencies and forced displacement and that it plays a key role in post-conflict reintegration and reconstruction processes, there is a perceived lack of humanitarian engagement on HLP issues. Emergency measures such as creation of IDP camps and other settlements are de facto interventions in land management and land tenure (de Waal, 2009). Acting on land issues in post-conflict contexts is of crucial importance in order to support a peaceful transition after the conflict. The management of land relations is intrinsically linked to a range of peace benefits (Cramer and Weeks, 2002).

Future about conflicts: When one looks to the future it is difficult to avoid the disturbing conclusion that the issue of land, conflict and humanitarian action will need a more prominent place on the international agenda. An accumulation of adverse trends - economic downturn, the process of climate change, volatile food and energy prices - appear likely to create the conditions for conflict within and between states, some of them directly related to the struggle for land, water and other scarce resources (Guterras, 2009).

\section{Land administration in post-conflict contexts}

The important role that land plays within the conflict and post-conflict period drives this research to explore the existing literature on how the land is managed and administered in these circumstances. That is the aim of this sub-section: to increase the understanding of the role of land administration in post-conflict contexts.

Land Administration: The term 'land administration' was introduced in the 1990 s and was probably given 'official' status by the UN/ECE Working Party on Land Administration (WPLA) for the first time in 1996 (Steudler, 2004). According to the UN/ECE website, the aim of WPLA is the promotion and improvement of land administration and land management by supporting security tenure, improving and creating more effective registers and promotion of sustainable land use policies (UN/ECE, 2015). The importance of effective land administration in support of good governance and economic development is well recognized internationally (Groot and van der Molen, 2000).

The UN/ECE Land Administration Guidelines defines land administration as 'the process of determining, recording and disseminating information about 
tenure, value and use of land when implementing land management policies' (UN/ECE, 1996).

Land administration deals with ownership, use and value of land (Zevenbergen, 2002). Cadastres have registered the human terrain for centuries (Batson, 2008). 'Ownership' is to be seen in a broad sense: as land tenure, which is the mode in which rights to land are held, based on statutory law, common law, and customary traditions. 'Value' is to be understood as all kinds of values which land might have, depending on the purpose of the valuation, the use of the land and the method of valuation. 'Land use' is to be understood as all the kinds of use land might have, depending on purpose and use, classification and methodology (van der Molen, 2002).

The definition for the land administration from UN/ECE (1996) has been used in many policy documents and research studies. In this research it is the key guiding principle as well.

Land administration in post-conflict contexts: The situation as regards housing and property rights and land administration in post-conflict contexts is difficult and multi-dimensional. Many of those conflicts have direct effect on the control over land and the rights of people relating to land and cause innumerable denials of HLP rights (Tibaijuka, 2007). Therefore, it is not possible to develop guidelines for all aspects for all countries and scenarios simultaneously, and addressing housing and property rights and land administration in such contexts requires an approach that copes with the local circumstances (van der Molen and Lemmen, 2004). Some of the land challenges that arise in post-conflict situations include loss or destruction of property, secondary occupation, landlessness, insecure use or mobility rights and lack of clarity regarding ownership or user rights (UN-HABITAT, 2007).

The immediate post-conflict period is very complex, when many displaced people return to their places of origin and find their houses and properties destroyed, damaged or illegally occupied by secondary occupants (Leckie, 2000). Land disputes and conflicts over land and properties are frequent problem in post-conflict contexts. Conflict-sensitive approaches to land dispute may vary based on factors such as the effectiveness of local and national land administration systems, the quality of land records, and the capacity of local administrators and adjudicators (UN-HABITAT, 2009).

Post-conflict situations lead to a dysfunctional land administration system characterised by limited prioritisation of land policy, discriminatory land law, poor institutional and regulatory framework that allowed the grabbing of public and private land by powerful individuals and groups, poor management information systems for updating records as well as weak state capacity that 
was incapable of helping internally displaced people and refugees (Augustinus and Barry, 2006). Addressing these fundamental challenges, dealing with land administration in post-conflict situations, is no longer a matter of choice, but a core responsibility of effective peace building. Once it is understood that HLP issues may trigger secondary or tertiary conflict, it is important for peace building missions to become aware that proposals related to land management and land administration in post-conflict situations are an integral part of efforts to restore peace and stability (UN-HABITAT, 2007).

What is needed is a post-conflict land policy which focuses on the political dynamics of the conflict over land. The policy should give guidelines about the land law and the technical dimensions of land administration. Land professionals with experiences in the development of land policy documents and with appropriate knowledge in post-conflict context could significantly contribute to this process (McAuslan, 2007).

The normative framework for addressing HLP rights in the context of displacement is summarised in the 2007 Principles on Housing and Property Restitution for Refugees and Displaced Persons (COHRE, 2007), known as 'Pinheiro Principles'. 'The Pinheiro Principles provide restitution practitioners, as well as states and UN and others agencies, with a consolidated text relating to the legal, policy, procedural, institutional and technical implementation mechanisms for housing and property restitution' (COHRE, 2007). This document is a compilation of existing rights-based documents in international human rights and humanitarian law. It acknowledges that all displaced persons should be protected regarding their HLP rights; the right(s) that they had to their property should be restored or if that is not possible be compensated. The Pinheiro Principles make some references to land administration issues as well (Pinheiro Principles: 13, 15, 16, 17, 20 and 21).

Housing, land and properties and land administration issues are always negatively affected by the conflict and if not addressed properly in a postconflict context they could be cause of secondary conflicts and even erupt into a new armed conflict (Todorovski et al., 2012b).

Land administration systems can suffer in several ways during a conflict. The most obvious blow follows from the loss of staff and records (Zevenbergen and Burns, 2010).

\section{Land professionals}

As said in Chapter 1, staff can be killed, (forced to) leave the area or not be able or willing to return to their jobs within land administration systems. In all cases it is important to quickly identify available experienced staff and try 
to get them back to work as soon as possible. Most land administration staff are professionals with specific expertise, and except for (top) managers their position should not be political, but this depends much on local circumstances (Zevenbergen and Burns, 2010).

Experiences show that too few of the engaged personnel in the emergency phase have appropriate knowledge and skills in land administration issues which have their specific characteristics and need adequate approach for land administration in post-conflict contexts (HPG, 2008; Pantuliano, 2009).

When -at the end of the day- a land registrar writes down a name of an owner in a land book, and a land surveyor draws a boundary line on a cadastral map, it could be either the start of a prosperous economic development, or the overture to a new conflict (van der Molen and Lemmen, 2004). The work of land registrars and land surveyors can be seen in a context of state and nation building (van der Molen, 2011).

\section{Land records}

Land records are the evidence of ownership and user rights. Land records are typically associated with formal land administration systems. In countries where land is administered through customary bodies, where formal legal systems are not accessible to significant parts of the population, records are kept locally and transactions recorded through simple sales contracts, witness statements or local knowledge and attribution (UN-HABITAT, 2009).

During conflicts and immediately thereafter land records face a number of threats. They run the risk of being damaged or even lost due the hostilities, due the random violence directed at government offices or even targeted violence to land offices. In all cases there is no (easy) access to the records. Land records can be simply ransacked or partly destroyed. Fully paper-based systems are even more vulnerable since no formal back-ups usually exist (Zevenbergen and Burns, 2010).

Examples of the status of land records in different post-conflict contexts are as follows:

Kosovo: land records were taken away by retreating authorities when they were forced to leave the area, with good or bad intentions (Zevenbergen and Burns, 2010);

Somalia: land registries for the valuable irrigated areas in the central part of the country have been largely destroyed and will lead to significant problems once a central government and peace prevail (Unruh, 2004); 
Burundi: many arrived to their villages of origin only to find their land and houses occupied by those they saw as responsible for the genocide and their exile; such persons had no reliable formal or informal system to regain their homes and lands and most were forced to return to the entry points at the border, where they were no longer eligible for food aid and household items, as they had not managed to establish themselves in their villages of origin (UN-HABITAT, 2009);

Palestine: a copy of Ottoman land records of the Palestine State rests in the UN building in New York (Zevenbergen and Burns, 2010);

Cambodia: During the Khmer Rouge era (1975-79) the state infrastructure was literally destroyed, for example, the land registration records were all lost (Törhönen, 2001);

Timor-Leste: the land and property building was among the first destroyed by militia activity along with most property rights records; the (Indonesian) head of the Dili land office took the main land books into safety during the violence in Timor-Leste (Fitzpatrick, 2002).

Some of the issues that need attention are finding and securing the land records that are (still) available and preventing illegal occupation and construction on the other land (Zevenbergen and van der Molen, 2004).

To summarize, the land records in post-conflict land administration contexts turn out to be a vulnerable subject and are always negatively affected during the conflict. Fully paper-based systems are even more vulnerable than digital ones, since no formal back-ups usually exist. Land records in post-conflict land administration contexts can be damaged, stolen, lost, facilitated or manipulated by parties (groups) in power, partly or fully destroyed, moved to a third country or even be a target for violent attack (Todorovski, 2011).

\section{Characteristics of land, other resources and land administration in conflict and post-conflict contexts}

The role of land and other resources in the conflict and post-conflict contexts is attracting international attention and it is a real practical challenge for global peace and security. Below are the findings regarding land, other resources and land administration in conflict and post-conflict contexts:

- resources in some cases motivate conflicts and usually support conflict financing; 
- conflicts related to natural resources are twice as likely to re-emerge in period of five years;

- scarce resource wars hypothesis: the more scarce the resource, the more bitter the fight, but the majority of the literature argues that scarce resources are more relevant in generating small local conflicts rather than civil or inter-state wars;

- effects from climate change could lead to more catastrophes caused naturally; research proved that climate change does influence the risk of conflicts and violent events;

- contrary to the theory of scarce resource wars hypothesis, a research on climate change shows that when resources are scarce then there are fewer conflicts - wetter years being less safe than dry years;

- as to resources it could be concluded that they are a key to the 'sustainability' of violence;

- refugees and IDPs are a common challenge in conflict and post-conflict contexts and together with this challenge land-related issues appear to be an urgent problem;

- land and property disputes and claims usually arise when displaced persons return, or from dominance struggle over land and property rights;

- land related topics that arise in post-conflict period are loss/destruction of properties, secondary occupations, landlessness, insecure land rights, lack of clear ownership or user rights, access to land, forced transactions, non-functional land administration systems, HLP rights etc.;

- UN-HABITAT (2007) underlines that addressing the fundamental landrelated challenges in post-conflict settings using the land administration as an instrument is a core responsibility of effective peace building;

- the normative framework for addressing HLP rights in the context of displacement are summarised in the 'Pinheiro Principles' (COHRE, 2007), which make a reference to land administration in several chapters. However, Potel et al. (2015) argues that that implementation of this framework depends a lot on post-conflict circumstances; the case of Rwanda showed that specifically the principles in regard of restitution of housing and property rights as before the conflict and restitution at any moment in post-conflict period (no time binding), were not applicable; 
- land administration systems in conflict and post-conflict period mostly suffer in areas of loss of staff and land records;

- historically land administration issues have not been figured prominently in UN emergency and peace building operations (only in the cases in Kosovo and Timor-Leste).

With a number of functions like support in establishment of land market, land use, setting the tax and management of state land, land administration in post-conflict is relevant and should be recognized in peace treaties. Parties involved in the formulation of peace agreements and/or strategic action plans should mention land registration not as an isolated objective but rather embedded in such plans for a wider development and land policy. Land administration is an appropriate instrument for implementation of the national land policy. Failure to address land issues in post-conflict period can create significant obstacles to humanitarian interventions and early recovery responses and, if unaddressed, it may contribute to renewed violence - a threat for eruption of secondary conflicts.

\subsection{Conclusions}

This chapter, based on a literature review, increased the understanding of the general characteristics of the conflict and post-conflict contexts in relation to land, other resources and land administration.

Causes of conflicts are varied and many; all conflicts have land dimension. The most serious concerns in present-day conflicts are: the death of people, the destruction of houses and infrastructure and the displacement of population. This research confirmed that natural and other resources can act as a motive for the conflicts and can finances them; it was also confirmed that climate change has an impact on conflicts as well. Compared to the conflicts of the last century, the number of people killed in conflicts nowadays has decreased but more civilians die in conflicts instead of military personnel. This research revealed that the destruction and the displacement had the greatest effect on land and its administration.

It was shown that in some cases land was a major cause or it was one of the many factors that influenced the eruption of an armed conflict. Other related types of conflicts identified here were secondary conflicts and land conflicts. This research confirmed the recognition that land was identified as a critical gap in the international response capacities. It revealed that land issues required specific attention during the state building in post-conflict contexts. From the lessons learned from the researched cases it was shown that it was beneficial when land-related issues and specific land management and administration were included in the peace agreement documents integrated 
in the UN operations. Where this was not the case, development of the land segment occurred later, resulting in the complicating and slowing down of the post-conflict state building. As it was shown from the conflicts in past land was seen as too politically sensitive or technically too complicated to be tackled early in the post-conflict period; this research has demonstrated that it was a mistake not to address land issues promptly.

At the end of a conflict displaced people return to their places of origin in large numbers. This research has shown that together with this land-related issues like burned or destroyed houses and properties illegally occupied by secondary occupants are critical in the post-conflict contexts. The normative framework for addressing housing, land and property rights in context of displaced persons is summarised in COHRE (2007), known as the 'Pinheiro Principles'. In this research, land and property disputes and claims in postconflict period were recognised as threatening issues. When left unaddressed, they were a cause for new violent situations and secondary conflicts. The researched literature confirmed that land administration systems suffered mostly from the loss of land records and loss of land professionals. Having acknowledged the goal of land administration and its potential, land administration was deemed as an appropriate instrument for the implementation of the national land policy, and this should be embedded in a wider development plan of the state emerging from conflict. 


\section{Chapter 3}

Conflict and post-conflict land administration - the case of Kosovo*

\footnotetext{
* This chapter is based on an ISI journal article published as:

Todorovski, D., Zevenbergen, J. and van der Molen, P., (2015). Conflict and postconflict land administration - the case of Kosovo. In: Survey Review, pp. 13, [In press], DOI: $10.1179 / 1752270615 Y .0000000044$
} 


\begin{abstract}
Land and its administration are always negatively affected during conflicts and in post-conflict periods. If land and its administration are neglected or not properly addressed after the end of a conflict, they can be a cause for a renewed armed conflict and an obstacle in the rebuilding of a post-conflict society. This chapter aims at identifying interventions in land administration that occur in conflicts and post-conflict contexts and relate them to the characteristics of post-conflict societies. A case study is conducted in Kosovo, where with the support of the international community developments in the land administration sector were evident. A strong relation is recognized between interventions in land administration and the characteristics of postconflict societies. In this regard, it is revealed that strengthening the institutions in the land sector, which obviously occurred in the case of Kosovo, had a positive impact on the institutional weaknesses of a postconflict society. In addition, interventions in housing and property rights and land administration are identified as elements that contributed to solving the prevailing social and economic problems. Addressing specific land issues in the peace agreement document and the availability of a land dispute resolution mechanism supported settling disputes over land and reduced conflict tensions; these interventions supported the overall security situation. This chapter concludes that interventions in land administration indeed facilitated the rebuilding of post-conflict Kosovo.
\end{abstract}

\title{
3.1 Introduction
}

There is a specific correlation between conflict and land: they meet each other at every point of the cycle of armed conflicts. This is observed in many countries around the world (Guterras, 2009). United Nations (UN) 'Humanitarian response review' identified land as a critical gap in international response capacities (OCHA, 2005). Awareness of the importance of housing, land and property issues in post-conflict contexts has increased over the past 15 years, which is significantly shown in the literature related to the issue, where the correlation between conflict and land is elaborated on and the effects of their mutual impacts before, during and after the conflict are investigated and documented (EU-UN, 2012; FAO, 2005; Pantuliano, 2009; UN-HABITAT, 2007, 2009; Unruh and Williams, 2013b). Recognising the important role that land plays in conflicts and post-conflict contexts, this chapter explores how land is administered in these circumstances.

The aim of this chapter is to identify interventions in land administration in conflict and post-conflict contexts and link them with the characteristics for rebuilding post-conflict societies. Linking these two topics is supported by the assumption that a relationship between the two exists. This relationship will 
be further investigated in order to identify how interventions in land administration contribute to the rebuilding of post-conflict societies.

One of the countries where the intervention in land administration in conflict and post-conflict contexts can be explored is Kosovo. Kosovo is a country where discriminatory laws were applied in relation to real estate transfers before the conflict. The Organisation for Security and Co-operation in Europe (OSCE), found out that more than half of the population was displaced and almost half of the housing units were destroyed or left uninhabitable as a consequence of the conflict (OSCE, 2000). All state archives, including cadastre and property archives, were partially or fully removed from the territory of Kosovo (Ratia, 2000). According to the United Nations High Commissioner for Refugees (UNHCR), after the end of the conflict, a new wave of displacement took place. The properties of those displaced after the conflicts were the target of new destruction as revenge, or were illegally occupied by returnees from the conflict period (UNHCR, 1999a).

To better understand the interventions in land administration in conflict and post-conflict contexts, a qualitative research approach (obtaining data via a case study) was applied to our case - Kosovo. During the fieldwork, primary data were collected in interviews with relevant local (9) and international (6) professionals involved in the land sector in Kosovo, and secondary data were collected from various organisations dealing with land issues (Todorovski, 2013a; 2013b; 2013c). A comprehensive literature review complements this research.

In this chapter, the logical argument is organised as follows. First, in the next section, conflict and post-conflict land administration, and post-conflict societies are addressed based on the available literature. The findings from the collected evidence from Kosovo are elaborated per conflict phase in the following four sections, which show the identification of the various interventions in land administration. Identifying these interventions suggests that they can be recognised as elements addressing the different characteristics for rebuilding a post-conflict society. To build on this, the next section discusses the rebuilding of post-conflict Kosovo in relation to land in post-conflict context. This is done in the structure of the characteristics of war-torn societies as given by Ball (2001). In the final section the chapter concludes that interventions in land administration address these characteristics and this contributed to rebuilding of post-conflict Kosovo. Further investigation to which extent this contribution exists is recommended. 


\subsection{Conflict and post-conflict land administration, and post-conflict societies}

In this section, an overview of the available literature is presented on the topics (1) conflict and post-conflict land administration and (2) post-conflict societies.

\section{Conflict and post-conflict land administration}

Causes of armed conflicts are many, and they may be found in territory, ideology, dynastic legitimacy, religion, language, ethnicity, selfdetermination, resources, markets, dominance, equality and, of course, revenge (Heinz-Jürgen et al., 2006). Among the characteristics of violent conflict, the most serious concerns are the number of people killed, widespread destruction of properties and infrastructure and displacement. While wars today seem to kill fewer people than conflicts in the past, greater numbers of civilians appear to be exposed to and become vulnerable to violence (UNHCR, 2012). The UN reports that at the end of 2013, approximately 51.2 million people worldwide were forcibly displaced as a result of violent conflicts (UNHCR, 2014). Also, it appears that, although most violent conflicts are not 'caused' by conflicts over land per se, almost every major eruption of a violent conflict has had a land dimension (Putzel, 2009).

The post-conflict period starts when the main hostilities have ceased, some kind of peace agreement document is signed and international assistance can be given. This period generally distinguishes three phases: emergency, early recovery and reconstruction. Some scholars observe post-conflict phases based on time (Maier, 2010) and according to Food and Agriculture Organisation (FAO) of the UN, based on activities undertaken (FAO, 2005). Activities in the emergency phase typically focus on the establishment of basic governance and the provision of humanitarian services. Activities in the early recovery phase could be identified as the development of policies, strategies and legal frameworks, the establishment of government and administrative infrastructures, and the development of interim and long-term policies. The reconstruction phase is characterised by the implementation of those policies, strategies and laws from the early recovery phase. The phases should not be understood as absolute, fixed, time-bound or having clear boundaries, but are contextually determined (FAO, 2005; NEPAD, 2005).

Land issues always arise during the conflict, but they become very complex immediately after the conflict as many displaced people return to their places of origin and find their houses and properties destroyed, damaged or illegally occupied by secondary occupants (Leckie, 2000). The moment of return of the displaced persons is considered as critical, because frustration about lack 
of justice and fairness easily lead to the eruption of a new conflict. Other land-related issues that come up in the conflict and post-conflict contexts are landlessness, access to land, non-functional land administration systems, forced transactions, emergency occupation of land, and housing and property rights. Land disputes and claims over land are a very frequent problem in post-conflict settings. Thus land dispute resolution mechanisms are viewed as a conditional tool for a good peace process (Unruh, 2001). Observing the conflicts from the past, a joint European Union (EU) and UN publication (EUUN, 2012), concludes that in the majority of cases, land is seen as politically too sensitive or technically too complicated to be tackled early in the postconflict period. In addition, Wehrmann (2005) claims that the criteria of good governance applied to post-conflict land policy and land management would provide a good basis for a sustainable and low-conflict development.

By identifying the specific role that land plays in conflict and post-conflict contexts, this chapter further explores how land is administered in these circumstances. Land administration is here considered as the process of determining, recording and disseminating information about tenure, value and use of land when implementing land management policies' (UN/ECE, 1996). Land administration is the appropriate instrument for implementing national land policies, with a number of functions such as support for the establishment of a land market, land use planning, land tax administration and management of state land (van der Molen, 2002). Post-conflict situations lead to a dysfunctional land administration system characterised by limited prioritisation of land policy, discriminatory land law, a poor institutional and regulatory framework that allows the grabbing of public and private land by powerful individuals and groups, poor management information systems for updating records as well as weak state capacity that was incapable of helping internally displaced people and refugees (Augustinus and Barry, 2006). The most obvious blow for land administration in post-conflict contexts follows from the loss of staff and records. Staff can be killed, (forced to) leave the area or not be able or willing to return to their jobs within land administration systems (Zevenbergen and Burns, 2010). Incomplete, out of date or contested land records can pose a threat to tenure security and the overall peace situation. United Nations Human Settlements Programme (UNHABITAT) argues that issues about land records in a post-conflict situations that require appropriate attention are inadequate land records, fragmented responsibility for land records, lost, stolen, fraudulent and altered land records and women and children's property and inheritance rights (UNHABITAT, 2009).

The literature about long-term capacity building in developing, transition and post-conflict countries in the area of land administration reveals that this is often a missing link. It appears that the usual capacity building focus is on 
short and mid-term, and is often synonymous to human resources development, training and education of staff only (Enemark, 2003). Adequate developments of the land administration system should cover the appropriate building of the capacities not only at an individual level but also on an organisational and societal level. Even when the key focus is on education and training only to meet the short and medium term needs, capacity building measures should also address the wider context of institutional infrastructures to safeguard the implementation of land polices in a sustainable way (Enemark and van der Molen, 2008).

We found that housing and property rights and land administration are always negatively affected by conflicts and if not addressed properly in a post-conflict context they can be a cause of secondary conflicts and even erupt into another armed conflict (Todorovski et al., 2012b). Looking back in history, in the majority of conflict cases peace agreement documents (PAD) contained only limited references to land issues, mainly in relation to displaced people and their basic human right to return to their properties with dignity (examples are Cambodia (PAD, 1991) and Mozambique (PAD, 1992)). However, literature shows that there is a need to ensure that land issues are put on the agenda of the international community and that they are tackled in peace agreement documents or national land policies of the states emerging from a conflict (EU-UN, 2012).

\section{Post-conflict societies}

After hostilities have ceased and a peace agreement has been signed, in general, the first challenge that post-conflict societies face is the peacekeeping process, which is understood as a situation with absence of armed conflict and a modicum of political process. Peace building is described as a compound of actions undertaken by international or national actors to institutionalise peace (Call and Cousens, 2008). Peace building requires some form of doing justice and if justice is required, rule of law becomes one of necessary perspectives for looking at the given post-conflict context (Buyse, 2008). It is recognised that the rule of law is critical to states emerging from conflict on their way towards stability and long-lasting peace. It is important that the rule of law is not only provided for in the law but is also practiced by the officials of the state, allows participation of the citizens and is enforced by the courts (Rugege, 2013b). Having cognisance of what institutions are (e.g. 'rules of the game') the development of institutions would entail the rule of law.

But apart from the peace-keeping challenge, what makes up the rebuilding of post-conflict societies? The Organisation for Economic Co-operation and Development (OECD) defines state building as 'purposeful action to build 
capacity, institutions and legitimacy of the state in relation to an effective political process to negotiate the mutual demands between the state and societal groups' (OECD, 2008), or Fukuyama as 'the creation of new government institutions and the strengthening of existing ones' (Fukuyama, 2004). In particular, when it regards state building in post-conflict contexts, we refer to Ball (2001), who elucidates the rebuilding of war-torn societies and postulates three main characteristics. First, she describes 'institutional weaknesses', like non-participatory and malfunctioning political and judicial systems, strong competition for power instead of attention to governing, a limited legitimacy of political leaders and no consensus on which way society should go. Second, she observes 'economic and social problems', like a destroyed or decaying social and economic infrastructure, an increase of the illegal economy, people reverting to subsistence activities, hatred among population groups and conflicts over land and property. Finally, she distinguishes a third element, namely that these societies have to cope with serious 'security problems', such as huge quantities of small arms freely circulating among the population, political influence of the armed forces, demobilization and disarmament. Because the characteristics of war-torn societies developed by Ball (2001) are widely accepted, we will apply those when we will discuss post-conflict societies in relation to land within postconflict context, in particular for Kosovo.

A related condition might be that in post-conflict contexts close and unified co-operation between all actors is essential. International actors with available resources and skills should facilitate local processes and create a space for local actors who are the main work force. Together they should define and consolidate their policies in order to build responsive, resilient and robust institutions (Chesterman et al., 2005).

After this short overview on the available literature on conflict and postconflict land administration and post-conflict societies, the following sections will explore these theoretical aspects in a real-life situation about the interventions in the land administration (a) before and during and (b) after the conflict in the case of Kosovo.

\subsection{Before and during the conflict in Kosovo: how was land administered?}

In this section we will address the land administration situation before, during and at the end of the conflict in Kosovo. We base ourselves on our case study and on existing literature. 


\section{Before the conflict: how was land administered?}

Land administration in Kosovo, before the tensions intensified in 1989, was under the jurisdiction of the Directorate for Cadastre and Geodesy of the Socialistic Autonomous Province of Kosovo. The headquarters were based in Pristina. Municipal Cadastral Offices (MCO) were established in 26 municipalities, while 3 municipalities had no local cadastre office but were serviced by one of the others (Vikman, 1999). The total number of employees in the Directorate and the MCOs varied from 300-350 at different time periods (Todorovski, 2013a). The legal framework under which land administration was practiced was based on the 'Law on land survey and cadastre' of the Socialistic Republic of Serbia (Republic of Serbia, 1976).

Property rights were, of course, approached from a socialistic perspective. Residential property in Kosovo had two primary categories: private single family homes and socially owned apartments. The apartments were built and administered by either socially or publicly owned enterprises, primarily for their employees. Employees were allocated with permanent rights of use over these apartments known as occupancy rights as derived from the Law on Housing Relations from 1986 (Republic of Serbia, 1986). An occupancy right was less than an ownership right but considerably more than a leasehold right (Cordial and Rosandhaug, 2008). Privatisation was introduced with the Law on housing from 1992, which allowed purchasing of the apartments and converting the occupancy rights into full ownership rights (Republic of Serbia, 1992). An independent Agency for the Registration of Apartments was established, mandated to record these apartment rights and to monitor the process of privatisation (Todorovski, 2013b). This Agency was also based in Pristina.

In the beginning of the 1990s the Government of the Republic of Serbia enacted a series of laws and administrative measures known as 'special measures': a programme for achieving peace, freedom, equality, democracy and prosperity in Kosovo. Although these measures were not specifically discriminatory in text, application of the measures resulted in discrimination. One of the side effects was the removal of the Directorate for Cadastre and Geodesy of the Socialistic Autonomous Province Kosovo to the Republic Geodetic Authority in Belgrade in 1991 (Todorovski, 2013a). Performance of the land administration in Kosovo was further hindered by the 'special measures' referring to two laws, later found by United Nations Interim Administration Mission in Kosovo (UNMIK) as also being of discriminatory nature (UNMIK, 1999b):

- The Law on Changes and Supplements on the Limitation of Real Estate Transactions (Republic of Serbia, 1991a); and 
- The Law on the Conditions, Ways and Procedures of Granting Farming Land to Citizens Who Wish to Work and Live in the Territory of Kosovo and Metohija (Republic of Serbia, 1991b).

Discriminatory effects came in particular from the first law, which almost fully limited transactions of real estate property and required that every contract for purchase, lease and sale of real estate in Kosovo needed to be approved by the Directorate of Property Rights Affairs of the Ministry of Finance in Belgrade. The Ministry could refuse to approve the transaction if it considered that it would have had an effect on 'the national structure of population' or on the 'emigration of members of a particular ...nationality' (OSCE, 2000). This law had the objective and effect of restricting the transactions of property from Serbs to Kosovo Albanians as a means of ensuring that the Serb population in Kosovo did not decline. Some $98 \%$ of the files were reported as 'being rejected' by the Ministry of Finance. As a consequence, the citizens had no other option and they continued making informal property transactions which were not registered in the cadastre (Cordial and Rosandhaug, 2008), which deteriorated the quality of the files. With this intervention, the functions of land administration in Kosovo were negatively influenced and after the conflict land records were already about ten years out-of-date, not fully reflecting the situation on the ground (Ratia, 2000).

From a technical viewpoint, in the period before the conflict, all the MCOs were equipped with personal computers and software for cadastral updates and maintenance in which all cadastral units and all cadastral parcels were inserted. This software was used for issuing a copy of the possession list and also for registering all new transactions in the electronic form. A back-up of the datasets was done periodically which proved to be very useful for the period after the conflict (Todorovski, 2013a).

Other federal laws were passed between 1992-1996 (e.g. the Law on Public Survey and Registration of Real Estate Rights; Republic of Serbia, Official Gazette No. 83/92, 53/93, 48/94, 12/96, 15/96), which introduced a radical change of transforming the 'land' cadastre into a 'real estate' cadastre. However, there was neither funding nor were there qualified professionals to implement the proposed changes in Kosovo (Zherka et al., 1999). Although the headquarters were moved to Belgrade, municipal cadastral offices still existed in Kosovo. Just before the conflict there were 250 employees working in those offices: about 150 Serbs and 100 Kosovo Albanians (Ratia, 2000).

As a summary, prior to the conflict the administration of land was becoming part of discriminatory practices. The practice to circumvent such laws resulted in informal transactions not recorded in cadastral records. Records 
were partly located at local municipal offices and at the headquarters, which were moved to Belgrade.

\section{During the conflict: what happened in Kosovo and what happened to the housing and property rights?}

The conflict in Kosovo escalated after an event that took place on 28 February 1998. After four police officers were shot in Likosane, Serbian police conducted a series of actions in the Drenica region of Kosovo. Houses were burned, villages emptied, and dozens of Kosovo Albanians were killed. In many reports this date is seen as the start of the armed conflict (HRW, 2001). Our findings reveal that this clash was a development caused by a self-determination movement, whose goals intensified after adaptation and implementation of the earlier mentioned 'special measures'. A study of Spiegel and Salama (2000) estimates 12,000 people killed directly related to the war in the following period from February 1998 to June 1999 - based on a survey performed among Kosovo Albanians. However, according to the Government of the Republic of Serbia the numbers of non-Albanian people killed and missing in the armed conflict on the territory of Kosovo in the period January 1998 - November 2001 is set at 3,276 (Republic of Serbia, 2001). Inspective of the number people killed, it already depicts the seriousness of the conflict at this stage.

In the period prior to the North Atlantic Treaty Organisation (NATO) intervention in March 1999, more than 260,000 people were estimated to be internally displaced in Kosovo and an additional 100,000 in the region (Morris, 1999). By the end of the conflict, almost half of the total population of Kosovo (then approx. 800,000) sought refuge in neighbouring Albania, Macedonia and Montenegro. Estimates vary, but it has been estimated (UN, 1999a) that up to 500,000 persons may have been categorized as IDPs.

The long confrontations between the Kosovo Albanians and Serbian authorities attracted prolonged attention of the international community. After intensification of the violent conflict, the UN Security Council adopted a series of Resolutions on Kosovo in 1998 and 1999. Also the European Union and NATO were strongly involved, both politically and militarily. An attempt to end the conflict was made with the start of negotiations in France in February 1999 but the resulting document was not supported by Yugoslav Authorities. By consequence, there was no official Peace Agreement signed by both sides in the conflict. Instead of a mutual agreement, Kosovo Albanians and representatives of the international community signed the Rambouillet Accord 'Interim Agreement for Peace and Self-Government in Kosovo' (Rambouillet, 1999) in Paris, France, on 18 March 1999. Subsequently, and on request of the UN Security Council, on 24 March 1999 
NATO began its aerial military intervention against the Republic of Serbia. After an intensive bombing campaign, the conflict finally ended on 9 June 1999 with the signing of the Military Technical Agreement (NATO, 1999) between the NATO and the Government of Yugoslavia.

What happened meanwhile to the housing and property rights? Surveys performed by the international community estimated that some 103,000 housing units were either destroyed or rendered uninhabitable, representing almost half of available housing units in Kosovo and that as many as 75,000 properties were abandoned (Valstad, 2004). UN (1999a) identifies that 'serious violations of property rights in Kosovo have occurred before, during and immediately after the military conflict'. Land administration during the armed conflict functioned with lower intensity. There were only a few official land transactions based on court decisions and registered in the cadastre. The circumstance that highly affected its work was the announcement that NATO was preparing to bomb the whole territory of the Republic of Serbia (including targets in Kosovo) from the air. Because of this, a majority of civilians were displaced to safer places leaving their properties behind. All municipal cadastre offices were closed during the NATO intervention. From 20 March 1999 the office in Pristina was closed for about four months (Todorovski, 2013a). Implementation of the 'special measures' and the conflict itself resulted in a number of absent and dismissed employees. The number varies with the sources. One of our interviewees said that no one from MCOs was forced to leave until one month before the NATO intervention, because they were public administration officers who were bringing in tax funds to the state budget (Todorovski, 2013b), another source said 'a few in higher positions at the MCOs were fired' (Todorovski, 2013c). A third source states 'during the period 1989-1999, 205 Albanians, with secondary and university education, were fired from respective cadastral departments' (KCA, 2011). Whichever source is correct, capacity was deteriorating.

Another complicating factor was that Serbian authorities when retreating, removed all archives from the public authorities and this was also the case with the archives from the municipal cadastre offices. In a majority of international reports and in the literature, it is stated that the Yugoslav Army and in some cases the Russian Military executed this activity. A frequently repeated story about this event (stated here by one interviewee) is that in the period of 20-24 March 1999 the Yugoslav Army arrived with trucks and removed all the cadastral original plans with updates, cadastral archive documentation, geodetic equipment and personal computers from the Pristina municipal cadastre office' (Todorovski, 2013b). However, from the interview with a retired head of the Kurshumlija cadastre office in a newspaper, it could be derived that removal of the cadastral archives was 
done by order of the President of the Republic of Serbia to the Director of the Republic Geodetic Authority. The Director delivered this task to the heads of the cadastral offices from Serbian territory, nearest to Kosovo. The head of the Kurshumlija cadastre office and the head of Vranje cadastre office with assistance of local transporters removed the cadastral archives from the Pristina cadastre office and ten other cadastre offices from the territory of Kosovo when the Yugoslav Army and Serbian police retreated at the end of the conflict (Zecevic, 2012). The fact that cadastral records were taken to Belgrade, later appeared to be a huge obstacle in the implementation of the peace agreements.

The large numbers of displaced people, the destroyed houses, illegal occupation of properties and the incomplete and out-of-date property registration system created numerous housing and property rights and land administration problems for the coming post-conflict period (Cordial and Rosandhaug, 2008).

\section{At the end of the conflict: how were the housing and property rights dealt with?}

Looking back to the conflict, Wallensteen and Moller (2003) consider the Kosovo conflict as an intra-state type of conflict which resulted in a state's formation. The UN Security Council, by its resolution 1244 (UN, 1999a) on 10 June 1999, authorised the Secretary-General, with the assistance of the relevant international organisations, to establish an international civil presence in Kosovo, in order to provide an interim administration. This effectively transferred Kosovo into a UN protectorate. The preliminary concept for the UNMIK was presented to the Security Council on 12 June 1999 (UN, 1999b) and the detailed report of the UN Secretary-General on the UNMIK mission in Kosovo was presented to the UN Security Council on 12 July 1999. This detailed report can be considered as a basic document for building the new-born state of Kosovo (UN, 1999c).

What does it say about housing and property rights, and related administration? The detailed report of the Secretary-General on UNMIK (UN, 1999c) included specific housing and property rights and land administration issues. From the section relating to the situation on the ground about security issues immediately after the conflict it can be derived that 'an increased number of incidents committed by Kosovo Albanians against Serbs were noticed, in particular, a high profile of killings and abductions, as well as looting, arsons and forced expropriation of apartments'. Prominent attention was given to issues related to refugees and IDPs, and their secure return to their homes and properties in the sections related to the 'humanitarian situation' and the 'administration and public infrastructures'. In the section 
'main components of the mission' housing and property rights issues were tackled, more precisely: 'how to establish a registry of property claims' and 'redress legal measures on property, and rebuilding property and cadastral records' (UN, 1999c). The international community appeared to be aware that the conflict left the administration of land with huge gaps (Valstad, 2001).

From this sub-section it reveals that at the end of the conflict the UNMIK administration was aware of the land question. In the following section we will see how public interventions developed, during each of the three generally accepted and for this chapter adopted phases of post-conflict: 'emergency', 'early-recovery' and 'reconstruction' phases.

\subsection{Emergency post-conflict Kosovo: housing and property rights and land administration}

Associating the post-conflict phases to the case of Kosovo based on activities, the 'emergency' phase could be observed from the moment that the Military Technical Agreement was signed in 1999. This phase lasted for two years until mid-2001, when the 'early recovery' phase started.

The period of the first 6 to 12 months after the conflict was also known as a 'lawless' period, which was the result of having many laws in force which were labelled as discriminatory by UNMIK and which were subsequently abolished. Preparation and adoption of new laws required a long time and meanwhile old laws from the period before 1989 were allowed to be applied at least if they were not found to be discriminatory (Todorovski, 2013c). Land issues come to the forefront specifically in the emergency post-conflict phase, when a mass of people return to their place of origin in a short period of time (HPG, 2008). This was also the case in Kosovo. The largely spontaneous repatriation of refugees began, and it is reported that by the end of July 1999, more than 700,000 refugees had already returned to Kosovo (UNHCR, $1999 \mathrm{~b})$. At the same time violence against minority groups was rife and caused a mass exodus of mainly Serbs, but also Roma and other nonAlbanians, who fled, fearing reprisals by the Kosovo Albanian population (Cordial and Rosandhaug, 2008). There are several estimates of the number of all non-Albanians who fled from Kosovo; UNHCR (1999a) estimates that 245,353 people were displaced after the end of the conflict.

One of the characteristics of conflict and post-conflict contexts is that displacement and return foster the urbanisation process (Todorovski et al., 2013). Pristina was the most populated city in Kosovo however its population doubled after the conflict. In 1991 the city was home to about 200,000 
inhabitants, by February 2000 it was estimated that the population had risen to approximately 550,000, including 200,000 IDPs (OSCE, 2006).

Activities related to housing and property rights in the emergency phase had their impact on the security situation. There were numerous reports of illegal occupation of land and property, as well as indications that criminal groups were profiting from the instability by taking control of houses and land (Vikman, 1999). As many Kosovo Albanian returnees found that their homes had been damaged or destroyed, they moved into the properties that had been abandoned by Serbs and other minorities, causing unauthorised 'secondary occupation' of properties (Leckie, 2000). This was particularly the case in the cities as many Kosovo Albanians moved from the countryside into the cities in search of accommodation and work. Abandoned properties were often reallocated by local authorities and this ostensibly served the purpose of providing humanitarian shelter but ultimately served to reward political patronage as allocations were made in favour of so-called political or military elites as rewards for loyalty (Cordial and Rosandhaug, 2008).

Another activity in relation to housing and property rights was that some properties which were burned and destroyed due to the conflict in the urban areas were declared ruins by the municipal commission. Possession of these properties was declared to be converted to the municipalities as public land for reconstruction and development. Even after the conflict the burning and destruction of properties, especially bigger abandoned estates previously owned by Serbs, continued and these properties were transferred from being privately owned into publicly owned properties which were later distributed in the same way as the abandoned properties (Todorovski, 2013c).

Allocation of public land is a usual practice in post-conflict contexts. For example, to provide locations for first aid centres, camps for returnees, location for facilities for the international community and international security troops etc. This practice also took place in Kosovo, but this was done in a non-transparent way. Beneficiaries from the allocation of public land were the followers of the new political elite and military commanders. This is supported by the fact that there were court cases against people under suspicion of fraud, which resulted in some persons in 'high' positions in the land sector being jailed. An example of this was a head of the Pristina municipal cadastre office, who spent six months in jail (Todorovski, 2013c).

The emergency phase shows a volatile picture of dealing with housing and property rights. How was that with the land administration activity? 


\section{Land administration in the emergency phase}

Reports and documents from the UN and the EU agencies note that immediately after the conflict work teams were created for the assessment of the situation on the ground about the status of land administration in Kosovo (TOR, 2000). The mandate for action for these activities was given to the United Nations Environment Protection (UNEP) and the UN-HABITAT agencies. A Balkan Task Force was created on 9 April 1999 by the Executive Director of UNEP and UN-HABITAT. The Task Force mobilised three teams of international experts in order to carry out environmental and human settlement assessments in the region, focusing on the areas of municipal administration, regularisation of housing and property rights, and development of a cadastral information system in Kosovo. For this assessment the Task Force approached the United Nations Economic Commission for Europe (UN/ECE) because of their capability, expertise and know-how on land administration in its Working Party on Land Administration. As such, the UN/ECE secretariat in July 1999 appointed a senior UN/ECE representative to work as a focal point person in the Balkan region. Based on fieldwork for fact findings a comprehensive strategy on land administration in the Balkans and especially for Kosovo was developed later in June 2000 (Ratia, 2000).

The focal person found the prevailing land administration system in a poor state which could be attributed to both the discriminatory laws from the period before the conflict, and destruction, loss and removal of property certificates and supportive documentations (TOR, 2000). The assessment of the situation highlighted the following major areas of concern:

- property certificates and registries had been partially removed;

- property boundary markers, survey control points and associated documentation had been destroyed or defaced;

- geodetic surveying equipment and computers had been removed;

- discriminatory legislation applied over more than a decade and a lack of effective control over property registration and taxation had deterred people from recording property transfers; and

- restrictions in the recruitment of personnel for public sector positions and the displacement of people after the conflict had left many municipal cadastral offices without qualified staff (Valstad et al., 2002). 
The mission led the Swedish Government Agency (Sida) to commission a consultant (Blom International) to carry out a more in-depth study of the situation and to develop a strategy that would support the re-establishment of the system and improve operation of the MCOs (Valstad et al., 2002). Initial proposals for rebuilding the cadastral system defined the following areas of action: inventory and secure existing cadastral information, rebuilding an integral geo-information database, restoring the geodetic network, designing the framework for a modern cadastre and land registration system, in order to meet the immediate demands of the municipal cadastral offices and the establishment of a central co-ordinating facility to guide this task (TOR, 2000). Based on the lessons learned, UNHABITAT developed later the 'Post-Conflict Land Administration and Peacebuilding Handbook' (UN-HABITAT, 2007).

The terms of reference for the implementation of the Kosovo Cadastre Support Programme were the result of the above process, where, for reestablishing efficient mechanisms of governance in Kosovo, the reintroduction of a land and property management system was envisaged. A functional land administration system was considered as a pre-requisite for implementing reconstruction activities such as: upholding the rule of law, promoting economic development and resolving long-standing conflicts and uncertainties (TOR, 2000). Relating land administration to 'governance' and 'rule of law' suggests that developing land administration was considered a contribution to rebuilding post-conflict society (we will elaborate this link hereafter).

\section{Land administration organisation and the legal framework in the emergency phase}

The land administration organisation after the conflict consisted of 26 municipal cadastral offices (for the twenty-nine cadastral municipalities) and the Pristina Institute for Geodesy and Photogrammetry. At the beginning of the post-conflict period this institute was acting in a similar manner as the former Directorate for Cadastre and Geodesy, but its activities were not according to the real needs of the local situation (Todorovski, 2013a). By the end of 2000, at local level, 30 Municipal Assemblies were elected and every municipality had the right to set up their own cadastral office (Anderson and Onkalo, 2004). No formal real estate transactions were being registered in either the cadastre or court registration systems from February 1999 until October 1999. The reason for this was due to the fact that both the court transaction deeds registration system and the supporting cadastral system were not operational (Ratia, 2000). 
The Kosovo Cadastral Agency (KCA) was established in November 2000 as a result of a UNMIK Administrative Direction no. 2000/14 of 7 June 2000 (UNMIK, 2000a). Regarding the legal framework, federal laws passed in 1992-1996 were revoked by the UNMIK in December 1999. Therefore, the 'old' Law on Land survey and cadastre from 1976 (Republic of Serbia, 1976) was in force until the changes in the law were enforced later.

\section{Status of the land records and land professionals in the emergency phase}

The status of land records is reported differently. As we saw earlier, and also noted in the TOR (2000), cadastral documentation was missing completely from six municipal cadastre offices. This included cadastral original plans with updates, paper copies of the cadastral original plans with updates and supportive cadastral documentations (geodetic elaborations, files with data and sketches from field measurements, and files with property documentation). From twelve cadastre offices, covering an area of fifteen municipalities, the cadastral documentation was missing, but mostly for the period of 1989 - 1999. In only eight offices a complete set of cadastral documentation was still present (TOR, 2000). Other sources argue however that overall most of the cadastral original plans with updates had been removed (Valstad et al., 2002). Yet another presentation of the status of removed land records is that only six cadastral offices had a complete cadastral documentation (including cadastral original plans with updates and cadastral documentation) and the rest of the twenty-three offices had only 15 $\%$ of the available cadastral plans and documentation (Meha, 2004; Todorovski, 2013a). In most cases, the municipal cadastre offices had copies on paper from the cadastral plans - but not containing all updates since the late eighties (Blom, 2000). All the archive original cadastral plans made during the years 1950-1984 for the whole of Kosovo were found to be in excellent condition in the former building of the Federal Government in Pristina. However, these cadastral plans did not include updates registered in the cadastre after the recording-production phase (Todorovski, 2013a). In any case, we can assume that a major and essential part of the usual cadastral information was missing.

Valstad (2001) found that, because the data were processed using 'punch card' equipment, it was possible to re-build a digital cadastre based on the back-up of the cadastral records. The system was based on a simple readonly database in MS-Access (Interim Database version 1.0), which was easy to reconstruct from textual data obtained from the Electronic Data Processing Facility of Kosovo, where back-ups for all cadastral records for the whole territory of Kosovo until 1989 were available. Another database, (Interim Database version 2.0) was a read-write database developed in Visual Basic 
and MS-Access. In the second version the cadastre offices were able to improve the quality of the data by introducing new information. Old information from the Interim Database version 1.0 has been archived as a supportive database, and all new updates were based on information found in the cadastre offices up to 1997 (Valstad, 2001).

As the security situation on the ground was stabilising, displaced persons returned and established basic living conditions. Also employees who previously were working in the public sector, started to return to their previous jobs. During the first days of the entry of the United Nations Security Forces for Kosovo, staff members that previously worked in the cadastral offices started reorganising themselves in their own ways (Meha et al., 2004). Around $90 \%$ of the Kosovo Albanians that left their work places during the tensions and conflict period came back to their former work positions after June 1999 (Todorovski, 2013a), whereas large part of the Serbs that left their workplace did not return (Ratia, 2000).

Although there were enough professionals available to quickly start a reconstruction and modernisation of the cadastre with international multidonor support within the Kosovo Cadastral Support Programme, only a few among them had up-to-date relevant professional qualifications in 1999. Most of them were lacking the professional experience of the last ten years, and in that period there had been many technical developments in the field of surveying and cadastre. Onkalo et al. (2002) reported that very few young professionals had graduated in the last few years, and that the new graduates lacked surveying and cadastral work experience. Discrimination in the past had led to a considerable knowledge and skills gap among the professionals. Many employees were excluded from their posts in the municipal cadastre offices in the period of ten years and most were not exposed to new technologies or technical and managerial concepts (Anderson and Onkalo, 2004).

From this sub-section it reveals that different figures and different presentations of the status of the land records and of the quality and quantity of land professionals complicated post-conflict land administration in Kosovo.

\section{Register of property claims in the emergency phase}

The Housing and Property Directorate (HPD) was the central mechanism created by the UNMIK to resolve residential property disputes (OSCE, 2000). The HPD and the Housing and Property Claims Commission (HPCC) were established by UNMIK Regulation no. 1999/23 from 15 November 1999 (UNMIK, 1999a), and the Rules and Procedure and Evidence of the HPD and the HPCC were under UNMIK Regulation 2000/60 from 31 October 2000 
(UNMIK, 2000b). The HPD and its Claims Commission presented refugees and IDPs with the opportunity to file claims for restitution of residential property and to have any disputed claims resolved before an independent quasi-judicial forum in an impartial and transparent manner (Tibaijuka, 2008).

One year after establishing the HDP and HPCC were basically serving as a register of the claims and disputes. Further regulations about operating procedures were needed including the principles of law and evidence that would be applied as a prerequisite for its functionality. It is for this reason that the local population continued to lodge property claims with the courts one example is the Gnjilane Municipal court, where, as of 9 July 2000, 56 out of 110 cases were property cases (OSCE, 2000).

Arriving at the end of the emergency phase, we conclude that in line with the UNMIK document, which included specific housing and property rights, and land administration issues, various institutions were created, both concerning law and organisations. The international community was prepared to contribute to better housing and property right regimes and to better land administration. Although staffing remained problematic, the early recovery phase could start with a certain fundament for the further development of the land sector. We will see how that worked out in the following sections.

\subsection{Land administration in Kosovo in the early recovery post-conflict phase}

Based on the activities that characterise an early recovery phase, this phase in Kosovo was from mid-2001 to the end of 2003.

In this early recovery phase two important developments took place: first, the implementation of the Kosovo Cadastral Support Programme, an umbrella programme that developed the function of cadastre and the capacities of associated stakeholders in Kosovo, and, second, the regulation to decide on property claims.

The developments in the area of land administration in the post-conflict early recovery period were focused on the implementation of the UN-HABITAT's Kosovo Cadastral Support Programme. Generally, the implementation programme has been recognised as good practice where all actors involved were very well co-ordinated, including the donor organisations and the UN agencies. From the situational review of the land administration sector in Kosovo (Smith, 2002) and the final report of the Programme (Anderson and Onkalo, 2004), interesting outcomes and lessons can be learned. In any case, the final report underlines the 'decisive development of the land 
administration in Kosovo which took place from 2000-2003' and identifies strengths and weaknesses which may be beneficial for other cases of interventions in land administration in post-conflict contexts. In the following part we will see what the Programme delivered and how did it materialized, in particular institutional (law and organisation) and how justice was served (claims and restitution).

\section{Kosovo Cadastre Support Programme}

The programme started in November 2000 and it was completed in October 2003. The overall objective of the project was to 'create a well-functioning land sector which will contribute to economic growth, democratic and sustainable development supported by a real property market, rights protection and an improved cadastral and land registration system'. This overall objective distinguished two 'sub'-levels. On the municipal level, the objective was: 'municipal cadastre offices should be able to render proper land and property services to the beneficiaries'. On the central level, the objective was: 'create improved development, co-ordination and implementation of cadastral activities in Kosovo' (Blom, 2000).

To establish the Kosovo Cadastral Agency as an institution at central level and to strengthen the municipal offices at local level were thus two important and major parts of the Programme. These parts have been achieved and according to the report, 'have reached beyond the initial objectives' for the central Agency, while for the municipal cadastral offices 'the development for different reasons has not been so encouraging' (Anderson and Onkalo, 2004).

Regarding the Agency, at the end of the Programme, it was established as a well-respected organisation with a good reputation in the region, employing well-trained personnel. At the end of 2002 there were fourteen international and thirty-two local experts in the Agency and together with the administration and support staff there were eighty employees in total. However, in July 2004, the total number of KCA employees fell to fifty-four, all being local (Valstad, 2004). Key successes of the Programme were the renovation of the technical infrastructure related to the cadastre and the land administration, and the upgrade of the technology and development of new tools and processes for the Agency and the municipal cadastral offices. These successes occurred in three different areas: the fundamental geodetic framework, new ways of registering immovable property rights and possession to land and a new ways of mapping immovable property. Another success of the Programme was the recognition that the functions of the cadastre and land administration are established to provide products and services according to the needs of the stakeholders. Within the Programme the collaboration of all stakeholders in building common ideas and visions for 
Cadastral and Land Information Systems was evident (see Annex 6 in (Anderson and Onkalo, 2004)). The Agency took a leading role in shaping governmental policies such as: the 'Development of Strategy', the reform of the Property Law (2003) and the Land Administration Policy (2003). In this period two very important laws for the performance of the Agency and the municipal offices were adopted: Law on the Establishment of Immovable Property Rights Register (UNMIK, 2002) and the Law on Cadastre (UNMIK, 2003).

The cadastral offices operated as independent entities organised under the Ministry of Public Services. All cadastral surveys and registration of cadastral information were carried out by the municipal cadastral offices and the Agency provided a lot of resources to bring them up-to-date on technology and skills. Along with the training of staff and the delivery of computers, the offices could start updating the cadastre on their own at the end of 2001 (Valstad et al., 2002). Within the Programme training courses were developed for all employees (on both central and local level) about subjects such as basic Windows, the use of Total Station, GPS and GIS software (Onkalo et al., 2002). Although in 2004, the municipal cadastral offices employed about 300 persons, the result of all the training was unsatisfactory. Only four offices achieved a satisfactory level in handling the new technology (Valstad, 2004).

By recognising that the central Agency and the municipal cadastral offices did not have a hierarchical relationship, there was an initiative to organise both into a single organisation. This might ensure financial sustainability and one responsible body for surveying, mapping and cadastre (Valstad, 2004). But until today this single organisation was not realized: the municipal offices fall under the Ministry of Administration and Local government, and the central Agency is an agency under the Ministry of Environment and Spatial Planning, with mandate to guide and support MCOs (Todorovski, 2013a). Shala et al. (2015) presenting the reforms on the law on cadastre in the Republic of Kosovo, acknowledge that the initiative to organise both under one organisation is coming soon.

From the very beginning of the Programme there has been a tremendous demand for information about possession rights and in particular for geoinformation, from a range of customers. Most of the customers preferred digital data in order to be able to use those in their own digital systems. The Agency and the offices could quickly deliver aerial photos and orthophotos in digital form and hard copies. For example, municipalities used these data in urban planning and in Property Tax Pilots to identify and register buildings and apartments. The Kosovo Trust Agency used the geo-information together 
with cadastral data to prepare for the privatisation of socially owned enterprises (Anderson and Onkalo, 2004).

\section{Register of property claims and property restitution in the early recovery phase}

For the displaced population who found their properties totally destroyed and for whom it was impossible to go back to their homes, an alternative shelter was provided. Where possessions were intact, many people faced difficulties, even violations in relation to the repossession of their property. Commonly secondary occupation made re-establishment of property rights impossible. For those people an opportunity was given to submit a land claim for property restitution via the mandated agencies: the Housing and Property Directorate in the beginning and later the Kosovo Property Agency (KPA).

Rules and Procedure for Evidence of the Housing and Property Directorate and the Housing and Property Claims Commission were established under UNMIK Regulation 2000/60 (UNMIK, 2000b). The Directorate developed its internal operating procedures later and their practical implementation was prolonged. These operating procedures focused on making the process accessible to all potential claimants. Offices were initially opened in Kosovo in four of its regions and mobile units served minority enclaves and rural areas. However, as it subsequently became apparent that the majority of potential claimants were dispersed outside Kosovo, representative offices were established in these regions in late 2001. Following lengthy negotiations with the authorities in Serbia, offices were opened in Belgrade (Serbia), Podgorica (Montenegro) and a small liaison office was also opened in Skopje (Macedonia) (HPCC, 2007). In total 29,160 claims were lodged and the Directorate started the adjudication of claims in January 2001. Meanwhile all claims have been decided upon and as of April 2008 decisions have been implemented in $99.9 \%$ of all cases (Cordial and Rosandhaug, 2008). The Directorate's and Commission's mandate were finished on 6 June 2007 and there was a transfer of responsibilities to the Kosovo Property Agency.

Reports reveal that the Kosovo Cadastre Support Programme worked out well and a cadastre function started to develop. Potential threats to the peace after every conflict in general are 'conflicts over properties' which were tackled adequately in Kosovo, at least a first substantial trench. These circumstances appear to be a good starting point for the third and last postconflict phase, the reconstruction. 


\subsection{Land administration in Kosovo in the reconstruction phase}

As regards the activities that characterise the reconstruction phase in the case of Kosovo, this phase started at the end of 2003. The reconstruction still continues today.

After the Cadastre Support Programme ended in November 2003, there was an extension of the Programme for the next three years: the 'Support Program for re-establishment of the Cadastre in Kosovo'. The period from 2004 onwards has been a period where many related projects and different donors supported the development of land administration in Kosovo. The main activities that the projects addressed in this phase were:

- Reconstruction of Cadastral Information;

- Building Cadastre Construction;

- Kosovo Positioning System - KOPOS;

- New law for Cadastre 2011;

- Address register 2012;

- Digital topographic maps 1:2500, JICA 2013;

- GeoPortal;

- KCLIS, the overall project for harmonisation of maps and cadastral data, the first module being the textual (legal) data and second graphical (mapping) data (Todorovski, 2013a).

Donors and funding organisations involved in these project activities were the Norway project implementation via Statenskartverket (2004-2013), World Bank, which financially supported the RE CAP project (2006-2011), and continued for next 5 years; in 2008 GTZ (now GIZ) started a project on Land Management and Cadastre which finished at the end of 2013, with the possibility for continuation of the project (Todorovski, 2013a).

The continuation of these projects and all related activities shows that the Kosovo Cadastral Support Programme has been a programme with the perspective of long-term continuous development of the functions of land administration in Kosovo.

Also the procedures to solve property claims continued. As has already been stated, the Kosovo Property Agency was established as an - independent agency by promulgation of UNMIK 2006/10 'On the Resolution of Claims Relating to Private Immovable Property including Agricultural and Commercial property' (UNMIK, 2006). As of 16 December 2014, this Agency received 42,479 claims in total ( $99 \%$ of which were related to ownership and $1 \%$ related to user rights), where the number of decided claims was 42.116 
and 363 of which were withdrawn by claimants. Implementation of the decisions is expected to be done until mid-2015 (www.kpaonline.org). Implementation of the decisions from the claims was further processed within four procedures: claim closure (with possibility to reopen the case) implementation of compensation scheme, repossession of property and administration of the property by the Kosovo Property Agency (KPA, 2012).

From all this about the post-conflict property restitution we can derive that in cases where land records and supportive land related documents were available this can be of great advantage. It helped Kosovo to finalise property restitution as a success story.

These findings from the collected evidence from Kosovo, as elaborated on in these three sections, suggest that these interventions in land administration can be recognised as elements that contributed to rebuilding the post-conflict society. Institutions were developed (both laws and bylaws), organisations were established (both at central and municipal level), capacity was built (both staff and equipment), performance was enhanced (both by vocational work instructions and guidance). Each of those actions was aimed at the creation of a sustainable land administration fundament. But how can we conceptualize this contribution better and link it to rebuilding the post-conflict society? To answer this question, we will discuss identified interventions in land administration reflecting on the theoretical aspects of the characteristics of post-conflict societies and see how those fit to the case of Kosovo.

\subsection{Post-conflict societies: observations in particular for Kosovo}

With reference to our findings before, we will structure those now in the framework of the three characteristics of Ball (2001) to come to grips with the role of housing and property rights and related land administration activities in addressing the characteristics of post-conflict Kosovo.

\section{Institutional weaknesses}

As has been said, in post-conflict contexts, states face institutional weaknesses like limited legitimacy of the state, a non-functioning political system and government structure, lack of adequately skilled professionals and an inadequate legal framework. The legitimacy of the state in Kosovo was fully realised by intervention of the international community and UNMIK (UN, 1999c), and UN-HABITAT's intervention in the land sector. Development and implementation of various policies, including land policies and implementation programmes, are considered to have had a large influence on the population in the sense of strengthening the legitimacy of the state 
(OECD, 2010). Establishment of organisations such as HPD, Housing and Property Rights Claim Commission and Kosovo Cadastral Agency as governmental entities contributed to the post-conflict government structure. Within the Kosovo Cadastre Support Programme a training programme was developed and employees were trained and educated (Onkalo et al., 2002). The example of Kosovo shows that first a specific organisation (the Agency) and implementing programmes (the Programme) with mandate for development of the housing and property rights and land administration were created, which later led to the development and adoption of the Land Administration Policy (2003) and the Law on Cadastre (UNMIK, 2003). From this we can derive that strengthening the institutional weaknesses in the land sector can be identified as elements that contributed to strengthening of the institutional weaknesses of post-conflict Kosovo.

\section{Social and economic problems}

Post-conflict countries also witness social and economic problems, such as death and injury, displacement, destroyed properties and infrastructure, hatred between people, loss of proof of identity and ownership. Addressing land issues in the UNMIK document (UN, 1999c) was a first step of involvement of specific housing and property rights and land administration in the improvement of the social and economic situation. This contributed to the solution of displacement and destroyed properties by providing cadastral products and services. The availability of land dispute resolution mechanisms (such as Housing and Property Directorate, the Housing and Property Claims Commission and the Kosovo Property Agency) supported the displaced people in settling the land disputes and reducing the social and security tensions (UNMIK, 2006). Furthermore, the creation of the Kosovo Cadastral Agency and the development of the land policy and land law resulted in an improvement of the land registration and land administration system in Kosovo (Smith, 2002). The development of the land administration function in Kosovo was supported by the Programme which contributed to sustainable development and supported the real property market. The success of the Programme suggests that it influenced the economic development and reduced social tensions. Development of land administration, specifically in the recovery of the land records that were removed, contributed to the service provision to all land-related sectors and significantly increased the security of rights. This is also seen as a support of the establishment of the land market within the overall economic development of Kosovo (Anderson and Onkalo, 2004). Interventions in housing and property rights and land administration, which contributed to the development of land associated sectors, lead us to identify them as elements that contributed to improving the social and economic problems of the post-conflict Kosovo. 


\section{Security problems}

One of the biggest challenges that post-conflict states face is the process of keeping the peace (Call and Cousens, 2008). The security situation in postconflict Kosovo could be described as tense and fragile, with a large international community and presence of the UN Security Forces for Kosovo (UN, 1999b). Addressing specific housing and property rights and land administration issues in UNMIK mission document (UN, 1999c) was their first involvement in support of the security situation. Land dispute resolution mechanisms, widely viewed as legitimate and pursued by the state, in general can contribute to a peace process (Unruh and Williams, 2013b). In Kosovo, land dispute resolution mechanisms and the organisations mentioned supported the settlement of the disputes over land and reduced conflict tensions. Therefore, interventions in housing and property rights and land administration can be identified as elements that supported reducing the security problems in post-conflict Kosovo.

\section{Scheduling the interventions}

In order to better illustrate the interventions in housing and property rights and land administration in Kosovo in the overall post-conflict state building process, the following table 3.1 is created as a result from the discussion. 
Table 3.1: Interventions in housing and property rights and land administration in post-conflict society - Kosovo

Interventions in housing and property rights and land administration in postconflict society - Kosovo

\begin{tabular}{|c|c|c|}
\hline $\begin{array}{l}\text { Institutional } \\
\text { Weaknesses }\end{array}$ & $\begin{array}{l}\text { Economic and Social } \\
\text { Problems }\end{array}$ & Security Problems \\
\hline $\begin{array}{l}\text { - Legitimacy of the } \\
\text { state (international } \\
\text { community and UN, } \\
\text { and UN-HABITAT for } \\
\text { the land sector) } \\
\text {-Political System } \\
\text {-Government } \\
\text { structure (authorities } \\
\text { dealing with land } \\
\text { claims, land } \\
\text { administration) } \\
\text {-Building Capacities in } \\
\text { housing and property } \\
\text { rights and land } \\
\text { administration } \\
\text {-Legal framework } \\
\text { (Land Policy, Land } \\
\text { Law, Improvements in } \\
\text { Land Registration) }\end{array}$ & $\begin{array}{l}\text {-Displacement (providing } \\
\text { cadastral products and } \\
\text { services) } \\
\text {-Destroyed properties and } \\
\text { infrastructure - providing } \\
\text { cadastre products and } \\
\text { services } \\
\text {-International community } \\
\text { and local authorities } \\
\text { participation/co-operation } \\
\text {-Citizen participation } \\
\text {-Recovery of land records } \\
\text {-Implementation } \\
\text { programmes (with aim to } \\
\text { uphold rule of law, reduce } \\
\text { conflicts, uncertainties and } \\
\text { support economic } \\
\text { development) }\end{array}$ & $\begin{array}{l}\text {-Including land in a } \\
\text { peace document (to } \\
\text { some degree supports } \\
\text { security situation as } \\
\text { well) } \\
\text {-Land dispute } \\
\text { resolution } \\
\text { (adjudication method) } \\
\text {-Displacement-land } \\
\text { relation (reducing } \\
\text { secondary conflicts) }\end{array}$ \\
\hline
\end{tabular}

\subsection{Conclusions and recommendations}

This chapter describes the conflict in Kosovo during various stages. Taking cognisance from general insights about the role of land in conflicts, we found that prior to the conflict the administration of land became part of discriminatory practises which fuelled ethnic tension dramatically. During the conflict we found that, apart from the most regrettable casualties, major parts of the housing stock were destroyed and property rights were severely violated. At technical level, in many cadastral offices the existing records were purposely taken away and transported to Belgrade. At the end of the conflict, we found that the land question was adequately included in the peace agreements, which led to involvement in land matters by UNMIK and the international community, in particular UN-HABITAT, which pushed the Kosovo Cadastre Support Programme. We found that during the phases of post-conflict development, of the emergency, the early recovery and the 
reconstruction phase, the international community, the UNMIK administration and local actors developed a system of housing and property rights and related land administration function. Developments were evident at an institutional and technical level, creating laws and bylaws, organisations, mandates, and offering building the capacities both in staff and equipment. In addition, an efficient mechanism was put in place to solve the numerous housing and property rights claimed by returning displaced citizens. It reveals that all this has created a good basis for further societal development.

All these developments brought us to the question whether housing and property rights and the related land administration functions might be seen as contributors to post-conflict state building. Our findings show that such a relationship is suggested. Therefore we discussed the interventions in housing and property rights and land administration from the perspective of a post-conflict societies theory, in a structure which we adopted from Ball (2001). Namely that contributions from housing and property rights and related land administration function that address post-conflict society issues can be grouped under the three characteristics, viz. improvement of institutional weaknesses, tackling social and economic problems, and enhancing the security situation. A first reconnaissance guides us to the conclusion that indeed the interventions in land administration made a positive contribution to addressing each of these three characteristics. That brings us to our recommendation, which is to further investigate this relationship and to see whether interventions in land administration as a whole contribute to the overall post-conflict state building. For now we expect that this positive relation exists, as this case already points that way. 


\section{Chapter 4}

Land administration for post-conflict contexts the case of Rwanda*

* This chapter is based on a book chapter published as:

Todorovski, D., Zevenbergen, J. and van der Molen, P., (2015). Land administration for post-conflict contexts. In J. Zevenbergen, W. de Vries and R. M. Bennett (Eds.), Advances in Responsible Land Administration (pp. 73-90). Boca Raton: CRC Press (Taylor \& Francis). 


\begin{abstract}
New thinking on post-conflict state building argues that land administration has a fundamental role to play. This relation is explored empirically through evaluating the post-conflict state building process in Rwanda. Rwanda witnessed violent conflicts in 1959 and in 1994. These conflicts resulted in mass displacement of population. Tackling issues relating to housing, land and property, and land administration was a very sensitive activity that could very easily have sparked new conflict. This chapter starts from the premise that core land administration elements can be built into broader state building processes; land sharing processes, village settlement projects, allocation of state land for the returnees, and land registration programs can be interrelated with other programs. The aim of this chapter is to increase the understanding of the characteristics of post-conflict state building with focus on housing, land and property and land administration. For the case of Rwanda, part of the answer lies in the historical background of the violent conflict, and in further understanding the original displacement and the challenges faced by returnees. Overcoming both types of predicaments adds to the overall process of post-conflict state-building, and the land administration development process in Rwanda.
\end{abstract}

\title{
4.1 Introduction
}

Conflict, land and property meet each other at every point in the conflict cycle, as experienced in many countries globally (Guterras 2009). A critical gap relating to the land component was identified a decade ago (OCHA, 2005). Awareness on the importance of addressing housing, land and property (HLP) in post-conflict contexts has increased since then, in both literature and practice. Despite this heightened awareness, knowledge of the nature of these problems and potential ways to address them is limited when it comes to state building (Kato, 2014). More specifically, a knowledge gap identified in the theory relates to the potential that land administration has within the post-conflict state building process (Todorovski et. al. 2012a).

New thinking on post-conflict state building argues that land administration has a particular role to play. Both practice and literature show that HLP and land administration are always negatively affected by conflict. Further, if they are not addressed appropriately in a post-conflict context they could spawn new disputes or even armed conflict (Lewis, 2004). This might complicate the fragile post conflict situation and the success of post-conflict state building efforts (Takeuchi, 2014). Therefore, post-conflict state building with a specific focus on the role of land needs better understanding.

The aim of this chapter is to recognize the characteristics of post-conflict state building, with a specific focus on HLP and land administration. The 
section on the theoretical perspective is based on the theory about: 1) the post-conflict state building; and 2) land in post-conflict contexts. The methodology section explains the research gap, presents the case of Rwanda, and describes the method of data collection. The case study of Rwanda provides evidence about developments regarding land in the post-conflict contexts. The discussion section identifies the relevant HLP and land administration issues for post-conflict state building. The discussion starts with the background factors of land, conflict and post-conflict contexts, and then continues in a structure of the main characteristics of war-torn societies: institutional weaknesses, social and economic problems, and serious security problems. This chapter finishes by articulating several key summary statements.

One country where the characteristics of post-conflict state building, focusing on HLP and land administration, can be further explored is Rwanda. Rwanda witnessed violent conflicts which resulted in large amounts of population displacement, and ended with one of the worst genocides known to recorded history. Displaced population started to return after the end of the conflict in 1994 when the security and humanitarian situation on the ground improved (Prunier, 1997). In a short period after the end of the conflict, land issues emerged for a large number of people. Tackling HLP and land administration was a very sensitive activity which required specific attention and an approach that corresponds to the local circumstances (Potel, 2014). Land sharing processes, allocation of state land, housing and village settlement for the returnees, and land administration developments are observed in this chapter within the broader post-conflict state building concept.

\subsection{Theoretical perspective}

This section, based on the available theory, provides an overview about the post-conflict state building and land in post-conflict contexts.

First, regarding post conflict state building, causes of armed conflicts are many, and stem from: territory, ideology, dynastic legitimacy, religion, language, ethnicity, self-determination, resources, markets, dominance, equality, and of course revenge (Heinz-Jürgen et al., 2006). Wars today kill fewer people than in the past, however greater numbers of civilians are exposed and vulnerable to violence. The United Nations (UN), reporting on the status of the force displacement worldwide, at the end of 2013 estimates 51.2 million displaced persons (UNHCR, 2014). According to FAO (2005), the violent conflict is over and post-conflict period starts when main hostilities have ceased, a peace agreement document (PAD) is signed, and international assistance can be provided. The post-conflict phases should not be understood as absolute, fixed, time-bound or having clear boundaries. 
However, scholars agree that a PAD is the foundation for the post-conflict state building period that follows.

After a PAD has been signed, the first challenge that post-conflict states face is the process of keeping peace, which is understood as a situation with absence of armed conflict, and at least a modicum of political process. Peace building is described as the whole-of-actions undertaken by international or national actors to institutionalize peace. Peace building requires some form of 'doing justice', and therefore application of the rule of law becomes a necessary perspective for looking at the given post-conflict environment (Call and Cousens, 2008).

To develop stability and socio-economic progress, it is recognized that the rule of law is critical to states emerging from a long period of conflict and misrule. It is important that the rule of law is not only provided for in the law but also is practiced by the officials of the state, allows participation of the citizens and is enforced by the courts (Rugege, 2013a).

State building is defined by OECD as:

"purposeful action to build capacity, institutions and legitimacy of the state in relation to an effective political process to negotiate the mutual demands between the state and societal groups" (OECD, 2008).

Fukuyama defines state building as:

"the creation of new government institutions and the strengthening of existing ones" (Fukuyama, 2004).

In post-conflict contexts the aim of state building is building effective systems and institutions of government; the establishment of trust and mutual accountability; notion of rights and obligations by citizens; and an political agenda aiming at the development of an inclusive state in support of an equitable economic, political and social order (Brahimi, 2007).

Ball (2001), observing further state building in post-conflict contexts, distinguishes three basic characteristics of war-torn societies. Firstly institutional weaknesses, like non-participatory and malfunctioning political and judicial systems, strong competition for power instead of attention to governing, a limited legitimacy of political leaders and no consensus on which way society should go. Secondly, economic and social problems: destroyed or decaying social and economic infrastructure, an increase of the illegal economy, people reverting to subsistence activities, hatred among population groups and, conflicts over land and property. Finally these societies have to 
cope with serious security problems: huge quantities of small arms freely circulating among the population, political influence of the armed forces, demobilization and disarmament (Ball, 2001).

In post-conflict situations international actors with available resources and skills should facilitate local processes and create a space for local actors which are the main work force. Together they should define and consolidate their policies in order to build responsive, resilient and robust institutions (Chesterman et al., 2005).

At the end of this chapter, under discussion, these characteristics of the wartorn societies developed by (Ball, 2001) are used a as a primary lens through which we will observe HLP and land administration within the post-conflict state building, because her views are widely accepted.

Second, regarding land in post conflict contexts, it is observed that although most violent conflicts are not 'caused' by conflicts over land per se, almost every major eruption of violent conflict has a land dimension (Putzel, 2009). EU-UN (2012) sees land as politically too sensitive or technically too complicated to be tackled early in the post-conflict period. Land issues always arise during the conflict but they become very complex immediately after the conflict. In a short period of time a mass population returns to their places of origin, and a common challenge for all post-conflict contexts is resettlement of the displaced population in an equitable process. Old properties and houses are usually destroyed, damaged or illegally occupied by secondary occupants (Leckie, 2000). The moment of return of people is critical and a possibility for eruption of new conflicts. Disputes over land are a very frequent problem in post-conflict settings. Thus land dispute resolution mechanisms are viewed as a necessary tool that should contribute to the peace process (Unruh, 2001).

Hollingsworth (2014) further developed the factors affecting land issues in the post-conflict period. Under 'institutional characteristics', factors affecting land are: international presence, UN, inappropriate legislation, (un)available land administration systems, lack of appropriately trained and skilled staff, and manipulation of the land records by politically powerful people. Under 'social and economic characteristics', displacement and destruction of houses and properties may be the most serious consequence of armed conflict, together with loss of proof of identity, proof of land rights and ownership. Under 'security characteristics', factors are: increased risk of secondary conflict in relation to land and conflicts between hosts and displaced population (Hollingsworth, 2014). 
Recognizing the important role that land is playing in post-conflict circumstances drives this research to explore the theory on how land is administered in these circumstances. UN/ECE's Land Administration Guidelines refer to land administration as:

"the process of determining, recording and disseminating information about tenure, value and use of land when implementing land management policies" (UN/ECE, 1996).

Land administration is the appropriate instrument for implementing national land policies. It performs a number of functions including: support in establishment of the land market, land use organization, setting land taxes, and management of state land. The goal of land administration processes is to support the implementation of land policies using the aspects of land management (van der Molen, 2002). According to Wehrmann (2005), the transfer of criteria of good governance to post conflict land policy and land management would likely provide a good basis for sustainable and lowconflict development. The establishment of such a framework is of crucial importance, especially in situations of post-conflict countries (Wehrmann, 2005).

Specific land related challenges that come up in the conflict and post-conflict contexts are: loss/destruction of properties, secondary occupations, landlessness, access to land, not functional land administration systems, forced transactions, emergency occupation of land and HLP rights (UNHABITAT, 2007). The most obvious negative impact for land administration follows from the loss of staff and records. Staff can be killed, (forced to) leave the area, or not be able or willing to return to their jobs within land administration systems (Zevenbergen and Burns, 2010). Incomplete, out of date, or contested land records can pose a threat to tenure security and overall peace situation. Issues about land records in post-conflict situations that require appropriate attention are: inadequate land records; fragmented responsibility for land records; lost, stolen, fraudulent and altered land records; and women and child's property and inheritance rights (UNHABITAT, 2009). HLP and land administration issues are always affected by the conflict and if not addressed properly they can cause secondary conflicts (Todorovski et al., 2012b). Experiences from other post-conflict contexts, including Kosovo and Timor-Leste, show specific land management and land administration activities were integrated in the peace agreement documents and UN operations (AD, 1999; UN, 1999c). 


\subsection{Methodology}

From the theoretical perspective it can be derived that the characteristics of post-conflict state building that relate to land, and more specifically land administration, need better understanding. The potential for land administration to contribute to the post-conflict state building process constitutes a clear knowledge gap (Figure 4.1).

conflicts and postconflict contexts
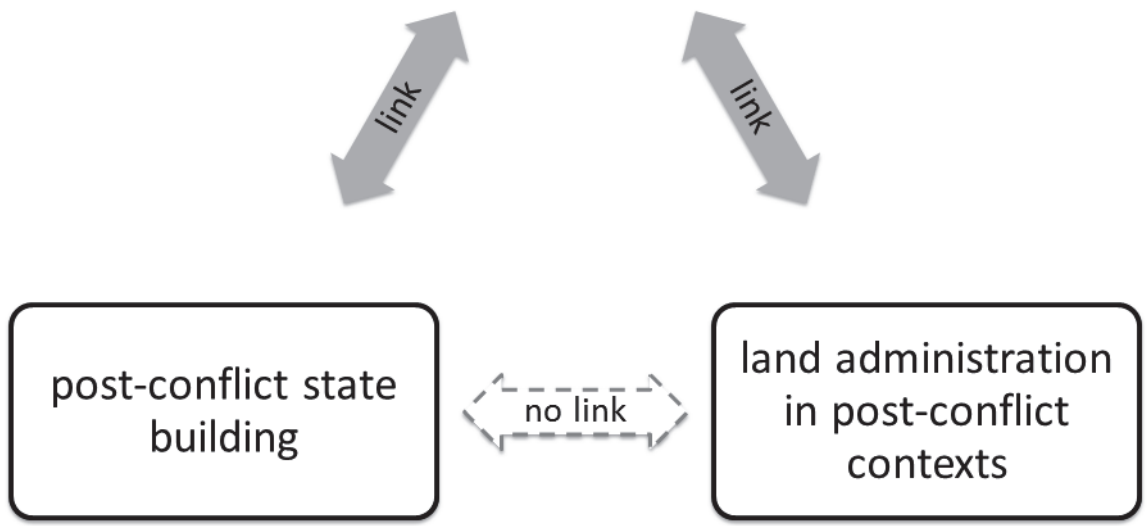

Figure 4.1: The gap in the knowledge (adopted from (Todorovski et al., 2012a))

The knowledge gap requires further study. The phenomenon is identifiable in contemporary practical contexts; however, the boundaries between the phenomenon and the context are not clear. Yin defines a case study as:

"an empirical inquiry that investigates a contemporary phenomenon within its real life context, especially when the boundaries between phenomenon and the context are not clearly evident" (Yin, 2003).

Accordingly, a case study with fieldwork was the most suitable approach to be applied to the work.

One of the cases where the gap in the knowledge can be further explored is Rwanda. Rwanda is a country that experienced violent conflicts and adopted developments in the area of post-conflict land administration within a broader post-conflict state building framework. More precisely, Eastern Rwanda is 
chosen as a case study area: in this area the majority of the refugees settled after their return. Data collection was executed in three separate fieldwork activities (Manirakiza, 2014; Potel, 2014; Songo, 2014). Selected locations in Eastern Rwanda for data collection were: Gasabo district (first fieldwork), Kayonza and Ngoma district (second fieldwork), and Rukara and Gahini sectors in Kayonza district (third fieldwork). Graphical representation of the selected study areas in Eastern Rwanda and the structure for selection of the interviewed informants is available in the Appendix of this research.

This study used primary data from the three fieldwork activities; secondary data collected from various organizations dealing with land issues, and was supported by a comprehensive literature review. The results section presents the findings from the collected Rwandan evidence with respect to 1) land and conflict relation; 2) HLP and land administration in post-conflict contexts; and 3 ) post-conflict state building (as they occurred during the conflict and postconflict period). The section discussion takes a more generalized approach and aims to develop more global understandings. The section starts with the background factors of the land, conflict and post-conflict contexts. Then the characteristics of post-conflict state building are elaborated, focusing on land in the structure of the characteristics of war-torn societies (Ball, 2001). Based on the discussions a table of characteristics of post-conflict state building focusing on the land is developed.

\subsection{Results}

Land, conflict and post-conflict contexts: Before and during the colonial era, land was used to divide the Rwandan population along ethnic lines. For the conflict in Rwanda, which finished in 1994, land issues were considered as its major cause: they were used as fuelling factor for the increase in ethnic tensions (Magnarella, 2005). Political representation and unresolved governance issues were mentioned as additional causes (Nyamwasa et al., 2010).

Among the characteristics of violent conflict, the most serious concerns were the number of people killed, widespread destruction of properties and infrastructure, and displacement. The first violent conflict in 1959 in Rwanda resulted in half a million refugees crossing the borders of the neighbouring countries. For the period after this conflict, the government of Rwanda used land as a political tool, redistributing the abandoned properties to their political followers and the military officers, causing illegal occupation by secondary occupants (Potel, 2014). The second violent conflict in Rwanda finished in 1994 with a genocide which caused more than one million dead people, a large number of IDPs and more than two and a half million refugees (Prunier, 1997). 
A peace treaty was signed in Arusha on 25 July 1993 (R. PAD, 1993). After signing the $P A D$, the security situation was fragile and tense, with a large military presence, presence of UN troops, and lots of sporadic conflicts: finally the genocide happened in the first half of 1994. Only after the victory of the Rwanda Patriotic Front (RPF), which took control over the whole country mid-July 1994, the security situation improved. Displaced people began returning. In process terms, this moment can be considered as the start of the post-conflict period. Within such a post-conflict period one can distinguish the emergency phase, early recovery phase, and the reconstruction phase (FAO, 2005). The emergency phase in post-conflict Rwandan from 1994 up to 1997 and was marked by unity and reconciliation activities. After the humanitarian crisis the main focus was on the provision of shelter, food and other basic living conditions for the mass returning population (Murekezi, 2012). Actors on the ground did not seem to understand the importance of land issues at this time: these were totally out of the focus of activities (Bruce, 2007). The early recovery phase can be seen as from 1997 until the end of 2002: this period involves the development of a legal framework, national policy developments, new government structures and strategies for their implementation. The period after 2003 can be observed as the reconstruction phase: it concerned implementation and execution of the legal frameworks, national policy and programs (Songo, 2014).

As identified in the theory, land starts to come to the forefront specifically during the emergency post-conflict phase, when people in mass return to their place of origin in a short period of time (Pantuliano, 2009; Unruh and Williams, 2013a). In Rwanda, a large number of people displaced during the first conflict returned immediately after the conflict ended in 1994. As per the recommendation in the PAD, the majority of returnees did not go back to their places of origin, instead they were allocated with the available state land - for example land in the national parks for housing and village settlements. The rest of the returnees went back and repossessed their old properties. The return continued until the end of 1996 and the last wave of one and a half million people which returned, were displaced persons from 1994. At the end of 1996 Rwanda witnessed a situation almost with two and a half million returnees which needed shelter. Land emerged as very sensitive issue which required a specific approach that corresponded to the local circumstances (Potel, 2014).

HLP and land administration in post-conflict contexts: Different solutions to the land related problems occur in the different post-conflict cases. Emergency measures such as creation of IDP camps and other settlements, on state public or private land, are de facto interventions in land 
management and land tenure (de Waal, 2009). The Arusha PAD in relation to land issues recommended:

"in order to promote social harmony and national reconciliation, refugees who left the country more than 10 years ago should not reclaim their original properties because they might have been occupied by other people' (R. PAD, 1993).

After the second wave of returnees, Rwanda had no alternative but to opt for land sharing between long-term secondary occupants and returnees, and distribution of state land for new village settlements (Takeuchi and Marara, 2009).

Land sharing was introduced with a purpose to ensure that this process is pursued in a fair manner, in order to maintain peace, harmony and reconciliation. When land sharing as a process started, this was done by a land committee formed on the very local level (cells) and by collaboration between the head of cell and the head of sector (Songo, 2014). As an example: if a certain property was repossessed by the displaced people from the 1959 conflict, the land committee would mediate and advise that those properties should be shared in a way that if a house was built before 1959, only the half of the property where the house was located remained in possession of the returnee from 1959; the other half went to the returnee from 1994. The land sharing was an informal process; written guidelines for implementation did not exist and the process was done in different ways in different parts of the country (Potel, 2014). Returnees, who failed to get land through sharing, were resettled on redistributed state land and via village settlement, through a program called 'Imidugudu'. Similar to land sharing, allocation of state land for housing and village settlement for returnees was supported by commune chiefs and members, and local authorities (Manirakiza, 2014).

With potentially so many overlapping and contradictory claims to land, disputes are likely to appear in post-conflict settings. To prevent these disagreements turning into (renewed) conflict, dispute resolution mechanisms are vital. Depending on the local circumstances, in some cases they might be solved via facilitation, mediation and in others via adjudication. In all cases, land dispute resolution mechanisms are viewed as a necessary tool that must contribute to the peace process (Unruh, 2001).

In Rwanda, although almost all returnees were settled one way or another, a number of land disputes were filed to the land claim commissions. The first instance was at the local administration authorities. If they failed to settle the land dispute, it was transferred to local arbitration committees, so called 
'Abunzi'. Finally the highest instance for settling the land disputes, were the courts (Songo, 2014).

In the procedures of solving the land disputes, having land records available appeared to be very important. In general, land records in post-conflict contexts are vulnerable and always negatively affected during the conflict. Land records in post-conflict environment can be: damaged, stolen, lost, manipulated by powerful parties (groups), partly or fully destroyed, moved to third country or even be a target for violent attack (like in 1999 in TimorLeste). Fully paper based systems are even more vulnerable (Todorovski, 2011). In Rwanda, after the conflict ended, it is believed that around $10 \%$ of all parcels had formal land records; an example from the Gassabo District shows that only for $7.7 \%$ of the parcels land records existed. A small number of existing land records were destroyed or manipulated as a consequence of the conflict in the period after the conflict. In about $90 \%$ of the territory of Rwanda, customary law was practiced, therefore informal evidence such as oral witnesses, correspondence letters and two party sales agreements, were socially accepted by both population and authorities. Availability of land records or other proof of ownership, when existing, appeared to be beneficial for the process of settling land disputes and claims (Manirakiza, 2014).

Observing land administration in Rwanda, it is evident that since 1952, private ownership was introduced. In practice, the written law was applied to a small number of people, especially in urban areas, trading centers, to foreign investors, and religious institutions. Similar to the colonial period, in the post-colonial period, the dual tenure system continued in practice. In the post conflict period, Rwanda suffered from gaps in land laws and related texts in other land related laws (Rurangwa, 2004). The first developments of postconflict land administration could be seen with the establishment of the Ministry of Lands in 1999 which was assigned a mandate to develop and draft the new Land Policy in the period 1999-2003 (Songo, 2014). Based on the newly adopted Land Policy in 2004, Rwanda embarked on a major land reform program, with the perspective that the whole country should be brought under one formal land administration system. Adaptation of the land policy lead to the new Organic Land Laws being adopted in 2005, and to the establishment of organizations that had mandate for its enforcement (Potel, 2014).

Actors involved in the development of the post-conflict land administration in Rwanda can be categorized in four categories: government, citizens, advocacy groups and international organisations. Each of these actors had their particular role in the land administration development. On the government side, there were authorities at central and on local level. Initially, after the conflict, the Ministry of Lands was formed. Other Ministries which 
became involved at central level were the Ministry of Agriculture (responsible to administer the rural land in Rwanda), the Ministry of Infrastructure, and the Ministry of Local Government (these two ministries were responsible for administering the urban land in Rwanda). Currently, the Rwanda Natural Resources Agency (RNRA) is responsible for land administration in Rwanda with mandates on central and on district level (Songo, 2014).

From these developments, as described and evaluated in the case studies, (Manirakiza, 2014; Potel, 2014; Songo, 2014) we can carefully conclude that in Rwanda, the post-conflict context fostered the development of the HLP and land administration.

The Land Tenure Regularization (LTR) program started in 2008, aiming to increase agricultural productivity (through the consolidation of land holdings and greater incentives to invest in agriculture), and hence enhance economic development and reduce of social tension (Gov. of Rwanda, 2008). The LTR until December 2013 registered all the land in Rwanda (10.3 million parcels) for the first time. It involved a one-off, low-cost, community-based process of LTR. The case study of Gillingham and Bruckle (2014) identified as key success factors: political commitment, a detailed LTR approach developed in an earlier phase of the program, and the programs flexibility. The case study identified some points that need attention in the longer term: further development of the land administration system, as well as financial and judicial sustainability are required (Gillingham and Buckle, 2014).

Post-conflict state building: The background factors which should be taken into account in order to understand Rwanda's post-conflict state building are: the fact that RPF gained a complete military victory, and that the RPF used the genocide for its own legitimacy-building. For states emerging from conflict, initially there are two international norms that support capacity and legitimacy of the state: achieving political stability and the rule of law. In the Rwandan case, political stability was realized by military operations and other institutional arrangements, some of whose contribution to the rule of law were questionable (Takeuchi, 2011). The policy of 'land sharing' can be seen as a process, allocating land to the returnees, with the aim of strengthening the political basis of the government. The provision of the housing and village settlement program 'Imidugudu' can be understood in the same vein (Hilhorst and van Leeuwen, 2000; Huggins, 2009). Tackling the sensitive land issues as the Rwandan government did, appeared to have a positive influence to the overall security situation in Rwanda, as our case studies show (Songo, 20014). In having significant influence over the population, the new Land Policy is deeply effecting the legitimacy of the state (OECD, 2010). 
According to the case study (Songo, 2014), developments in the land sector, as well as in the legal framework, as practiced by state officials, citizen participation and enforcements by the courts, contributed to the realization of the rule of law in Rwanda. Decentralization of authority and various state development programs (like the LTR program) have had a positive effect in realization of the rule of law in Rwanda (Rugege, 2013a).

Chesterman et. al. (2005) argue that building institutions that are legitimate and sustainable is crucial for developing states that are failing states, and states emerging from conflicts. The case results showed that all activities and developments that happened in Rwanda were very much based on the country's specific circumstances: developments in the land sector were not an exception. Building institutions in the land sector was evident in the legal framework, and in the creation of authorities with specific mandates for implementation of the policies and programs (Songo, 2014).

The genocide had a very negative social effect on Rwanda and this was tackled with promotion of peace, social harmony and national reconciliation (R. PAD, 1993). Another identified socio-economic form of legitimacy-building from the case of Rwanda is that the state efficiently responded to people's expectations. Takeuchi (2011) acknowledges that post-conflict Rwanda has performed fairly well in terms of providing security and other basic services. Land services could be added to Takeuchi's (2011) acknowledgements: state land was redistributed for housing and village resettlement; and the LTR program provided for whole-of-country land registration. In addition to the improvement of the social sector, high economic growth may have contributed to ameliorating people's living standards (Takeuchi, 2011).

Land dispute resolution institutions are also considered to contribute to the overall security situation in post-conflict contexts (Unruh, 2001). Land claim commissions and their contribution to the security situation in Rwanda have been mentioned previously.

\subsection{Discussion}

This section focuses on identifying the characteristics of post-conflict state building that relate to HLP and land administration. First, the background factors of the land, conflict and post-conflict context are covered. Following this, elaboration of the characteristics of post-conflict state building is undertaken, with focus on the land. This is done in using the structure of the characteristics of war-torn societies (Ball, 2001). The aim is to illustrate and increase the understanding of HLP and land administration and how they developed in post-conflict state building. Use is made of the findings from the Rwandan case. A table of characteristics of post-conflict state building, focusing on HLP and land administration, is finally presented. 
Background factors of the land, conflict and post-conflict context: Causes of violent conflicts are many and varied. In the case of Rwanda land issues were considered a major cause used to increase ethnic division leading to violent conflict (Magnarella, 2005). This is an important fact to be considered, because land therefore requires attention in post-conflict state building activities; as was the case in Rwanda. The most serious concerns from a violent conflict are: number of people killed, destruction of properties and infrastructure, and displacement. The conflict in Rwanda ended with a genocide in which one million people died (Prunier, 1997), but with no substantial destruction of houses and infrastructure. The cases of Kosovo and Timor-Leste are examples where PADs contained specific land management and land administration activities integrated in the post-conflict UN operations (AD, 1999; UN, 1999c). In a majority of other cases, unfortunately as well as in the case of Rwanda (Bruce, 2007), PADs had very limited attention to land. This could be a reason for later developments in the reconstruction phase of the post-conflict period. All violent conflicts result in displacement of population (Rwanda had more than two and a half million refugees) which is an alarming issue for the host countries, for the UN, and the international community. Displacement and the destruction of properties have large impacts on the land and its administration (Hollingsworth, 2014): together they are a critical issue in recent conflict and post-conflict environments.

In the early stages of the post-conflict period in Rwanda, the political stability was realized with military intervention (Takeuchi, 2011). Taking a longer term view, developments of the HLP and land administration contribute to political stability integrated in the broader National Development Strategy. Recognizing that the rule-of-law is critical to states emerging from a conflict (Rugege, 2013a), it was found that the developments of legal framework, the establishment of organizations, and the participation of the citizens in the land sector (Songo, 2014) contributed to the realization of the rule of law in the case of Rwanda.

Institutional weaknesses: In post-conflict contexts, states face institutional weaknesses like limited legitimacy of the state, a non-functioning political system and government structure, and an inadequate legal framework. In Rwanda it was found that building the legitimacy of the state initially was based on the land sharing policy, allocation of state land, and housing and village settlements (Hilhorst and van Leeuwen, 2000; Huggins, 2009). Development and implementation of various policies, including land policies, is considered to have a large influence over the population, in sense of strengthening the legitimacy of the state (OECD, 2010). Establishment of organizations such as land claim commissions, different Ministries responsible for land, and RNRA in Rwanda as governmental entities, contributed to the 
post-conflict government structure. The example of Rwanda shows that first a land policy was developed, which later lead to the development and adoption of land laws and appointment of a specific organization with a mandate for enforcement of the law and land policy (Songo, 2014). From this we can derive that strengthening the institutional weaknesses in the land sector is clearly important for Rwanda.

Social and economic problems: Post-conflict contexts witness social and economic problems such as: death and injury, displacement, destroyed properties and infrastructure, hatred between ethnic groups, loss of proof of identity, and ownership. The genocide in Rwanda created a very negative social situation, which was addressed by the promotion of peace, harmony and national reconciliation. Addressing land issues in the peace agreement document (R. PAD, 1993) in a context of social harmony and national reconciliation was a first step of involvement of HLP and land administration in the improvement of the social and economic situation. This commitment, from the PAD, was further identified when local authorities supported the displaced people, and assisted in the land sharing and village settlement processes. Where it was required, sector authorities mediated and advised on the land sharing and distribution of the state land between returnees from different periods. This mediation is seen as a successful land dispute tool, and if they failed then the official three level land claim commissions were involved (Potel, 2014). Development of the land policy and land law resulted in improvement of the land registration and land administration system in Rwanda. Development of the land administration in Rwanda was supported by the LTR program which contributed to sustainable development and supported the real property market. Initial success of the LTR program suggests that it influenced an increase of the agricultural productivity, economic development and reduced social tensions. Development of land administration contributed to the service provision to all land related sectors and significantly increased the security of the land rights (Gillingham and Buckle, 2014). This is also seen as a support of the establishment of the land market within the overall economic development of Rwanda. Acknowledging developments in the HLP and land administration, which contributed to the development of land related sectors, leads to the identification of them as elements of social and economic importance in post-conflict Rwanda.

Security problems: The first challenge that post-conflict states face is the process of keeping the peace (Call and Cousens, 2008). The security situation in post-conflict Rwanda could be described as tense and fragile, with a large military and UN presence (Prunier, 1997; Takeuchi, 2011). Land dispute resolution mechanisms, widely viewed as legitimate and pursued by the state, in general can contribute to a peace process (Unruh, 2001). In Rwanda, mediation and advice by sector authorities on the land sharing and 
distribution of state land, supported by settling the land disputes, reduced conflict tensions over land significantly. The three level land claim commissions were available as official authorities in Rwanda (Manirakiza, 2014). Addressing land in the PAD (R. PAD, 1993), facilitating land redistribution, land sharing and the village settlement program by the community members and local authorities, and resolving the land disputes and claims (Potel, 2014), could therefore be identified as elements of the security situation in post-conflict Rwanda.

As a synthesis of the discussion, Table 4.1 illustrates the identified elements of HLP and land administration in Rwanda, and their fit within the overall post-conflict state building.

Table 4.1: Characteristics of post-conflict state building focusing on the role of HLP and land administration - the case of Rwanda

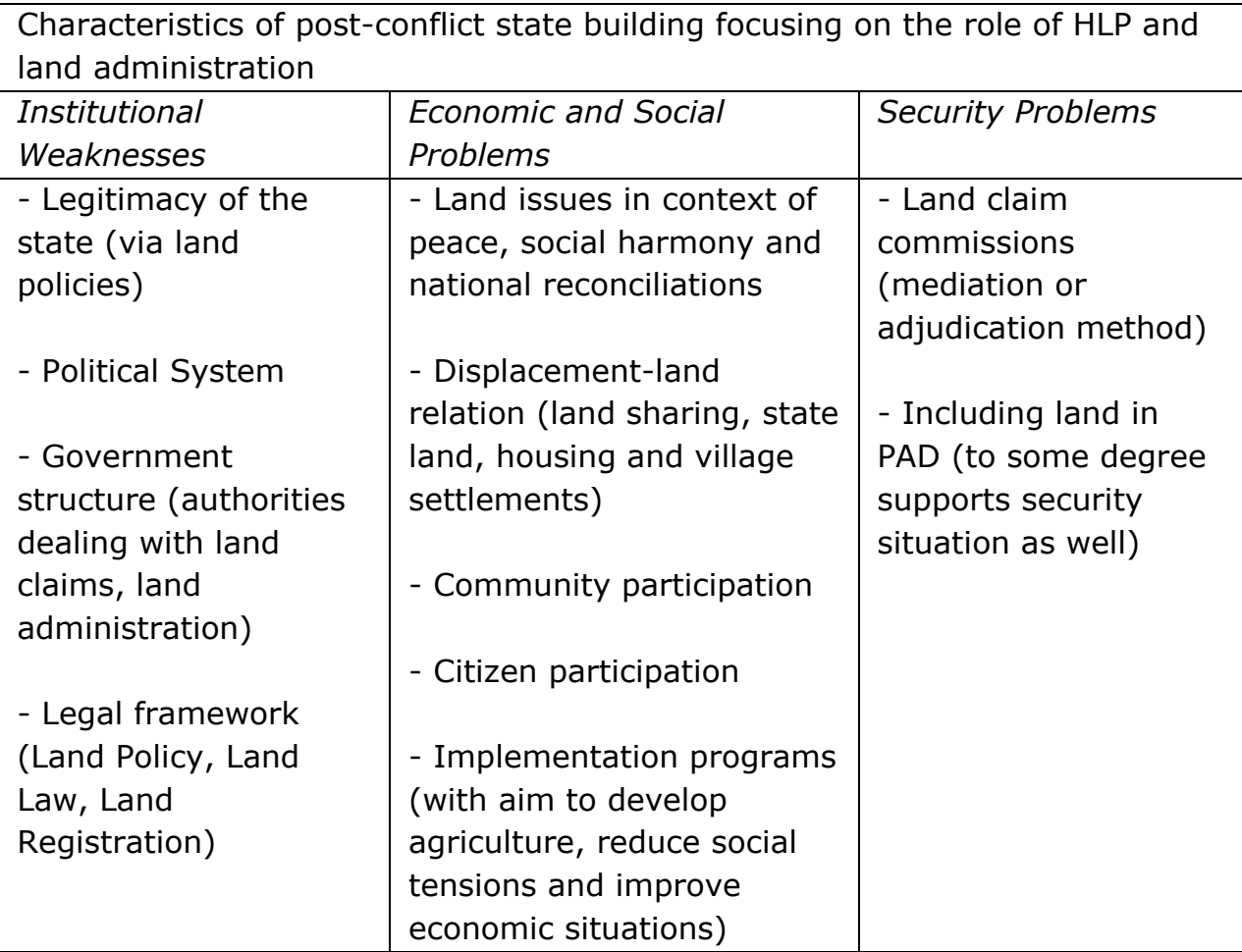

\subsection{Conclusions}

This chapter aimed to recognize the characteristics of post-conflict state building, with a focus on HLP and land administration. This was done initially by identifying the background land-conflict factors and then using the characteristics of war-torn societies (Ball, 2001) as a framework for understanding observations made on HLP and land administration within 
post-conflict state building. Based on the contributions of literature and the presented findings for Rwanda, the following generalized conclusions are made.

As a background factor, land can be a one of the many causes for the conflict, but in some cases land is considered the major cause for the violent conflict. Therefore, land must always be considered as part of post-conflict state building activities. Addressing land in general, and specifically land management and land administration, in a PAD, and within UN operations, is beneficial, and it can result in improvements to land administration in earlier phases of the post-conflict period. However, HLP and land administration tend to contribute to political stability in the longer term and should be integrated in the broader National Development Strategy. Development of the legal framework, practiced by state officials, with citizen participation, and with enforcement of the law via courts, promotes rule-of-law in postconflict contexts. Similar developments in the land sector also contribute to this promotion of the rule-of-law.

One of the characteristics of the post-conflict state building is institutional weaknesses which could initially be addressed by applying specific land policies. Land policies can have significant influence over the population and they contribute toward creating legitimacy for the post-conflict state. Usually a 'Ministry of Lands' or similar governmental authority has a mandate to develop the land policy. Land policies lead to the development of the land laws and indicate organization(s) for enforcement of the policy and the law. Examples are land administration organizations and land claim commissions within the governmental structure. Implementation of the legal frameworks is most successful via appropriate implementation programs.

Another characteristic of the post-conflict state building activities are ongoing social and economic problems, where the most negative social effects are death and injury. These problems can be tackled with promotion of peace, social harmony and reconciliation. Land related issues, specifically in relation to a displaced population, could be addressed in the same manner. Mediation and advice in allocation of land to returnees, or land policies supported by local authorities, and official land claim commissions for settling land disputes, can support the social situation. Improvement of the service provision, within the land administration sector, via appropriate implementation programs, increases the security in land rights. A supportive implementation program in the land administration can support the development of a land market and the overall economic situation of a postconflict state. 
By definition, the security situation is always likely to be problematic in a post-conflict context. Land dispute resolution institutions are accepted as contributors to the overall security in a post-conflict situation. Including land dispute resolution institutions in the PAD and in the UN operational guides, can speed up the development of such institutions. Availability of mediation methods or official land dispute resolution institutions is recognized as an element that supports the security situation after the conflict.

Based on the findings of this study it is concluded that the potential of HLP and land administration have been identified, and indeed they play a particular role in post-conflict state building. Table 4.1 shows the characteristics of post-conflict state building and how HLP and land administration are applied for a specific context. Table 4.1 can be applied in other cases (as it can be seen in Table 3.2 in Chapter 3) and illustrates the potential of the HLP and land administration in other post-conflict state building cases. 


\section{Chapter 5}

\section{How interventions in land administration facilitate post-conflict state building?*}

\footnotetext{
* This chapter is based on a journal paper submitted as:

Todorovski, D., Zevenbergen, J. and van der Molen, P., (2015). How interventions in land administration facilitate post-conflict state building? International Journal of Peace and Development Studies. [Under review]
} 


\begin{abstract}
In earlier research in the area of land administration in conflict and postconflict contexts the relation between land administration and state building was recognised. This chapter aims at increasing the understanding of this relation. Available literature is explored to learn more about the concepts of state building, and land and its administration in post-conflict contexts. The most suitable methodology to increase the understanding of the relation under investigation here is a qualitative research approach using a multiple case study with fieldwork for data collection. In doing so, the cases of Kosovo and Rwanda (see chapters 3 and 4) are used as the two main case studies, and the cases of Mozambique, Cambodia and Timor-Leste are used as supportive case studies. The empirical data collected based on fieldwork from the main case studies and data collected through literature review from the supportive case studies has been used to derive lessons learned from those cases. For analyses of the collected data a three-dimensional matrix has been generated, which supported by the findings from our cases results in analytical generalisation of the relation. Discussions and analysis of collected evidence indicate how interventions in land administration facilitate postconflict state building.
\end{abstract}

\title{
5.1 Introduction
}

Land and its administration are always negatively affected by armed conflict, and if they are not addressed properly in the post-conflict period they can be a reason for new disputes or a cause for renewed armed conflict. These issues become more complex after the end of the conflict, when the postconflict contexts are characterized by: human casualties, destroyed infrastructure and houses, and displaced population. Awareness about the importance of addressing land in such a circumstance has increased in the last 15 years, both in literature and in practice. A research in the area of land administration in conflict and post-conflict contexts has identified that a relation exists between land administration and state building (chapters 3 and 4). Therefore, the aim of this chapter is to increase the understanding of this relation. This chapter is guided by the following research question: how interventions in land administration facilitate post-conflict state building?

In the following section the theoretical perspectives on the topics of state building and of land and its administration in conflict and post-conflict contexts are explored based on literature. The methodology section is elaborating the methodology chosen, the strategy for case selection and the selected cases which will be used to increase the understanding of the identified relation. The 'Lessons learned from the cases' section presents the analysed empirical data and discussions from two main case studies, with support from the analyses of data from literature on three additional 
supportive case studies. In the 'Discussions and analyses' section the correlating analysis is performed and represented in a three-dimensional matrix. Lessons learned from the cases together with the matrix are used to increase the understanding of the relation between land administration and state building in post-conflict contexts. Based on this, the chapter ends with drawing conclusions and proofs about the identified relation.

\subsection{State building, land and its administration in post-conflict contexts}

In order to better understand the relation between (1) state building and (2) land and its administration in post-conflict contexts, a theoretical perspective on these two topics is elaborated from the available literature.

\section{State building in post-conflict contexts}

Peace building: After the end of an armed conflict, sometimes a new state is formed or an old one resurrects from the ruins of conflict; both have to go through the process of rebuilding the post-conflict state. The rebuilding of the post-conflict states is a complex and delicate undertaking (Brahimi, 2007). The first challenge in rebuilding the post-conflict states is the process of keeping the peace, the so-called peace building process. Peace building processes are a risky and sensitive affair, involving many stakeholders, where the situation on the ground is uncertain and changes on a daily basis. Especially in the early stages of the post-conflict period, possibilities of eruption of a new conflict are a big threat to the peace. Peace building is a relatively new concept that has been further developed since its first introduction as a UN tool in the 'An agenda for peace' document. At the beginning, UN activities were focusing on peace-making and peace-keeping, basically security-related actions (UN, 1992).

It is believed that the so called 'Brahimi Report' (2000) improved the effectiveness of UN peace-keeping operation and since then a more inclusive peace building concept has been introduced (UN, 2000). Moreover, the Brahimi report inspired the creation of the Peacebuilding Commission during the 2005 World Summit as a result of its recommendation to establish a body capable of dealing with transitional administrations and failing states (Stahn, 2005). Call and Cousens (2008) define peace building as 'actions undertaken by international or national actors to institutionalize peace, understood as the absence of armed conflict and at least a modicum of political process' (Call and Cousens, 2008). Nowadays, their views are widely accepted as is done in this chapter. The process of peace building requires some form of 'doing justice' and therefore the application of the rule of law becomes a necessary perspective for looking at the given post-conflict environment. To develop 
stability and long lasting peace, it is recognized that the rule of law is critical to states emerging from a long period of conflict and misrule. It is important that the rule of law is not only provided for in the law but is also practised by the officials of the state, allows participation of the citizens, and is enforced by the courts (Rugege, 2013b).

In post-conflict situations, international actors with available resources and skills should facilitate local processes and create a space for local actors, who are the main workforce. Together, they should define and consolidate their policies to build responsive, resilient, and robust institutions (Chesterman et al., 2005).

The mid-1990s have seen a change in peace building activities, where instead of mainly focusing on security activities, increased involvement of the development actors and donors is experienced which included institutional building (Takeuchi, 2014). Some scholars examined specifically the institution building during periods of colonial occupations and after the conflicts, deriving lessons learned for understanding contemporary state building (Matsuzaki, 2011). After the 9/11 event, security and development are being linked and the concept of rebuilding the post-conflict states is seen as a holistic approach - post-conflict state building (Scott, 2007).

State building: State building is a truly inter-disciplinary topic, which draws interest and discussions from the specific scientific fields. Interestingly the literature on state building has been largely driven by the international relations and political science fields. From the security and peace-keeping literature, the terms 'peace building' and 'state building', are considered the same, and they occur in post-conflict contexts (Scott, 2007). Fukuyama defines state building as 'the creation of new government institutions and the strengthening of existing ones' (Fukuyama, 2004). This research focuses on the development of the land administration in post-conflict contexts. Following the logic of development studies the definition of state building from the Organisation for Economic Co-operation and Development has been adopted: a purposeful action to build capacity, institutions and legitimacy of the state in relation to an effective political process to negotiate the mutual demands between the state and societal groups (OECD, 2008). Both practitioners and literature in development studies are guided by this definition as well (Dabo et al., 2010; Takeuchi, 2014).

Post-conflict state building: Although there is no generally accepted list of 'core functional domains' of the state, which should be developed in the postconflict period (mainly because each post-conflict state is unique in itself), several concepts appear in literature. Addressing post-conflict state building, CSIS/AUSA (2002) produced a framework of four core 'pillars' including: 
security, justice and reconciliation, economic and social well-being, and governance and participation (CSIS/AUSA, 2002). This concept has been adopted by New Partnership for Africa's Development (NEPAD, 2005) while designing their own post-conflict state building framework adding to the list the fifth 'pillar': co-ordination, management and resources mobilization. Emphasizing on the administrative aspect of post-conflict state building, Ammitzbøll and Blair (2011) presented a framework of five core state functions or 'domains': security, political governance, economic governance, administrative governance and juridical governance. In another variant Ghani et al. (2006) constructed a list of ten essential state functions.

Van Gennip (2005) elaborated in greater detail on the four 'pillars' version from CSIS/AUSA as follows: 'security or the establishment of a safe and secure environment through the establishment of legitimate and stable security institutions; justice and reconciliation which incorporates an impartial and accountable legal system, a means to deal with past and current crimes, and a humane prison system; economic and social well-being achieved through the provision of emergency relief, restoration of basic services, laying the foundation for a viable economy and sustainable development; and finally, governance and participation, by building viable constitutional structures, capacity building in state institutions and public administration and the nurturing of an articulated civil society capable of participating in governance and relieving the state of some of its myriad burdens' (van Gennip, 2005). Later, his concept was adopted by NATO Parliamentary Assembly's Economic and Security Commission. What is common for these post-conflict state building concepts is that they are developed from or for the security organizations' perspective.

Observing rebuilding states in post-conflict contexts, Ball (2001) distinguishes three basic characteristics of war-torn societies. The first characteristic comprises institutional weaknesses, like non-participatory and malfunctioning political and judicial systems, strong competition for power instead of attention to governing, a limited legitimacy of political leaders, and no consensus on which way society should go. The second characteristic comprises economic and social problems: displacement, destroyed or decaying economic and social infrastructure, an increase of the illegal economy, people reverting to subsistence activities, hatred among population groups, and tensions and disputes over land and property. Finally, these societies have to cope with serious security problems: huge quantities of small arms freely circulating among the population, political influence of the armed forces, demobilization and disarmament, and - significant for the issue under review here - conflicts over land and property (Ball, 2001). 
If one observes the definitions of peace building (Call and Cousens, 2008) and the definition of state building together (OECD, 2008), one can also come to another concept of post-conflict state building. Where basic elements would be: security, strengthening of the capacities of institutions and legitimacy of the state, and improvement of the society citizen relationship the economic and social development. The concept generated here and the overview of the concepts of post-conflict state building showed that they share a similar conceptual reasoning, and have a lot of similarities and use a similar terminology.

Having this overview of the concepts and mainly guided by Ball (2001), because her concept is most acceptable and logical to link to the collected data from our case studies, we apply those three characteristics. Based on elements identified by Ball (2001) with adding a few extra elements from the other concepts that we investigate in this research, we further detail each of those characteristics with thirteen elements in Table 5.1: A framework for rebuilding post-conflict states. In the section 'Discussions and analyses' the contents of Table 5.1 will be used as a theoretical proposition for the correlating analyses in order to support the discussion of findings from the main case studies.

Table 5.1: A framework for rebuilding a post-conflict state

\begin{tabular}{|l|l|l|}
\hline $\begin{array}{l}\text { Institutional } \\
\text { Weaknesses }\end{array}$ & Economic and Social Problems & Security Problems \\
\hline - Legitimacy of the & - Displacement & - Peace and \\
state / political & - Destroyed properties and & reconciliation \\
leaders & infrastructure & - Conflicts over land \\
- Political system & - Participation/Cooperation & and property \\
- Government & International community and & \\
structure & local authorities & \\
- Legal framework & - Citizen participation & \\
(Policies, Law and & - Low economic activities & \\
Administration) & - Lost/destroyed state records & \\
- Building Capacities & & \\
\hline
\end{tabular}

One key issue in this peace building and state building conundrum is land and property, mentioned in second and third characteristic of war-torn societies (Ball, 2001), which form a basis for people's lives in many ways. Land and property issues provide a policy space in which public institutions and local people aim to improve their daily lives (Kato, 2014). It is therefore evident that tackling land and property problems in post-conflict situations cannot be done in isolation but better be done as an integral part of state building (Takeuchi et al., 2014). 


\section{Land and its administration in post-conflict contexts}

During a conflict people are killed, buildings and physical infrastructure are destroyed, legal frameworks are set aside, public registers are destroyed, markets do not function any more, properties are taken, and lands are occupied (van der Molen and Lemmen, 2004). Destruction of infrastructure and properties, and displacement have large impacts on land and its administration in such contexts (Hollingsworth, 2014; Takeuchi et al., 2014).These issues become more complex after the end of the conflict when people in large numbers come back to their places of origin and usually find their houses and properties burned, destroyed, or illegally occupied by secondary occupants (Leckie, 2000; Pantuliano, 2009). This is a critical moment of the post-conflict period and these problems could spawn disputes over land and properties or even a new armed conflict (Lewis, 2004). Other land-related issues that come up in conflict and post-conflict contexts are: landlessness, access to land, non-functional land administration systems, forced transactions, emergency occupation of land, and housing and property rights (Zevenbergen and Burns, 2010). Disputes and claims over land are a very frequent problem in post-conflict settings. Therefore, land dispute resolution mechanisms are viewed as a conditional tool for a good peace process (Unruh, 2001; Unruh and Williams, 2013a). In the majority of cases, land is seen as politically too sensitive or technically too complicated to be tackled in the early stages of the post-conflict period (EU-UN, 2012).

Land plays a specific role in conflict and post-conflict contexts, therefore it is important to acknowledge how land is administered in these circumstances. Land administration is considered as the process of determining, recording and disseminating information about tenure, value and use of land when implementing land management policies' (UN/ECE, 1996). Land administration is the appropriate instrument for implementing national land policies, with a number of functions like support for the establishment of a land market, land use planning, land tax administration and management of state land (van der Molen, 2002). Post-conflict situations lead to a dysfunctional land administration system characterised by: limited prioritisation of land policy, discriminatory land law, poor institutional and regulatory framework that allows the grabbing of public and private land by powerful individuals and groups, poor management information systems for updating records as well as weak state capacity that is incapable of helping internally displaced people and refugees (Augustinus and Barry, 2006). The most obvious blow for land administration in post-conflict contexts follows from the loss of staff and records. Staff can be killed, (forced to) leave the area or not be able or willing to return to their jobs within land administration systems (Zevenbergen and Burns, 2010). Incomplete, out of date or contested land records can pose a threat to tenure security and the overall 
peace situation. The issues about land records in a post-conflict situations that require appropriate attention are: inadequate land records, fragmented responsibility for land records, lost, stolen, fraudulent and altered land records, and woman and children's property and inheritance rights (Todorovski, 2011).

Housing and property rights and land administration are always negatively affected by conflicts and if not addressed properly in a post-conflict context they could be a reason for new disputes or causes for renewed armed conflict (Todorovski et al., 2012b). Looking back in history, the peace agreements contained only limited references to land issues, mainly in relation to displaced people and their basic human right to return to their properties with dignity (examples: (PAD, 1991, 1992; R. PAD, 1993)). Only in the cases of Kosovo and Timor-Leste specific land management and land administration activities were integrated in the peace agreement and UN operations (AD, 1999; UN, 1999c). As seen in practice and literature, there is an identified need that land issues are put on the agenda of the international community and that they are tackled in peace agreement documents or national land policy of the states emerging from a conflict (EU-UN, 2012).

In order to appropriately tackle the land and property problems in postconflict contexts, it is necessary to be aware of the fragility of the particular post-conflict state. Addressing land and land administration in such contexts should therefore be coherent with the state building efforts. International engagements on state building are highlighting two important areas of this process: supporting the legitimacy and accountability of the states and strengthening the capability of the state to fulfil their core functions (OECD, 2008). Takeuchi et al. (2014) argue that tackling land and property problems has important implications for post-conflict state building in general, and particularly for legitimacy building and that regulating land and property rights and land administration is one of the fundamental functions of the state.

\subsection{Methodology}

This chapter is focusing on increasing the understanding in the relation land administration and state building in post-conflict contexts. Observing this phenomenon we consider it a contemporary practice context, where, the boundaries between the phenomenon and the context are not clear. Yin (2003) defines a case study as: 'an empirical inquiry that investigates a contemporary phenomenon within its real life context, especially when the boundaries between phenomenon and the context are not clearly evident'. The qualitative research methodology examines the how, what and why of various research topics (Thomas, 2003). Therefore, the qualitative methodology using multiple case studies is most suitable for this research. 
In this chapter we are answering the 'why' question based on the identified concepts in the theory that land and land administration are always negatively affected by conflicts and during the post-conflict period. If these issues are not addressed properly they could be the cause for a new conflict instead of supporting the rebuilding of the post-conflict state. Answering the 'what' and 'how' questions is done in order to identify, what and how the phenomenon of land administration supported post-conflict state building in our cases. These answers provide the evidence for the further analyses in this chapter.

The findings or results from the single study are to follow a process of analytic generalization, where case studies results are generalizable to theoretical propositions. Analytical generalisation is recommended for multiple case studies - observing the same phenomena in different case (Yin, 2010). To strengthen the relevance of analytical generalisation, it is important to make a right selection of the case(s) to be investigated. The phenomenon under research here is multidisciplinary, with different characteristics of each discipline, and different phases of developments in different cases. Therefore a 'strategy of maximum variance' (Hutjes and van Buuren, 1992) for cases selection is most suitable. This strategy includes the variety of phase development of the phenomenon that is explored. In this regard, selection of the cases is based on the presence of specific features of: conflict and post-conflict contexts, land administration in post-conflict contexts and post-conflict state building in each case. About conflict and post-conflict contexts specific issues related to refugees and internally displaced persons (IDPs) should be present in the main cases. Concerning land administration in post-conflict contexts characteristics like land administration systems with or without land records and presence or absence of land professionals should be present. Regarding the subject of post-conflict state building in the main cases, a situation with a newly formed state after the conflict and the existing one coming out from the conflict should be present in main cases. Two main case studies are selected to be investigated via fieldwork for the acquisition of empirical data. This process is supported with a literature review on three additional supportive case studies exploring the same phenomena in the different cases.

To better understand the interventions in land administration in conflict and post-conflict contexts, a qualitative research approach (obtaining data via a case study) was applied in Kosovo (Chapter 3). In Rwanda, data collection was executed in three separate fieldwork activities in Eastern Rwanda (Chapter 4). To support the analyses of the data from the main case studies, additional analyses of the same topic is performed in three supportive case studies: Mozambique (Todorovski et al., 2013), Cambodia (Todorovski and van der Molen, 2014) and Timor-Leste (Todorovski et al., 2015c). Data from 
both main and supportive case studies are analysed and discussed with respect to the three characteristics for post-conflict state building. These discussions identified the relation between land administration and state building in post-conflict contexts. In the following section a summary of discussions about the identified relation is presented for each case. Based on the theoretical perspective from section two and guided by the lessons learned for the cases a table of interventions in land administration for postconflict state building is created at the end of the following section.

For the purpose of discussions and analyses of the evidence collected from our cases, correlation analysis is performed in order to derive an analytical generalisation about the phenomenon. Correlation is a technique for investigating the relationship between two continuous variables and measures the strength of the association between those two (UWR, 2015). This is done by using a three-dimensional matrix. The rows of the matrix represent the thirteen elements from the framework for rebuilding a postconflict state in section two (Table 5.1). The columns of the matrix represent the different interventions in land as identified in the following section and summarised in Table 5.2. Together these two tables form the skeleton for the matrix, which is enriched by evidence collected in the field on the main case studies. The results from the case studies together with the matrix will be a fundament for the analytical generalisation about the phenomenon.

\subsection{Lessons learned from the cases}

The structure for presenting the collected evidence for each case will be: (1) background factors about land, conflict and post-conflict contexts; and then (2) specific elaboration of the interventions in land administration with focus on the post-conflict state building using the structure from Table 5.1: (a) institutional weaknesses, (b) economic and social problems and (c) security problems.

\section{Lessons learned from the main case studies}

In the following two sub-sections the summary of the discussions from analyses of the empirical data from the main case studies are presented.

\section{Case study Kosovo}

Background factors of the land, conflict and post-conflict context: Before the conflict in Kosovo, the administration of land became part of discriminatory practices which fuelled ethnic tension dramatically. Having the administration of land as a fuelling factor for the conflict is an important element to acknowledge; it will require a careful approach when the post-conflict agenda is set up. This was definitely visible in the example of Kosovo. During the conflict, one third of the housing stock was destroyed, and property rights 
were severely violated. At the technical level, in many cadastral offices the existing records were purposely taken away and transported to Serbia. Specific land management and land administration issues were included in the peace agreement document (UN, 1999c).

Institutional weaknesses: The legitimacy of the state in the case of Kosovo was fully realised via the intervention of the United Nations Interim Administration Mission in Kosovo - UNMIK (UN, 1999c), with the land sector supported through the involvement of UN-HABITAT. Establishment of a landclaims commission organisation such as the Housing and Property Directorate, Housing and Property Claim Commission and Kosovo Cadastral Agency as governmental entities contributed to the post-conflict government structure. Within the Kosovo Cadastre Support Programme a training programme was developed and employees were trained and educated (Onkalo et al., 2002). In Kosovo, first a specific organisation and implementing programmes were created with a mandate for development of the housing and property rights and land administration, which later led to the development and adoption of the Land Administration Policy (2003) and the Law on Cadastre (UNMIK, 2003). Developments were evident at an institutional and technical level, creating laws and bylaws, organizations, mandates, and building the capacities both in staff and equipment.

Economic and social problems: Addressing land issues in the UNMIK document (UN, 1999c) was a first step of involvement of a specific housing and property rights and land administration in the improvement of the economic and social situation of Kosovo. This assisted the solution of displacement and destroyed properties by providing cadastral products and services. The availability of land dispute resolution mechanisms supported the displaced people in settling the land disputes and reducing the social and security tensions (UNMIK, 2006). An efficient mechanism was put in place to solve the numerous housing and property rights claimed by returning displaced citizens, and this created a good basis for further societal development. Furthermore, the creation of the Kosovo Cadastral Agency and the development of the land policy and the land law resulted in improvement of the land registration and land administration system (Smith, 2002). The development of the land administration function in Kosovo was supported by the implementation programme which contributed to a sustainable development and supported the real property market. The success of the programme suggests that it influenced the economic development and reduced social tensions. Development of land administration, specifically in the recovery of the land records that were removed from Kosovo, contributed to the service provision to all land related sectors and significantly increased the security of land rights. This is also seen as supporting the establishment 
of the land market within the overall economic development of Kosovo (Anderson and Onkalo, 2004).

Security problems: Addressing specific housing and property rights and land administration issues in the UNMIK mission document (UN, 1999c) was the first involvement of specific land issues in support of the security situation. In Kosovo land dispute resolution mechanisms through the mentioned organisations, supported the settlement of the disputes over land and reduced conflict tensions (Todorovski et al., 2015b).

For better illustration of the interventions in land administration in postconflict Kosovo, Table 3.1 in Chapter 3 of this research was created.

\section{Case study Rwanda}

Background factors of the land, conflict and post-conflict context: In the case of Rwanda land issues were considered a major cause used to increase ethnic division leading to violent conflict (Magnarella, 2005). This is an important fact for consideration, because in such a case land requires attention in postconflict state building activities, as was the case in post-conflict Rwanda. The conflict in Rwanda ended with a genocide in which 800,000 people died, and destruction of houses and infrastructure took place (Prunier, 1997). The Arusha peace agreement document for Rwanda paid limited attention to land mainly in regards of displaced population (Bruce, 2007; R. PAD, 1993). This could be a reason for later developments of the land issues in the reconstruction phase of the post-conflict period. Rwanda had more than two and a half million refugees. Displacement had a large impact on the land and its administration (Potel et al., 2015).

In the early stages of the post-conflict period in Rwanda, the political stability was realized with military intervention (Takeuchi, 2011). Taking in the long run the development in the housing, land and property (HLP) and land administration sector contributed to political stability integrated in the broader National Development Strategy. It was found that the developments of a legal framework, the establishment of organizations, and the participation of the citizens in the land sector (Songo, 2014) contributed to the realization of the rule of law in the case of Rwanda.

Institutional weaknesses: In Rwanda it was found that building the legitimacy of the state initially was based on the land sharing policy, allocation of state land, and housing and village settlements (Hilhorst and van Leeuwen, 2000; Huggins, 2009). Establishment of organizations such as land-claim commissions, different Ministries responsible for land, and Rwanda Natural Resources Authority as governmental entities, contributed to the post-conflict government structure. In Rwanda first a land policy was developed, which 
later led to the development and adoption of land laws and appointment of a specific organization with a mandate for enforcement of the law and land policy (Songo, 2014). The Land Tenure Regularisation Programme contributed to building capacities in equipment and technology, and to the training and education of professionals involved in land administration sector (Gillingham and Buckle, 2014).

Economic and social problems: Addressing land issues in the Peace Agreement Document (R. PAD, 1993) in a context of social harmony and national reconciliation was a first step of involvement of HLP and land administration in the improvement of the economic and social situation. This commitment, from the PAD, could be further identified in the actions of local authorities when they supported the acceptance of displaced people at a local level, and assisted in the land sharing and village settlement processes. Where required, sector authorities mediated and advised on the land sharing and distribution of the state land between returnees from different periods. This mediation is seen as a successful land dispute tool, and when this failed the official three level land-claim committees were involved (Potel et al., 2015). Development of the land policy and land law resulted in an improvement of the land registration and land administration system in Rwanda. Development of the land administration was supported by the Land Tenure Regularisation Programme which contributed to sustainable development and supported the real property market. Initial success of the Programme suggests that it influenced an increase of the agricultural productivity, economic development and reduced social tensions. Development of land administration contributed to the service provision to all land-related sectors and significantly increased the security of the land rights (Gillingham and Buckle, 2014). This is also seen as supporting the establishment of the land market within the overall economic development of Rwanda (Todorovski et al., 2015a).

Security problems: The security situation in early post-conflict Rwanda could be described as tense and fragile, with a large military presence (Prunier, 1997; Takeuchi, 2011). In Rwanda, mediation and advice by sector authorities on the land sharing and distribution of state land, supported settling the land disputes and reduced conflict tensions over land significantly. The three level land-claim committees were available as official authorities in Rwanda (Manirakiza, 2014). Addressing land issues for the benefit of displaced people in the PAD (R. PAD, 1993), facilitating land redistribution, land sharing and the village settlement program by the communities members and local authorities, and resolving the land disputes and claims (Potel, 2014) could therefore be identified as elements of the security situation in post-conflict Rwanda. 
Table 4.1, in Chapter 4, illustrates the interventions in HLP and land administration in Rwanda, and how they did fit within the overall post-conflict state building.

From the developments as described and evaluated in this case study it can be derived that in Rwanda the post-conflict context fostered the development of the HLP and land administration and vice-versa these interventions can be seen as facilitators of the post-conflict state building.

\section{Lessons learned from the supportive case studies}

In order to support the results from the analyses of the data from the main case studies, additional analyses of the same topic is performed in three supportive case studies: Mozambique, Cambodia and Timor-Leste. In the following three sub-sections the results from the analyses of the supportive case studies based on literature review are presented in the same structure as the results from the main case studies.

\section{Case study Mozambique}

Background factors of the land, conflict and post-conflict context: The main causes for the 16-year civil war in Mozambique were big political and ideological disagreements. One of the many surrounding factors to the conflict was the way the state dealt with and managed the state land, more specifically the government's village settlements programmes (FAO-LSP, 2004).

The conflict in Mozambique had the characteristics of an intra-state conflict which resulted in approximately 6 million people being displaced; more than half were IDPs. Mozambique had more displaced people than any other country in Africa. Many IDPs went to the cities and stayed there during and after the conflict; many refugees after their return also found shelter in existing towns and cities; an example where displacement fosters urbanization (Todorovski et al., 2013). In the General Peace Agreement land issues were mentioned only in relation to displaced people (PAD, 1992). Land issues were negatively affected by the conflict, and they grew in complexity after the end of the conflict. The situation got more complicated with big lease/concessions given by different governmental actors to national and international companies. It is estimated that in period of two years after the end of the conflict, 40 million hectares of land (more than half of Mozambique 's total area) had been granted in concessions or 'sold' to commercial enterprises. A study was conducted by the Ministry of Agriculture, Ad Hoc Land Commission and USAID to support the development of the Land Policy in the period of 1992-94 (Myers, 1994). However, interventions on the land issues happened later in the early recovery period after the conflict. 
Institutional weaknesses, and economic and social problems: After land was identified as a very important element for the future development of postconflict Mozambique, land issues came very high on the state political agenda. The National Land Policy was developed in 1995. The Land Law was developed in 1996 and came into force in 1997. Regulations for Land Law rural land have been in force from 1998. In 2000 a technical Annex to the Land Law was adopted related to the processes of identifying and recording the rights of local communities and good-faith occupants (Cossa and de Wit, 2009). Nowadays, it is reputed as one of the best legal land frameworks in Southern Africa. The Government's implementation of the Mozambican Land Law has been criticised for the gap between theory and practice (LANDac, 2012). Land administration was identified as an important element in the post-conflict state building process and for the sustainable development of Mozambique. Therefore this state function went through a continuous development (Todorovski et al., 2013).

Developments in land policy, legislation and the establishment of organisations such as Ad Hoc Land Commission and National Directorate of Land and Forests (DNTF) that were dealing with land problems and administration reveal that this contributed to post-conflict institutional weaknesses in Mozambique.

These developments resulted further in an improvement of the land registration and land administration system which increased the security of land rights, provision of products and services, and establishment of real property market. Thus, we can conclude that these interventions in land administration supported agricultural productivity, economic development and reduced the social tensions in the case of Mozambique.

Security problems: The Ad Hoc Land Commissions (formed in 1993) for managing and solving the competitive claims over land in short period of time started to face challenges of multi-layer competitive claims which were dating from colonial times, the post-independence and civil war periods. Because of the volume and seriousness of claims the Ad Hoc Land Commission continued to deal with large scale land-claims and claims that were very complex. Therefore, informal mediation and conciliation processes were most commonly used by the population to resolve disputes. Elders, traditional leaders, neighbourhood heads, district officials and many NGOs provided informal dispute-resolution services (LANDac, 2012). Land-related disputes were also dealt with by the formal court system (district courts, provincial courts and a supreme court). However, procedures are lengthy and costly and the judicial system is also plagued by corruption (AfDB, 2008). It is believed that the mediation and consultation, and the formal court system reduced the conflicts over land and properties. 


\section{Case study Cambodia}

Background factors of the land, conflict and post-conflict context: Ideological misunderstanding and ethnic divisions could be identified as causes of the protracted civil war in Cambodia which resulted in the death of more than two million people, the majority of whom were from the cities. This conflict, which contains characteristics of intra-state, inter-state and one-sided violence, produced several million IDP's. All citizens of the bigger cities, including Phnom Penh, but also people from the rural areas were constantly displaced during the Khmer Rouge era (1975-79). Private property was abolished, and for the purposes of creating an 'ideal agrarian society' state infrastructure together with all state documentations and archives was destroyed (Robben, 2010). Displacement and creation of the agrarian society increased the land dimension of the conflict in the case of Cambodia.

Cambodia is considered an agrarian state where $80 \%$ of the population is involved in agriculture (Törhönen, 2001). Effects of the conflict had a big impact on the land administration in Cambodia, where all land records, maps and documentation were lost as well as most land professionals and people educated in land were eliminated during the conflict.

Institutional weaknesses and economic and social problems: Private ownership was abolished during the Khmer Rouge era. But even with its reintroduction after 1989, Cambodia faced technical, financial, legal and organisational obstacles in performing this very important state function. In the mid-90s developing partners in the land sector, the Governments of Germany and Finland started to provide assistance and support, and consequently things started to improve. The period from 1995 until 2001 is marked by many study projects, fact-finding missions and pilot projects in some of Cambodia's provinces. This resulted in the development of the Land Policy and new Land Law in 2001, followed by a multi-donor Land Management and Administration Project (LMAP) which started in 2002. LMAP finished in 2009 with the continuation as the second phase named Land Administration Sub Sector Program - LASSP (Anttonen, 2010). Achievements of these projects were possible with involvement of multi-disciplinary stakeholders and they went in alignment with the Government Statement on Land Policy from 2001 in achievement of the national goals: economic development, poverty reduction and good governance. Effects from the conflict, prolonged rebuilding of the state and establishment of all postconflict state processes (Joseph, 2013). This was also the case with the improvements in the land administration sector. Developments may be later but evident in the land sector of Cambodia and this supports at least two characteristics of the post-conflict environment, they contribute towards strengthening of the institutions, and towards economic and social development (Todorovski and van der Molen, 2014). 
Security situation: Land disputes and conflicts over properties occurred in Cambodia for a longer period after the end of the conflict. Conflicts over land have increased in Cambodia because of the ambiguity of land rights. One of the typical land disputes involved unregistered lands that become the object of economic land concessions even though people live on the lands. Most frequent conflicts over land and properties were conflicts between the neighbours about their parcel boundaries and conflicts between villages. Cadastral commissions, the National Authority for Land Dispute Resolution (NALDR), and the courts were the formal institutions that played an important role in dispute settlement. The functions of a commission were defined by the 'Organization and functioning manual' (2002). Although the cadastral commission system has played a role in the facilitation of land disputes, it has not been able to keep up with the increasing number of land disputes. The National Cadastral Commission report (2008) pointed out that five years after the establishment of the commission, only $1 / 3$ of land-claims have been solved (Sekiguchi and Hatsukano, 2013). Therefore we conclude that resolution of land disputes and claims is questionable as regards overall security in Cambodia.

\section{Case study Timor-Leste}

Background factors of the land, conflict and post-conflict context: The history of Timor-Leste in the period of 1974-1999 is marked with violations of human rights such as: self-determination, killing and disappearance, forced displacement and famine, detention and torture, violation of the laws of war, political trials, sexual violence, violations of the rights of children, and violations of economic and social rights (CAVR, 2005).

The land administration in Timor-Leste was heavily influenced by the colonial and conflict characteristics. The largest impacts on the land administration issues were: displacement, illegal occupation, destruction of infrastructure and houses, land records burned and destroyed, and land professionals fleeing the country (Fitzpatrick, 2002). The rule of law being essential to a state emerging from a conflict, we found that developments of the legal land framework, the establishment of organisations dealing with administration of land, and the participation of communities and the citizens in the land sector (USAID, 2012), contributed to the realisation of the rule of law in the case of Timor-Leste.

Institutional weaknesses: Legitimacy of the state initially was supported by involvement of the UN mission in Timor-Leste UNITAET and the international community; the land sector was supported by UN-HABITAT. The post-conflict governmental structure was supported by the creation and performance of the National Directorate for Land, Property and Cadastral Services (DNTPSC) an organisation responsible for land registration and administration, and the 
registration of disputed properties. DNTPSC, with the support of UN and international donors, significantly improved the legal framework and operational procedures. Training and education of the staff of DNTPSC was and still is supported by capacity building projects funded by international donors. Post-conflict land administration had a positive role in strengthening the institutional weaknesses of Timor-Leste (Todorovski et al., 2015c).

Economic and social problems: Addressing land issues in the Agreement Document (AD, 1999) was a first step of involvement of specific land disputes mechanisms and land administration in the improvement of the economic and social situation. DNTPSC assisted with displacement and destroyed properties by providing cadastral products and services - when they became available. The project Strengthening Property Rights in Timor-Leste supported by USAID (USAID, 2012) and the National Recovery Strategy had a successful implementation, which to a high degree put an end to the long and difficult problems of the displaced people (Van der Auweraert, 2012). It is believed that the project and the strategy had a beneficial impact on social life in support of the overall difficult economic situation in Timor-Leste. Development of land administration, specifically the creation of the land records that had been destroyed and were unavailable, contributed to the service provision to all land-related sectors and significantly increased the security of the land rights. This was also seen as a support of the establishment of the land market within the overall economic development. As discussed here, interventions in land administration contributed to the improvement of the economic and social situation of Timor-Leste.

Security situation: After the conflict ended in 1999, the peace-keeping process in Timor-Leste was realized with involvement of UNTAET and UN security forces. However, their presence was not enough to stop the escalations of the social unrest into the crisis in 2006. With the establishment of the second UN mission UNMIT, where international police forces were included, the overall security situation was on a higher and acceptable level. HLP and land administration issues that contributed to the security situation in other post-conflict cases were creation and availability of functional land dispute resolution mechanisms. With the Law No. 1/2003 this duty for the case of Timor-Leste was briefly given to the DNTPSC, but further legal legislation, operations and procedures were not developed at that time. It was identified that within the registration process there was a possibility to map the disputed parcels. These maps were publicly displayed at easily accessible points in the communities. It is believed that this stopped the continuation of the illegal land and property transactions; with this conflicts over disputed properties were significantly reduced (Todorovski et al., 2015c). From the video statement of a village chief from Timor-Leste we can derive that registration of land in the land administration system and 
availability of lease agreements and land records, resulted in preventing conflicts over land. In the past these conflicts over land were a regular practice but nowadays, with availability of the lease agreements, this is reduced especially in inheritance cases (Mokokoane, 2014). These developments to some degree supported to the security situation of postconflict Timor-Leste.

\section{Interventions in land administration for post-conflict state building}

The theoretical perspective, in section two, identified some aspects as regards to land administration in post-conflict contexts that need attention in such contexts. Based on the identified aspects from literature together with analysed and discussed data from our case studies, we derive various interventions in land administration for post-conflict state building, that were found in at least one case, see Table 5.2. The interventions in Table 5.2 are presented in no apparent order.

Table 5.2: Interventions in land administration for post-conflict state building

\begin{tabular}{|c|c|c|c|c|c|}
\hline $\begin{array}{l}\text { Interventions in land administration } \\
\text { for post-conflict state building }\end{array}$ & $\begin{array}{l}\text { O } \\
\text { O } \\
\text { O } \\
\text { ํ }\end{array}$ & 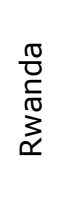 & 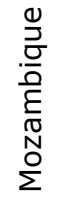 & 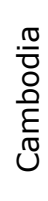 & 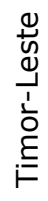 \\
\hline National Land Policy & $\sqrt{ }$ & $\sqrt{ }$ & $\sqrt{ }$ & $\sqrt{ }$ & $\sqrt{ }$ \\
\hline Cadastre / Land Law & $\sqrt{ }$ & $\sqrt{ }$ & $\sqrt{ }$ & $\sqrt{ }$ & $\sqrt{ }$ \\
\hline Land administration organisations & $\sqrt{ }$ & $\sqrt{ }$ & $\sqrt{ }$ & $\sqrt{ }$ & $\sqrt{ }$ \\
\hline Land-claims commissions & $\sqrt{ }$ & $\sqrt{ }$ & $\sqrt{ }$ & $\sqrt{ }$ & $\sqrt{ }$ \\
\hline Implementation program / project & $\sqrt{ }$ & $\sqrt{ }$ & & $\sqrt{ }$ & $\sqrt{ }$ \\
\hline $\begin{array}{l}\text { Ad hoc land policies: land sharing, } \\
\text { state land for housing and village } \\
\text { settlements }\end{array}$ & & $\sqrt{ }$ & & & \\
\hline $\begin{array}{l}\text { Specific land management / } \\
\text { administration issues in PAD }\end{array}$ & $\sqrt{ }$ & $\sqrt{ }$ & & & $\sqrt{ }$ \\
\hline Land registration improved/created & $\sqrt{ }$ & $\sqrt{ }$ & $\sqrt{ }$ & $\sqrt{ }$ & $\sqrt{ }$ \\
\hline Recover/create land records & $\sqrt{ }$ & $\sqrt{ }$ & $\sqrt{ }$ & $\sqrt{ }$ & $\sqrt{ }$ \\
\hline $\begin{array}{l}\text { Train/educate land professionals - } \\
\text { capacity building }\end{array}$ & $\sqrt{ }$ & $\sqrt{ }$ & $\sqrt{ }$ & $\sqrt{ }$ & $\sqrt{ }$ \\
\hline $\begin{array}{l}\text { Cadastre products and services for } \\
\text { displaced population and destroyed } \\
\text { infrastructure \& houses }\end{array}$ & $\sqrt{ }$ & & & & \\
\hline $\begin{array}{l}\text { Land dispute mechanisms (by } \\
\text { mediation or adjudication) }\end{array}$ & $\sqrt{ }$ & $\sqrt{ }$ & $\sqrt{ }$ & & $\sqrt{ }$ \\
\hline
\end{tabular}




\subsection{Discussions and analyses}

In this section firstly, some general findings on land, conflict and post-conflict contexts are presented; secondly, correlating analysis is performed represented in a three dimensional matrix; and finally this chapter shows how the first two elements strengthen the analytical generalisation at the end of this section.

\section{General findings on land, conflict and post-conflict contexts}

Our cases showed that in some cases land was a major cause or it was one of many fuelling factors that influence the eruption of armed conflict. Therefore, land issues required specific attention during the state building in postconflict contexts. This confirms the recognition that all conflicts have a land dimension. From the lessons learned from the cases it was beneficial that specific interventions in land administration and land-related issues were included in the peace agreement documents integrated in the UN operations. Our findings showed that if this was not the case, development of the land segment occurred later, resulting in complicating and slowing down the postconflict state building. Where applicable it was beneficial to quickly adopt ad hoc land policies, which strengthened the legitimacy of the state and supported the political stability. Developments in the land sectors with reference to land legislation, organisations with mandate for its enforcement, and participation by citizen and authorities involved, contributed to the rule of law in the specific post-conflict states.

\section{Correlating analysis}

In this sub-section correlation analysis is performed using a three dimensional matrix. In the matrix, the theoretical propositions are characteristics for rebuilding post-conflict states (Table 5.1) and the interventions in land administration for post-conflict state building (Table 5.2). The matrix is empowered with evidence collected in the field on the main case studies, where these evidences will be analysed. Each position is filled when the specific intervention in the specific case contributed to the specific element of state building, as given in Matrix 5.1. As an example of how the actual filling in of the positions in the matrix will take place a description for one activity will be demonstrated as follows:

Intervention of 'national land policy' (the Policy): Intervention of the Policy did not have identical developments in both Kosovo and Rwanda but it had a lot of similarities. As shown in our main cases, it supported the characteristic 'legitimacy of the state/political leaders'. The Policy was created by the authorities to fulfil the needs of all stakeholders dealing with land from state's side, local authorities and citizen's participation - this strengthened the relationship between state and societal groups. Development of the Policy in 
such a way, integrated in a broader National Development Strategy, contributed to strengthening the weak 'political system' and 'governmental structure' as well. The Policy contained guidelines for a further 'legal framework' development, and directions for the creation of authorities and mandates to organisations to enforce the law and policy. The actual development of the Policy supported 'building capacities' of the state and it included parts for further activities in this regard. As an element that required appropriate attention in post-conflict context the 'displaced population', this issue had adequate attention in the Policy. The Policy had reference to 'destroyed houses and infrastructure' but it did not directly support this element - that's why this position is empty in our matrix. During the development of the Policy 'participation of the international community, national and local authorities' and 'participation of citizens' was required and this had prospects to continue in the future as well. Since the Policy did not directly support the 'low economic activity' and did not contain precise references in our main cases to 'lost/destroyed state records' it has empty positions in our matrix. Our cases show that the Policy had attention and contributed to the process of 'peace building and reconciliation' and in regard of 'conflicts over land'. 


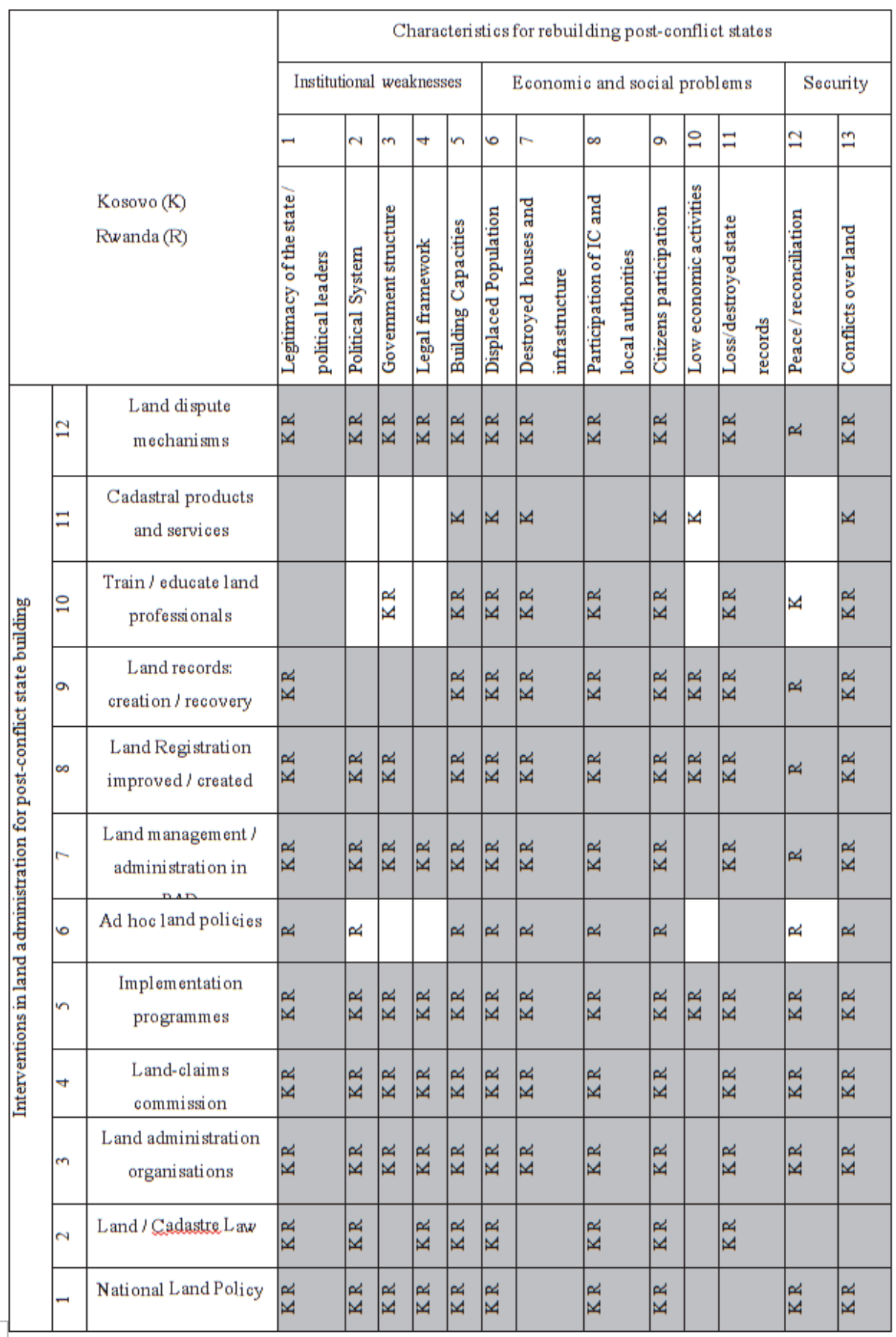

Matrix 5.1: Interventions in land administrationthat facilitate post-conflict state building 
Rows and columns are shaded to highlight the outcomes from the correlating analyses in the matrix.

Observing Matrix 5.1, we can see that nine out of twelve interventions are ticked for more than two thirds of the positions. The columns of 'ad hoc land policies' and 'cadastral products and service' have lowest number of ticked positions - interventions that occurred in each case separately. Nine interventions that have the highest number of ticked positions appear in the following order: 'implementation programme or project', 'land administration organisations', 'land-claims organisations', 'land management/administration in PAD', 'land registration' 'land dispute mechanisms' followed by 'national land policy' 'creation/recovery of land records' and 'land/cadastre law'.

Further, observing the Matrix 5.1, we can also see that eight out of thirteen elements of the characteristics are ticked for more than two thirds of the positions. Therefore we derive that the characteristics: 'displacement', citizen participation', 'building capacities of the state', 'participation of IC and local authorities', 'conflicts over land', 'legitimacy of the state/ political leaders', 'lost/destroyed state records' and 'destroyed houses and infrastructure' benefit most from the interventions in land administration. The characteristics with ticked positions in more than a half of the positions are: 'political system', 'governmental structure', 'legal framework' and 'peace and reconciliation'. Only the characteristic 'low economic activities' is ticked in about one third of the positions.

\section{Analytical generalisation}

As regards the first set of characteristics, institutional weaknesses, we come to the following findings. Our cases have shown that development of a National Land Policy in post-conflict contexts resulted in a benefit to all related users, when it was developed within a broader National Development Strategy, jointly developed and accepted by all related stakeholders. Land Policy contained clear directions about development of the Land Law and appointment of specific organisations with a mandate for enforcement of the law and the policy. In all our cases creation of specific organisation such as land administration organisations and land-claims commissions supported the governmental structure and strengthened the weak post-conflict political system. Building capacity was required and implemented as regards: legal framework, creation of organisations, education and training of land professionals and equipment. Building capacities in all cases were supported with assistance from international actors or development partners. Our cases have shown that the mentioned land related activities are most effective and efficient when developed with international assistance and through implementation programmes. Interventions in land administration as 
described in this part contributed to improvement in the low legitimacy of the political leaders and legitimacy of the state as well. For one of our cases, Rwanda, findings showed that building the legitimacy of the state initially was based on the ad hoc land sharing policy, allocation of state land, and housing and village settlements.

From the second set of characteristics, economic and social problems, we derive the following. Addressing the specific land management/administration intervention within the peace agreement documents of the three cases (Kosovo, Rwanda and Timor-Leste), and addressing land issues as regards displaced persons in all cases, was a first step of involvement of land and its administration in the improvement of the economic and social situation in post-conflict contexts. Creation of specific land-claim commissions and land administration organisations supported the population and specifically the displaced people in settling the land disputes and reducing the social and security tensions. The aim of land administration organisations was the creation or improvement of the land registration and land administration system. Our cases showed that this was successfully realized, supported by implementation programmes or projects, which further contributed to a sustainable development and supported the real property market. The success of the implementation programmes and projects shows that it influenced the economic development and reduced social tensions. Development of land administration, specifically in the creation of land records in four cases or recovery of the land records (as in the case of Kosovo), contributed to the service provision to all land-related sectors and significantly increased the security of land rights. This supported the establishment of the land market and improved the overall economic development. When land records become available, provision of land products and services assisted the requirements of displacement and destroyed properties.

The security situation in post-conflict contexts by default is tense and fragile, with a large military presence. Addressing specific land management/ administration (in three cases) and land related issues in regards of displaced population in the peace agreement document, as was shown in all our cases, to some degree contributed to address the difficult security situation. Landclaims mechanisms (using mediation or adjudication methods) were adequately developed in four of our cases, but not in Cambodia. These mechanisms are seen as instruments that supported the settlement of the disputes over land and reduced conflict tensions. 


\subsection{Conclusions}

This chapter was aiming at giving an answer to the research question: how interventions in land administration facilitate post-conflict state building? This was done initially by identifying thirteen elements in the framework for rebuilding post-conflict states based on a theoretical perspective. Lessons learned from the cases were based on empirical data from the main cases and supported by the findings from the supportive case studies in a structure of the three characteristics of Ball (2001). Accordingly, interventions in land administration for post-conflict state building were acknowledged. Correlation analyses enriched the analytical generalisation in discussions on how interventions in land administration are undertaken and how those facilitate post-conflict state building.

From the analyses of the finding we conclude that developments in the land sector with interventions in housing and property rights and land administration are identified as elements that contributed to strengthening the institutional weaknesses - the first characteristic. Interventions in land administration and housing and property rights which contributed to the development of land associated sectors lead us to identify them as elements that contributed to improving the economic and social problems - the second characteristic. We identified that interventions in disputes over land and properties and land administration supported settlement of these disputes, reduced conflict tensions and to some degree improved the security problems in post-conflict contexts - the third characteristic for rebuilding a post-conflict state. All of the above leads to the conclusion that the identified interventions in land administration facilitate post-conflict state building. 
Chapter 6

Conclusions and Recommendations 


\subsection{Introduction}

The recognition of the role of land and its administration in post-conflict contexts is attracting the attention of international practice, politics and scientific debates. Chapter one of this research started by reviewing the existing literature on the three interrelated topics: conflict and post conflict contexts, land and its administration in post-conflict contexts and postconflict state building. The following gap in the knowledge was discovered: the relationship between land administration and post-conflict state building was not appropriately addressed in the literature. Chapter two was devoted to the examination of characteristics of conflict and post-conflict contexts in relation to land. Initially land and other resources in conflict and post-conflict contexts were explored in order to increase the understanding of this subject. With the recognition of the important role that land played in such contexts, examination continued in discovering how land was managed and administered in conflict and post-conflict contexts. As stated in the propositions in chapter one, the findings from chapter two set the base for the case studies; examination and collection of empirical data for our main cases of Kosovo and Rwanda. Chapter three explored the conflict and postconflict land administration in the case of Kosovo, where the relationship between land administration and post-conflict state building emerged. Furthermore, characteristics of post-conflict state building with focus on land issues were explored more in depth through the case of Rwanda in chapter four. Chapter five integrated the collected evidence from the main case studies and supported this with findings from three supportive case studies: Mozambique, Cambodia and Timor-Leste, in which the same phenomenon was investigated based on the literature review. The collected evidence was integrated in a three-dimensional matrix which supported the analytical generalisation and discussions for increasing the understanding of the relationship between interventions in land administration and post-conflict state building.

This chapter synthesizes the findings from chapter two to chapter five based on the four research sub-objectives proposed at the beginning. These objectives were:

- Examine the characteristics of conflict and post-conflict contexts in relation to land;

- Explore and identify specific interventions in land administration for postconflict contexts;

- Recognize the characteristics of post-conflict state building with focus on land issues; 
and

- Assess which interventions in land administration in post-conflict contexts took place and how those interventions could be recognised as a facilitator of post-conflict state building.

The following section 6.2 provides discussion of the main findings of each specific objective and section 6.3 discusses the implication of these results for knowledge and literature, policy formulation and implementation, and benefits of the results for the practitioners. Finally, section 6.4 provides recommendations for future research.

\subsection{Main conclusions from the research}

This section summarises the main findings based on each of the research objectives listed above. Sub-objective one is addressed in chapter two. Subobjectives two and three are observed in both chapter three and chapter four. In chapter three the leading case is the case of Kosovo and this case is investigated to achieve the sub-objective two, and in chapter four the leading case is the case of Rwanda and this chapter reflects to sub-objective three. In addition sub-objective four is addressed in chapter five.

\section{i Examine the characteristics of conflict and post-conflict contexts in relation to land}

The most serious concerns in present-day conflicts are: the death of people, the destruction of houses and infrastructure and the displacement of population. This research confirmed that natural and other resources can act as a motive for the conflicts and can finances them; it was also confirmed that climate change has an impact on conflicts as well. Compared to the conflicts of the last century, the number of people killed in conflicts nowadays has decreased but more civilians die in conflicts instead of military personnel. This research revealed that the destruction and the displacement had the greatest effect on land and its administration.

It was shown that in some cases land was a major cause or it was one of the many factors that influenced the eruption of an armed conflict. Other related types of conflicts identified here were secondary conflicts and land conflicts. This research confirmed the recognition that land was identified as a critical gap in the international response capacities and that all conflicts have a land dimension. It revealed that land issues required specific attention during the state building in post-conflict contexts. From the lessons learned from the researched cases it was shown that it was beneficial when land-related issues and specific land management and administration were included in the peace agreement documents integrated in the UN operations. Where this was not 
the case, development of the land segment occurred later, resulting in the complicating and slowing down of the post-conflict state building.

At the end of a conflict displaced people return to their places of origin in large numbers. This research has shown that together with this land-related issues like burned or destroyed houses and properties illegally occupied by secondary occupants are critical in the post-conflict contexts. The normative framework for addressing housing, land and property rights in context of displaced persons is summarised in COHRE (2007), known as the 'Pinheiro Principles'. In this research, land and property disputes and claims in postconflict period were recognised as threatening issues. When left unaddressed, they were a cause for new violent situations and secondary conflicts. The cases researched in this research confirmed that land administration systems suffered mostly from the loss of land records and loss of land professionals. Having acknowledged the goal of land administration and its potential, land administration was deemed as an appropriate instrument for the implementation of the national land policy, and this should be embedded in a wider development plan of the state emerging from conflict.

\section{ii. Explore and identify specific interventions in land administration for post-conflict contexts}

To reach the second objective of this research, a fieldwork for data collection was executed in order to better understand the intervention in land administration in the period before and during the conflict and in the postconflict period in the case of Kosovo. This research discovered that prior to the conflict administration of land became part of discriminatory practises which fuelled ethnic tension dramatically. During the conflict, apart from the most regrettable casualties, major parts of the housing stock were destroyed and property rights were severely violated. At a technical level, in many cadastral offices the existing records were purposely taken away and transported to Belgrade. It reveals that at the end of the conflict, the land question was adequately included in the peace agreements, which led to involvement in land matters by UNMIK and the international community, in particular UN-HABITAT. This has initiated the development and implementation of the Kosovo Cadastre Support Programme. During the phases of post-conflict development, of the emergency, the early recovery and the reconstruction phase, the international community, the UNMIK administration and local actors developed a system of housing and property rights and related land administration function. It was shown that developments were evident at an institutional and technical level, creating laws and bylaws, organisations, mandates, and offering building up the capacities both in staff and equipment. In addition, an efficient mechanism was put in place to solve the numerous housing and property rights claimed 
by returning displaced citizens. It reveals that all this has created a good basis for further societal development.

All these developments revealed that housing and property rights and the related land administration functions might be seen as contributors to postconflict state building. Therefore, we observed the interventions in housing and property rights and land administration from the perspective of postconflict society's theory. Contributions from interventions in housing and property rights and land administration can be grouped under the three characteristics for rebuilding post-conflict states: improvement of institutional weaknesses, tackling social and economic problems, and enhancing the security situation. It was discovered that strengthening of the institutional weaknesses in the land sector (implementation programme, land administration and land claim organisations, land law, land policy and building the capacities) were identified as elements that contributed to strengthening of the institutional weaknesses of post-conflict Kosovo. In addition it was shown that interventions in housing and property rights and land administration, which contributed to the development of land associated sectors, were proven as elements that contributed to improving the social and economic problems of the post-conflict Kosovo. Finally, including the specific land administration and land management issues in the peace agreement and land dispute resolution the organisations supported the settlement of the disputes over land and reduced conflict tensions. This research verified that interventions in housing and property rights and land administration were identified as elements that supported reducing the security problems in post-conflict Kosovo. These findings led to the conclusion that indeed the interventions in land administration made a positive contribution in addressing each of the three characteristics of rebuilding post-conflict states.

\section{iii. Recognize the characteristics of post-conflict state building with focus on land issues}

Chapter four of this research was dedicated to identifying the characteristics of war-torn societies from theory and to relate that to housing land and property issues and land administration in post-conflict context. For this we used the collected evidence from the case of Rwanda.

One of the characteristics of post-conflict state building are institutional weaknesses, which was initially addressed by applying specific land policies. Land policies have significant influence on the population and they contribute to creating legitimacy for the post-conflict state. It revealed that land policies led to the development of land laws and appointed organisations for enforcement of the policies and the laws. This research showed that land administration organisations and land claim commissions strengthened the 
governmental structure. Implementation of legal frameworks was most successful via appropriate implementation programs, as shown in the good practice in the case of Rwanda.

Another characteristic of post-conflict state-building activities are ongoing social and economic problems. These problems were tackled with the promotion of peace, social harmony and reconciliation. Land-related issues, specifically in relation to a displaced population, were addressed in the same manner. Mediation and advice in allocation of land to returnees, or land policies supported by local authorities, and official land claim commissions for settling land disputes, as it was shown via the case of Rwanda supported the social situation. Improvement of the service provision, within the land administration sector, via appropriate implementation programs increased the security in land rights. A supportive implementation program in land administration strengthened the development of a land market and the overall economic situation of a post-conflict state.

The security situation is always problematic in a post-conflict context. Land dispute resolution institutions were accepted and developed as contributors to overall security in a post-conflict Rwanda. Including land dispute resolution institutions in the peace agreement document and in the UN operational guides showed that this can speed up the development of such institutions. Availability of mediation methods or official land dispute resolution institutions was recognized as an element that supported the security situation after the conflict.

This chapter identified the characteristics for rebuilding post-conflict states and related them with housing and property rights and land administration. The conclusions from this chapter are that land related issues and land administration indeed play a substantial role in post-conflict state building in the case of Rwanda.

\section{iv. Assess which interventions in land administration in post- conflict contexts took place and how those interventions could be recognised as facilitator of post-conflict state building}

The fifth chapter of this research aimed at increasing the understanding of the relation of interventions in land administration in conflict and post-conflict contexts with post-conflict state building. Thirteen elements, grouped under the three main characteristics, were identified in the framework for rebuilding post-conflict states taken from a theoretical perspective. Lessons learned from the cases were based on empirical data from the main cases and supported by the findings from the supportive case studies. Accordingly, the table containing interventions in land administration for post-conflict state building was derived. Correlation analyses enriched the analytical 
generalisation in discussions on how interventions in land administration facilitate post-conflict state building.

In regard of institutional weaknesses, this research shows that development of a National Land Policy in post-conflict contexts resulted in a benefit to all related users. This was most efficient when it was developed within a broader National Development Strategy jointly created and accepted by all related stakeholders. The land policy needs to contain clear directions about the development of the land law and appointment of specific organisations with a mandate for enforcement of the law and the policy. In all researched cases the creation of specific organisations, such as land administration organisations and land-claims commissions, revealed that this supported the governmental structure and strengthened the weak post-conflict political system. In addition, capacity building was required and implemented in relation to the legal framework, the creation of organisations, the education and training of land professionals and equipment. Building capacities in all cases were supported by the assistance from international actors or development partners. Findings from this research have shown that the mentioned land-related activities are most effective and efficient when developed with international assistance and through implementation programmes. Interventions in land administration as discussed in the final analyses, contributed to the improvement in the low legitimacy of the political leaders and legitimacy of the state as well. For one of our cases, Rwanda, findings showed that building the legitimacy of the state initially was based on the ad hoc land sharing policy, allocation of state land, and housing and village settlements.

In regard to economic and social problems, this research concluded the following. Addressing the specific land management / administration intervention in the peace agreement documents in three researched cases and addressing land issues as regards displaced persons in all cases was a first step of involvement of land and its administration in the improvement of the economic and social situation in post-conflict contexts. In addition, the creation of specific land-claim commissions and land administration organisations supported the population and specifically the displaced people in settling the land disputes and reduced the social and security tensions. The aim of land administration organisations is the creation or improvement of the land registration and land administration system. Our cases showed that this was successfully realized, supported by implementation programmes or projects, which further contributed to a sustainable development and supported the real estate market. The success of the implementation programmes and projects, as was a case in the main case studies, reveals that it influenced the economic development and reduced social tensions. Development of land administration, specifically in the creation of land 
records in four cases or recovery of the land records (as in the case of Kosovo), contributed to the service provision to all land-related sectors and significantly increased the security of land rights. This supported the establishment of the land market and improved the overall economic development. This research showed that when land records become available, provision of land products and services assisted the requirements in case of displacement and destroyed properties.

The security situation in post-conflict contexts by default is tense and fragile, with a large military presence. Addressing specific land management/ administration (in three cases) and land related issues in regards of displaced population in the peace agreement document, as was shown in all five cases of this research, to some degree contributed to address the difficult security situation. Land dispute and claim mechanisms (using mediation or adjudication methods) were adequately developed in each of our cases. In addition, this research revealed that these mechanisms are seen as instruments that supported the settlement of the disputes over land and reduced conflict tensions.

The main findings from this research presented here lead to the conclusion that the main research objective was achieved. Namely, the interventions in land administration that took place in post-conflict contexts were identified and it was elaborated how those interventions facilitate post-conflict state building.

\subsection{Implications of the results.}

This section discusses the implication of the results for their contribution in general and in addition specifically in regard of 1) knowledge and literature, 2 ) policy formulation and implementation and 3) the practitioners.

General implication of the results from this study for all is that the identified interventions for post-conflict state building (in Chapter 5) coincide with interventions that are an integral part of the literature on contemporary land administration and successful development programs in these field. Our list of interventions additionally contains creation and availability of land dispute mechanisms, mainly because land disputes and conflicts over properties are more present in post-conflict contexts than in times of peace. Since disputes and conflicts over land are present almost in all societies globally, the ways that those were addressed and elaborated in the case studies of this research, would be beneficial and could be integrated in other wellperforming land administration systems as well. 


\section{i. knowledge and literature}

As discussed in the chapters of this research, land and its administration are increasingly recognised as important elements, in conflict and in post-conflict contexts in literature, but also in international community reports and policy documents, and in practitioners' reports. However, there is limited literature on land administration within post-conflict state building. This research adds the issues of interventions in land administration for post-conflict state building to the land administration literature, literature on peace and conflict, and post-conflict state building literature. The results from this research enrich the understanding of land administration as a facilitator of post-conflict state building.

Literature: EU-UN (2012), Unruh and Williams (2013b) and Takeuchi (2014), revealed research on land and conflict or land and property for peace building. This research tackled the gap in the knowledge and provided new literature contributing to two aspects. In regard of extending the knowledge for land professionals engaged in rebuilding post-conflict societies, the case studies showed that too few land professionals with relevant knowledge in land administration and related issued are engaged in post-conflict contexts. This research and its findings provide a solid base for increasing the knowledge body for the academia involved in this segment and for the land professionals in this regard. In addition, it enhances the knowledge about the post-conflict state building process by identifying which interventions in land administration can be applied and how they could support this process. This provides new literature for researchers and professionals in the fields of peace and conflict studies and post-conflict state building studies.

\section{ii. policy formulation and implementation}

The identified need that land issues should be on the agenda of the international community and included in the negotiations for the peace agreement or National Land Policy of the states emerging from conflict was acknowledged once again in this research.

Policies and legislation lay the foundation for state building: the process of their formulation and implementation is closely related and strengthens the state building process. Our case studies showed that this is of particularly importance in post-conflict contexts. In regard of developing a national land policy, the policy should be developed as an integral part of the broader National Development Strategy. It is recognised that the rule of law is critical to states emerging from a conflict on their way towards stability and longlasting peace. It is important that the rule of law is not only provided for in the law but is also practiced by the officials of the state, allows participation of the citizens and is enforced by the courts. Adaptations of the land policy led to development of land laws and to the establishment of organisations 
that have a mandate for their enforcement. Our cases showed that development of the land policy in earlier stages of post-conflict, as soon as the basic conditions for this are met, would bring results and benefits for all sooner.

\section{iii. the practitioners}

Land administration and post-conflict state building are recognised as multidisciplinary topics involving scholars and professionals from many fields. Therefore, it is our belief that results and findings from this research would be beneficial for multiple practitioners engaged in fields related to land administration in post-conflict contexts. Specific benefits and recommendations would be: 1 ) the mentioning of land issues and specifically land management and land administration in peace agreement documents, as was proved a good practice in the findings from our case studies and 2) the enforcement of land policies and land law, which were proven to have the greatest benefit when supported with implementation programmes or projects at scale for their implementation.

\subsection{Recommendations for future research}

This research provided empirical data to fill the gap in the knowledge, where a positive relationship between land administration and post-conflict state building was recognised. However, recommendations for future research could broaden the potential of land administration as a whole or some of its components supporting post-conflict state building.

Firstly, availability of land dispute administration and resolution institutions are generally accepted as contributors to the overall security in a postconflict situation. Absence of such institutions could result in a small-scale land conflict with a threat that they grow bigger and finally evolve into violent conflicts. Thus, future research could focus on development and testing in real-life alternative and fit-for-purpose land tools which would be more efficient in administration and resolution of land and property disputes in other post-conflict cases or contexts.

Secondly, this research was based on two main case studies and three supportive case studies, where, based on the case study selection criteria given in the first chapter, the case studies were entire states. Other conflict and post-conflict cases (for example: Colombia, Sudan, Ukraine and several states in Middle East) are showing that conflict sometimes affects only parts of these particular states. Therefore, the recommendation for future research is to investigate the same phenomenon under investigation here in such types of post-conflict contexts. 
Thirdly, challenges in regard of displacement of population, as an effect of violent conflicts, are becoming alarming issues for the countries in conflict, transit countries and specifically for the final destination countries. Further research that would investigate housing and property rights and land administration and specific needs of displaced population, regarding circumstances and corridors where they migrate in relation to land is recommended. 


\section{Bibliography}

AD, (1999). Agreement Between the Republic of Indonesia and the Portuguese Republic on the Question of East Timor. New York, USA.: United Nations.

AfDB, (2008). Mozambique: Private Sector Country Profile.: African Developement Bank.

Alden Wily, L., (2009). Tackling land tenure in the emergency to develop transition in post-conflict states: From restitution to reform. In S. Pantuliano (Ed.), Uncharted Territory: Land, conflict and humanitarian actions (pp. 27-50). Warwickshie, UK: Overseas Developement Institute.

Ammitzbøll, K. and Blair, H., (2011). First Steps in Post-Conflict StateBuilding: Establishing Critical Functions and Setting Priorities. In W. E. Feichtinger, E. M. Felberbauer and E. A. Schmidl (Eds.), International Crisis Management: Squaring the Circle. Vienna and Geneva: National Defence Academy and Austrian Ministry of Defence and Sports in co-operation with Geneva Centre for Security Policy.

Anderson, B. and Onkalo, P., (2004). Towards sustainable land administration in Kosovo: final report Kosovo cadastre support programme $I$ (pp. 113). Pristina, Kosovo.

Anten, L., (2009) Strengthening Governance in Post-Conflict Fragile States: Issues paper. the Hague, the Netherlands: Netherlands Institute of International Relations, 'Clingendael', Conflict Research Unit.

Anten, L., (2010) Strengthening governance in a post-conflict district of the Democratic Republic of Congo: a study of Ituri. the Hague, the Netherlands: Netherlands Institute of International Relations , 'Clingendael', Conflict Research Unit.

Anttonen, J. J., (2006). Can a Successful Modern Cadastre Be Developed in South-East Asian Developing Countries? - South-East Asian Experience with the Focus on Cambodia. Paper presented at the XXIII FIG Congress, Shaping the Change, Munchen, Germany.

Anttonen, J. J., (2010). Successful Capacity Building of the Cambodian Land Administration: Finnish Technical Assistance Combined with the Local Khmer Expertise, Traditions and Culture. Paper presented at the FIG Congress 2010, Sydney, Australia,.

Augustinus, C. and Barry, M. B., (2006). Land management strategy formulation in post-conflict societies. Survey Review, 38(302), 668681.

Ball, N., (2001). The Challenge of Rebuilding War-Torn Societies. In A. Croker, Hampson, F. O. and Aall, P (Ed.), Turbulent Peace (pp. 719736). Washington D.C., USA: United States Institute of Peace.

Barnett, J., (2001). The Meaning of Environmental Security: Ecological Politics and Policy in the New Security Era: Zed Books, London.

Batson, E. D., (2008). Registering the human terrain: $A$ valuation of cadastre. Washinton D. C. USA: National defence intelligence college press.

Belloni, R., (2001). Civil society and peacebuilding in Bosnia and Herzegovina. Journal of Peace Research, 38(2), 163-180. doi: $10.1177 / 0022343301038002003$ 
Blom, (2000). Report to possible donors for a project on: a cadastral and land registration system for Kosovo (pp. 21): Blom, International Sweden AB.

Brahimi, L., (2007). State building in crisis and post-conflict countries. Paper presented at the 7th Global Forum on Reinventing Government Building Trust in Government, Vienna, Austria. http://unpan1.un.org/intradoc/groups/public/documents/un/unpan02 6305.pdf

Bruce, J., (2007). Drawing a line under the crisis:Reconciling returnee landaccess and security in post conflict Rwanda HPG Working Papers. London, UK: Overseas Development Institute ODI.

Buyse, A. C., (2008). Post-Conflict Housing Restitution: The European Human Rights Perspective with a Case Study on Bosnia and Herzegovina. (PhD), Leiden University, Leiden, the Netherlands.

Cagdas, V. and Stubkjaer, E., (2009). Doctoral research on cadastral development. Land Use Policy, 26(4), 869-889.

Call, C. T. and Cousens, E. M., (2008). Ending wars and building peace: international responses to war-torn societies. International Studies Perspectives, 9(1), 1-21.

Cassel, C. and Symon, G., (1994). Qualitative Methods in Organizational Research. In C. Cassel and G. Symon (Eds.). C.A., USA: Sage Publications.

CAVR, (2005). The History of the Conflict Report of the Commission for Reception, Truth and Reconciliation of Timor-Leste (CAVR - the Portuguese acronym) - Chega! Dili, Timor-Leste.

Chesterman, S., Ignatieff, M. and Thakur, R., (2005). Making states work: states failure and crisis government. Tokyo, New York, Paris: United Nations Press.

COHRE, (2007). Handbook on Housing and Property Restitution for Refugees and Displaced Persons, Implementing the 'Pinheiro Principles'. New York, USA: United Nations Centre on Housing Rights and Evictions.

Collier, P., (2000). Rebellion as a quasi-criminal activity. Journal of Conflict Resolution, 44(6), 839-853. doi: 10.1177/0022002700044006008

Collier, P. and Heoffler, A., (1998). On Economic causes of civil war. Oxford Economic Papers, Oxford University Press, 50, 563-573.

Cordial, M. and Rosandhaug, K., (2008). Post-conflict property restitution the approach in Kosovo and lessons learned for future international practice. Leiden, the Netherlands: Martinus Nijhoff Publishers.

Cossa, R. and de Wit, P., (2009). Legal and policy reforms to increase security of tenure and improve land administration. Paper presented at the Proceedings: Land Governance in Support in Millennium Development Goals: Responding to New Challenges. FIG - World Bank Conference, Washington D. C. USA

Cramer, C. and Weeks, J., (2002). Microeconomic stabilization and structural adjustment. In E. a. V. Wayne, R. (Ed.), The Prevention of Humanitarian Emergencies: UNU-WIDER Palgrave.

Crotty, M., (1998). The Foundation of Social Research: Meaning and Perspective in the Research Process: Allen and Unwin.

CSIS/AUSA, (2002). Post-conflict Reconstruction: Task Framework (pp. 20). Washington DC, USA: Center for Strategic and International Studies/Association of the United States Army. 
Dabo, A., Salmon, J., Venancio, M. and Keuleers, P., (2010). Local governance, peace building and state building in post-conflict settings: a UNDP discussion paper. New York, USA: UNDP.

Dale, P. and McLaughlin, J., (1999). Land Administration. Oxford, United Kingdom: Oxford University Press.

Daudelin, J., (2003). Land and violence in post-conflict situations. NorthSouth Institute and the World Bank.

de Soysa, I., (2002). Paradise is a bazaar? Greed, creed, and governance in civil war, 1989-99. Journal of Peace Research, 39(4), 395-416. doi: $10.1177 / 0022343302039004002$

de Waal, A., (2009). Why humanitarian organizations need to tackle land issues. In S. Pantuliano (Ed.), Uncharted Territory: Land, Conflict and Humanitarian Actions (pp. 9-26). Warwickshire, UK.: Overseas Development Institute.

Du Plessis, J., (2003) Land plays a key role in post-conflict restitution. Vol. 9/4: UN-HABITAT Habitat Debate.

Enemark, S., (2003). Capacity building for developing sustainable land administration infrastructures. Paper presented at the WLPA/FIG Workshop: Spatial Information Management for Sustainable Real Estate Markets and Best Practice Guidelines on Nation-wide Land Administration. International Federation of Surveyors FIG, Athens, Greece.

Enemark, S. and van der Molen, P., (2008). Capacity assessment in land administration FIG Publication 41 (pp. 37). Copenhagen, Denmark: International Federation of Surveyors, FIG and FAO.

EU-UN, (2012). Land and conflict EU-UN partnership: toolkit and guidance for preventing and managing land and natural resources conflict. New York, USA: UN Interagency Framework Team for Preventive Action.

FAO-LSP, (2004) Post-conflict land tenure; Using a Sustainable Livelihoods Approach. Vol. LSP Working Paper. Rome, Italy: FAO.

FAO-VG, (2012) Voluntary Guidelines on the Responsible Governance of Tenure of Land, Fisheries and Forests in the Context of National Food Security. Roma, Italy: FAO.

FAO, (2005). Access to rural land and land administration after violent conflicts FAO Land Tenure Studies. Rome, Italy: United Nations Food and Agriculture Organisation (FAO).

FAO, (2006). Land tenure alternative conflict management FAO Land Tenure Manuals (Vol. 2). Rome, Italy: United Nations Food and Agriculture Organisation (FAO).

FIG, (1995). The Statement on the Cadastre FIG Publication 11 (pp. 37). Copenhagen, Denmark: International Federation of Surveyors (FIG).

Fitzpatrick, D., (2002). Land policy in post-conflict circumstances: some lessons from East Timor New issues in refugee research (Vol. Working paper No. 58). Timor-Leste.

Fitzpatrick, D., (2008). Guidelines on addressing land issues after natural disasters: April Draft, EMG, Geneva, Switzerland, 2008. .

Fukuyama, F., (2004). State building: governance and world order in the 21st century. New York, USA: Cornell University Press.

Ghani, A., Lockhart, C. and Carnahan, M., (2006). An Agenda for StateBuilding in the Twenty-first Century. Fletcher Forum of World Affairs, 30(1 (Winter)), 101-123. 
Gillingham, P. and Buckle, F., (2014). Rwanda Land Tenure Regularisation Case Study. Hertfordshire, United Kingdom: HTSPE Limited for Evidence on Demand and UK Department for International Development (DFID).

Groot, R. and van der Molen, P., (2000). Final Report from the Workshop on Capacity Building in Land Administration for Developing Countries. Enschede, the Netherlands: International Institute for GeoInformation Sciences and Earth Observations.

Guterras, A., (2009). Foreword In S. Pantuliano (Ed.), Uncharted Territory: Land, Conflict and Humanitarian Actions (pp. ix-x). Warwickshire, UK.: Overseas Development Institute.

Heinz-Jürgen, A., Milososki, A. and Schwarz, O., (2006). Conflict - a literature review Jean Monnet Group. Duisburg, Germany: Institute for Political Sciences, Department of Social Sciences, University Duisburg Essen.

Henssen, J. and Williamson, I., (1990). Land registration, cadastre and its interaction; a world perspective. Paper presented at the XIX FIG Congress, Helsinki, Finland.

HIICR, (2005). Conflict barometer 2005. Crisis, wars, coups d'état, negotiations, mediations, peace settlements. Heidelberg Institute for International Conflict Research. Retrieved 04 June, 2012, from http://www.hiik.de/en/konfliktbarometer/pdf/ConflictBarometer 200 5.pdf

Hilhorst, D. and van Leeuwen, M., (2000). Emergency and development: The case of Imidugudu, Villagization in Rwanda. Journal of Refugee Studies, 13(3), 264-280.

Hollingsworth, C., (2014). A Framework for Assessing Security of Tenure in Post-Conflict Contexts. (MSc), Faculty ITC, University of Twente, Enschede, The Netherlands. Retrieved from http://www.itc.nl/library/papers 2014/msc/la/hollingsworth.pdf

Homer-Dixon, T. F., (1999). Environment, Scarcity and Violence: Princeton University Press, Princeton, New Jersey.

HPCC, (2007). Final report of the housing and property claim commission. Pristina, Kosovo: Housing and Property Directorate, Housing and Property Claim Commission (HPCC).

HPG, (2008). Uncharted Territory: Land, Conflict and Humanitarian Actions Book Meeting Report. Birkbeck College, London, United Kingdom: Humanitarian Policy Group (HPG).

HRW, (2001). Drenica region (Vol. 5): Human Rights Watch (HRW).

Huggins, C., (2009). Land in return, reintegration and recovery processes: Some lessons from the Great Lakes region in Africa. In S. Pantuliano (Ed.), Uncharted Territory: Land, conflict and humanitarian actions (pp. 67-93). Warwickshire, UK: Overseas Development Institute.

Hutjes, J. M. and van Buuren, J. A., (1992). De gevalsstudie: Strategie van kwalitatief onderzoek [The case study: Strategy for qualitative research]. Amsterdam, the Netherlands: Open Univeristeit.

Jeong, H., (2000). Peace and Conflict Studies: An Introduction: Ashgate, Aldershot.

Joseph, C. D., (2013). Land Tenure and Human Security During Post-Conflict Development (Thesis, Doctor of Philosophy). University of Otago 
Otago, New Zealand. Retrieved from http://hdl.handle.net/10523/4120

Kato, H., (2014). Foreword of Confronting land and property problems for peace. In S. Takeuchi (Ed.), Confronting land and property problems for peace (pp. xiii-xiv). London, United Kingdom: Routledge.

KCA, (2011). Kosovo Cadastre Agency report to Ministry of Environment and Spatial Planning, Government of Republic of Kosovo. Pristina, Kosovo: Kosovo Cadastre Agency (KCA).

Korf, B. and Funfgeld, H., (2006). War and the commons: Assessing the changing politics of violence, access and entitlements in Sri Lanka. Geoforum, 37(3), 391-403. doi: 10.1016/j.geoforum.2005.08.002

KPA, (2012). Annual Report 2012. Pristina, Kosovo: Kosovo Property Agency (KPA).

LANDac, (2012). Mozambique: Food Security and Land Governance Factsheet: IS Academie on Land Governance.

Le Billon, P., (2001). The political ecology of war: natural resources and armed conflicts. Political Geography, 20(5), 561-584. doi: 10.1016/s0962-6298(01)00015-4

Leckie, S., (2000). Resolving Kosovo's housing crisis: challenges for the UN Housing and Property Directorate. Forced Migration Review, FMR(7), 12-16.

Levy, B. and Sidel, V., (1997). War and public health. New York: Oxford University Press.

Levy, D., (2006). Qualitative Methodology and Grounded Theory in Property Research. Pacific Rim Property Research Journal, 12(4).

Lewis, D., (2004). Challenges to Sustainable Peace: Land Disputes Following Conflict. Paper presented at the FIG Symposium on Land Administration in Post Conflict Areas, Geneva, Switzerland.

Lund, S. M., (1996). Preventing Violent Conflicts: A Strategy for Preventive Diplomacy. Washington D.C: United States Institute of Peace press.

Magnarella, P., (2005). The Background and Causes of the Genocide in Rwanda. Journal of International Criminal Justice, 3(4), 801-822.

Maier, R., (2010). Early recovery in post-conflict countries; a conceptual study (pp. 94): Netherlands Institute for International Relations, Clingendael Institute, the Netherlands.

Manirakiza, J. G., (2014). The role of land records in support of post-conflict land administration: a case study of Rwanda in Gasabo district. (MSc), Faculty ITC, University of Twente, Enschede, The Netherlands. Retrieved

from http://www.itc.nl/library/papers_2014/msc/la/manirakiza.pdf

Matsuzaki, R., (2011). Institutions by Imposition: Colonial Lessons for Contemporary State-Building. (PhD), Massachusetts Institute of Technology, Massachusetts, USA.

McAuslan, P., (2007). Post-conflict land administration: a note. Retrieved 21 August, 2012,

from http://info.worldbank.org/etools/docs/library/240936/Postconflict\%2 OLand\%20Adm.pdf

Meha, M., (2004). Land administration before and after the war (1999) in Kosovo. Paper presented at the Symposium on Land Administration in Post Conflict Areas, International Federation of Surveyors FIG, Geneva, Switzerland. 
Meha, M., Llabjani, B. and Bublaku, H., (2004). Development of cadastre and land management in Kosovo. Paper presented at the FIG Working Week 2004, International Federation of Surveyors FIG, Athens, Greece.

Mokokoane, M., (2014). Video statement on: how lease agreements and land records resulted in preventing the conflicts over land. Retrieved 15 February, 2014, from https://www.youtube.com/watch?v=Yie4pjdxewM

Morris, N., (1999). UNHCR and Kosovo: a personal view from within UNHCR. Forced Migration Review, $F M R(5), 14-18$.

Murekezi, A., (2012). Rebuilding after conflict and strengthening fragile states : a view from Rwanda (Vol. 22). Harare, Zimbabwe: African Capacity Building Foundation (ACBF).

Myers, G. W., (1994). Competitive Rights, Competitive Claims: Land Access in Post-War Mozambique. Journal of Southern African Studies, 20(4), 603-632. doi: $10.2307 / 2636976$

NATO, (1999). Military Technical Agreement, North Atlantic Treaty Organisation (NATO).

NEPAD, (2005). African Post-Conflict Reconstruction Policy Framework Secretariat, Governance, Peace and Security Programme. South Africa: New Partnership for Africa's Development (NEPAD)

Nyamwasa, K., Karegeya, P., Rudasingwa, T. and Gahina, G., (2010). Rwanda Briefing. Kigali, Rwanda.: Africa Faith and Justice Network.

Obama, B. H., (2009). Remarks by the U.S. President at United Nations Secretary General Ban Ki-moon's Climate Change Summit Retrieved from http://www.whitehouse.gov/the press office/Remarks-by-thePresident-at-UN-Secretary-General-Ban-Ki-moons-Climate-ChangeSummit/.

OCHA, (2005). United Nations Humanitarian Response Review. New York and Geneva: Office for the Coordination of Humanitarian Affairs (OCHA), United Nations.

OECD-DAC, (2007). Fragile States: Policy Commitment and Principles for Good International Engagement in Fragile States and Situations: OECD-DAC.

OECD, (2008). Concepts and Dilemmas of State Building in Fragile Situations, from Fragility to Resilience: Organisation for Economic Co-operation and Development (OECD).

OECD, (2010). The State's Legitimacy in Fragile Situations: Unpacking Complexities. Paris: OECD: Organisation for Economic Co-operation and Development (OECD).

Onkalo, P., Kuleta, A. and Jashari, B., (2002). Capacity building as a part of the cadastre development in Kosovo. Paper presented at the FIG XXII International Congress, International Federation of Surveyors FIG, Washington, D.C. USA.

OSCE, (1990). Charter of Paris for a New Europa. Retrieved 24 April, 2012, from http://www.osce.org/mc/39516.

OSCE, (2000). The Impending Property Crises in Kosovo - Background Report, Organisation for Security and Co-operation in Europe (OSCE).

OSCE, (2006). Municipal Profile: Pristina, Organisation for Security and Cooperation in Europe (OSCE). 
PAD, (1991). Peace Agreement Document (PAD), Cambodia. Retrieved 03 June, 2013, from http://www.usip.org/publications/peaceagreements-cambodia

PAD, (1992). General Peace Agreement Document (PAD) for Mozambique. Rome, Italy.

PAD, R., (1993). Peace Agreement between the Government of the Republic of Rwanda and the Rwandese Patriotic Front. Arusha, Tanzania.: United Nations.

Pantuliano, S., (2009). Charting the way: Integreting land issues in humanityarian action. In S. Pantuliano (Ed.), Uncharted Territory: Land, Conflict and Humanitarian Actions (pp. 193-213). Warwickshire, UK.: Overseas Development Institute.

Peluso, N. L. and Watts, M., (2001). Violent environments: Ithaca: Cornell University Press.

Potel, J., (2014). Displacement and land administration in post-conflict areas - case of Rwanda. (MSc), Faculty ITC, University of Twente, Enschede, The Netherlands. Retrieved from http://www.itc.nl/library/papers 2014/msc/la/potel.pdf

Potel, J., van der Molen, P., Boerboom, L., Todorovski, D. and de Vries, W., (2015). Displacement and Land Adminnistration. In J. Zevenbergen, W. de Vries and R. M. Bennett (Eds.), Advances in Responsible Land Administration (pp. 235-249): CRC Press (Taylor \& Francis ).

Prunier, G., (1997). The Rwanda Crisis: History of a Genocide. New York, USA.: Columbia University Press.

Putzel, J., (2009). Land governance in support of the Millennium Development Goals, a new agenda for land professionals FIG Publication No. 45. Washington D.C., USA: International Federation of Surveyors FIG and the World Bank.

Rambouillet, A., (1999). Rambouillet Accord, Interim Agreement for Peace and Self-Government in Kosovo. Paris, France: United Nations.

Ratia, J., (2000). Development of a Strategy on Land Administration in the Balkans and Especially in Kosovo United Nation Economic Commission for Europe (UN/ECE) - Secretariat on Land Administration Issues.

Republic of Serbia, (1976). Law on Land Survey and Cadastre of Lands, Republic of Serbia, Official Gazette No. 11.

Republic of Serbia, (1986). Law on Housing Relations, Republic of Serbia, Official Gazette No. 11/83,29/86, 42/86

Republic of Serbia, (1991a). Law on Changes and Supplements on the Limitation of Real Estate Transactions, Republic of Serbia for Socialistic Autonomous Province of Kosovo, Official Gazette No. 22/91.

Republic of Serbia, (1991b). Law on the Conditions, Ways and Procedures of Granting Farming Land to Citizens Who Wish to Work and Live in the Territory of Kosovo and Metohija, Republic of Serbia for Socialistic Autonomous Province of Kosovo, Official Gazette No. 43/91.

Republic of Serbia, (1992). Law on Housing, Republic of Serbia, Official Gazette No. 50/92.

Republic of Serbia, (2001). Victims of the Albanian terrorism in KosovoMetohija January 1998 - November 2001. Belgrade, Republic of Serbia: The Archive of the Government of the Republic of Serbia. 
Robben, A., (2010). Why Did They Kill? Cambodia in the Shadow of Genocide. Ethos, 38(1).

Ross, L. M., (2004). What Do We Know about Natural Resources and Civil War? Journal of Peace Research, 41(3), 337-356.

Rugege, J. S., (2013a). Judicial Reform, Public Confidence and the Rule of Law in Rwanda. Paper presented at the Key ote speach, Qatar Law Forum, London, United Kingdom.

Rugege, J. S., (2013b). Key note speech: Judicial Reform, Public Confidence and the Rule of Law in Rwanda. Paper presented at the Qatar Law Forum, London, United Kingdom.

Rurangwa, E., (2004). Land Administration in Post Conflict Situation-Rwanda Case. Paper presented at the Proceeding of FIG Commission 7 Symposium on Land Administration in Post Conflict Areas, Geneva, Switzerland.

Scott, Z., (2007). Literature Review on State-Building. Birmingham, UK: International developement Department, University of Birmingham.

Sekiguchi, M. and Hatsukano, N., (2013). Land conflicts and land registration in Cambodia: In Land and post-conflict peacebuilding. ed. J. Unruh and R.C.Williams. London: Earthscan.

Shala, X., Meha, M. and Ahmedi, S., (2015). Case Study of the Reforms on Laws for the Cadaster in the Republic of Kosovo. Paper presented at the FIG Working Week 2015, From the Wisdom of the Ages to the Challenges of the Modern World Sofia, Bulgaria.

Smith, N., (2002). Situation Review of the Land Administration Sector in Kosovo: BlomInfo A/S.

Songo, M. N., (2014). Roles of actors in early recovery post-conflict land administration in Rwanda: Rationale for guidelines improvement. (MSc), Faculty ITC, University of Twente, Enschede, The Netherlands. Retrieved from http://ezproxy.utwente.nl:2980/papers/2014/msc/la/songo.pdf

Spiegel, P. B. and Salama, P., (2000). War and mortality in Kosovo, 1998 99: an epidemiological testimony. The Lancet, 355(9222), 22042209. doi: http://dx.doi.org/10.1016/S0140-6736(00)02404-1

Stahn, C., (2005). Institutionalizing Brahimi's "Light Footprint': A Comment on the Role and Mandate of the Peacebuilding Commission. International Organizations Law Review, 2(1), 403 - 415.

Steudler, D., (2004). A framework for the evaluation of Land Administration Systems. (PhD), The University of Melbourne.

Strauss, A. and Corbin, J., (1998). Basics of Qualitative Research: Techniques and Procedures for Developing Grounded Theory. Thousand Oaks, CA, USA: Sage Publications.

Takeuchi, S., (2011). Gacaca and DDR: the diputable record of state-building in Rwanda State-building in conflict-prone countries (Vol. 32). Japan: JICA Research Institute.

Takeuchi, S., (2014). Land and property problems in peacebuilding. In S. Takeuchi (Ed.), Confronting land and property problems for peace (pp. 1-28). London, United Kingdom: Routledge.

Takeuchi, S., Katayanagi, M. and Murotani, R., (2014). Conclusion Confronting land and property problems for peace. In S. Takeuchi (Ed.), Confronting land and property problems for peace (pp. 242267). London, United Kingdom: Routledge. 
Takeuchi, S. and Marara, J., (2009). Conflict and land tenure in Rwanda (Vol. Working Paper No. 1). Japan: JICA-RI

Theisen, O. M., (2012). Climate clashes? Weather variability, land pressure, and organized violence in Kenya, 1989-2004. Journal of Peace Research, 41(1), 81-96.

Themnér, L. and Wallensteen, P., (2015). Armed Conflicts, 1946-2014. Journal of Peace Research, 52(4).

Thomas, R. M., (2003). Blending qualitative and quantitative research methods in theses and dissertations. California, USA: Corwin Press, Thousand Oaks.

Tibaijuka, K. A., (2007). Foreword A Post-Conflict Land Administration and Peacebuilding Handbook (pp. 3). Nairobi, Kenya: UN-HABITAT.

Tibaijuka, K. A., (2008). Preface. In M. Cordial and K. Rosandhaug (Eds.), Post-Conflict Property Restitution - The Approach in Kosovo and Lessons Learned for Future International Practice (pp. xiii-xiv). Leiden, the Netherlands: Martinus Nijhoff Publishers.

Todorovski, D., (2011). Characteristics of post-conflict Land Administration with focus on the status of land records in such environment. Paper presented at the FIG Working Week: Bridging the Gap between Cultures, Marrakesh, Morocco.

Todorovski, D., (2013a). Approved minutes of the interviews from the field work in Kosovo in September 2013.

Todorovski, D., (2013b). Field work report from the interviews from the field work in Kosovo in September 2013.

Todorovski, D., (2013c). Report on Skype interviews, personal communication and reports received from international land experts with work experience in post-conflict Kosovo.

Todorovski, D. and van der Molen, P., (2014). Post-conflict land administration as facilitator of the post-conflict state building; case Cambodia. Paper presented at the FIG Congress 2014, Engaging the Challenges, Enhancing the Relevance, Kuala Lumpur, Malaysia.

Todorovski, D., Van der Molen, P. and Zevenbergen, J., (2015c). Post-Conflict Land Administration; a Facilitator of the Post-Conflict State Building in the Case of Timor-Leste. Paper presented at the FIG Working Week 2015, From the Wisdom of the Ages to the Challenges of the Modern World Sofia, Bulgaria.

Todorovski, D., Zevenbergen, J. and van der Molen, P., (2012a). Can Land Administration in Post-Conflict Environment facilitate the Post-Conflict State Building? - a Research Problem. Paper presented at the FIG Working Week: Knowing to manage the territory, protect the environment, evaluate the cultural heritages, Rome, Italy.

Todorovski, D., Zevenbergen, J. and van der Molen, P., (2012b). Land administration in post-conflict environment - aspects relevant for South-East Europe. South-Eastern European Journal of Earth Observation and Geomatics, 1(2S), 47-59.

Todorovski, D., Zevenbergen, J. and van der Molen, P., (2015a). Land Adminnistration for Post-Conflict Contexts. In J. Zevenbergen, W. de Vries and R. M. Bennett (Eds.), Advances in Responsible Land Administration (pp. 73-90): CRC Press (Taylor \& Francis Group). 
Todorovski, D., Zevenbergen, J. and van der Molen, P., (2015b). Conflict and post-conflict land administration - the case of Kosovo. Survey Review, [In press]. doi: 10.1179/1752270615Y.0000000044

Todorovski, D., Zevenbergen, J., van der Molen, P. and Groenendijk, L., (2013). Post-conflict land administration and its current status as facilitator of the post-conflict state building; case Mozambique. Paper presented at the FIG Working Week 2013, Environment for Sustainability, International Federation of Surveyors FIG, Abuja, Nigeria.

TOR, (2000). Terms of reference for implementation of the Norwegian financed part of the Kosovo cadastre support programme, Terms of reference (TOR); Appendix E, 03.11.2000.

Törhönen, M. P., (2001). Developing land administration in Cambodia. Computers, Environment and Urban Systems, 25(4-5), 407-428. doi: http://dx.doi.org/10.1016/S0198-9715(00)00049-1

UN-HABITAT, (2003). An immediate measures: land management evaluation tool for emergency through to reconstruction post-conflict situations. Nairobi, Kenya: UN-HABITAT.

UN-HABITAT, (2007). A Post-Conflict Land Administration and Peacebuilding Handbook. Nairobi, Kenya: UN-HABITAT.

UN-HABITAT, (2009). Land and Conflict; Handbook for Humanitarians. Nairobi, Kenya: UN-HABITAT.

UN, (1985). Report of the Meeting of the Ad Hoc Group of experts on Cadastral Surveying and Land Information Systems Conventional and Digital Cadastral Mapping (Vol. E/CONF.77/L.1). New York, USA: Economic and Social Council.

UN, (1992). An Agenda for Peace, Preventive diplomacy, peace-making and peace-keeping. $\quad$ Retrieved 24 April, 2012, from http://www.unrol.org/files/A 47 277.pdf

UN, (1998). Housing and Property restitution in the context of the return of refugees and internally displaced persons (Vol. UN Resolution 1998/26). New York, USA: UN Sub-Commission on Protection and Promotion of Human Rights

UN, (1999a). Resolution 1244 S/RES/1244 (1999) (pp. 8). New York, USA: United Nations.

UN, (1999b). Report of the Secretary-General to the Security Council on Resolution 1244, S/1999/672 (pp. 6). New York, USA: United Nations.

UN, (1999c). Report of the Secretary-General on the United Nations Interim Administration Mission in Kosovo, S/1999/779 (pp. 25). New York, USA: United Nations.

UN, (2000). Report of the Panel on United Nations Peace Operations (The Brahimi Report). New York: United Nations.

UN, (2012). Charter of the United Nations, Chapter 1, Article 1. United Nations. $\quad$ Retrieved 24 April, 2012, from http://www.un.org/en/documents/charter/chapter1.shtml

UN/ECE, (1996). Land Administration Guidelines. New York and Geneva: United Nations Economic Commission for Europe (UN/ECE).

UN/ECE, (2005) Social and Economic Benifit of Good Land Administration. United Nations Economic Commission for Europe (UN/ECE): HM Land Registry, London, on behalf of the UNECE WPLA. 
UN/ECE, (2015). Official web-site of UN/ECE, Working Party on Land Administration Retrieved 10 January, 2015, from http://www.unece.org/housing/working-party.html

UN/FIG, (1999). The Bathurst Declaration on Land Administration for Sustainable Development. Report from the UN/FIG Workshop on "Land Tenure and Cadastral Infrastructures for Sustainable Development": Inretnational Federation of Surveyors (FIG).

UNEP, (2009) From conflict to peacebuilding: The Role of Natural Resources and Environment. Nairobi, Kenya: United Nations Environnent Programme (UNEP).

UNHCR, (1999a). Preliminary Assessment of the Situation of Ethnic Minorities in Kosovo, United Nations High Commissioner for Refugees (UNHCR).

UNHCR, (1999b). Kosovo Crisis Update, United Nations High Commissioner for Refugees (UNHCR).

UNHCR, (2012). The State of World's Refugees; in Search of Solidarity - a Synthesis, United Nations High Commissioner for Refugees (UNHCR).

UNHCR, (2014). UNHCR Global Trends 2013 - War's Human Costs, United Nations High Commissioner for Refugees (UNHCR). Retrieved 4.08.2014, 2014, from http://www.unhcr.org/5399a14f9.html

UNMIK, (1999a). On the establishment of the Housing and Property Directorate and the Housing and Property Claims Commission UNMIK/REG/1999/23. Pristina, Kosovo: UNMIK, United Nations.

UNMIK, (1999b). On the repeal of discriminatory legislation affecting housing and rights in property UNMIK/REG/1999/10. Pristina, Kosovo: UNMIK, United Nations.

UNMIK, (2000a). On the establishment of the administrative department of public services UNMIK/REG/2000/14. Pristina, Kosovo: UNMIK, United Nations.

UNMIK, (2000b). On residential property claims and the rules of procedure and evidence of the Housing and Property Directorate and the Housing and Property Claims Commission UNMIK/REG/2000/60. Pristina, Kosovo: UNMIK, United Nations.

UNMIK, (2002). Law on the establishment of immovable property rights register UNMIK Law No. 2002/22. Pristina, Kosovo: UNMIK, United Nations.

UNMIK, (2003). Law on cadastre Law No. 2003/25. Pristina, Kosovo: UNMIK, United Nations.

UNMIK, (2006). On the resolution of claims relating to private immovable property including agricultural and commercial property Pristina, Kosovo: UNMIK, United Nations.

Unruh, J., (2001). Postwar land dispute resolution: land tenure and peace process in Mozambique. International Journal of World Peace, 18(3), 23.

Unruh, J., (2004). Land and Property Rights in the Peace Process. In G. Bergess and $\mathrm{H}$. Burgess (Eds.), Beyond Intractability. Colorado, USA: University of Colorado, Conflict Research Consortium.

Unruh, J. and Williams, R., (2013a). Lessons learned in land tenure and natural resource management in post-conflict societies. In J. Unruh and R. Williams (Eds.), Land and post-conflict peacebuilding. London: Earthscan. 
Unruh, J. and Williams, R., (2013b). Land and post-conflict peacebuilding. ed. J. Unruh and R.C. Williams. London: Earthscan.

USAID, (2005) Land and Conflict - a toolkit for intervention. USAID - Office of Conflict Management and Mitigation, Washington DC, USAID.

USAID, (2012). Property rights and resources gonernance; Timor-Leste.

UU-DPCR, (2012). Uppsala University, Department for Peace and Conflict Research (UU-DPCR). Retrieved 22 August, 2012, from http://www.pcr.uu.se/research/ucdp/definitions/\#Peace agreement

UWR, (2015). Data Analysis; Pearson's Correlating Coeficient, University of the West of England, Bristol, United Kingdom. Retrieved 24 June, 2015, from http://learntech.uwe.ac.uk/da/Default.aspx?pageid=1442

Valstad, T., (2001). The reconstruction of the cadastre and the development of a land information system in Kosovo. Paper presented at the International Conference on Spatial Information for Sustainable Development, International Federation of Surveyors FIG, Nairobi, Kenya.

Valstad, T., (2004). Institution building in Kosovo - failure or success? Paper presented at the 3rd FIG Regional Conference, International Federation of Surveyors FIG, Jakarta, Indonesia.

Valstad, T., Haugholt, O. J. and Llabjani, H., (2002). Rebuilding of the cadastre in Kosovo. Paper presented at the FIG XXII International Congress, International Federation of Surveyors FIG, Washington, D.C. USA.

Van der Auweraert, P., (2012). Dealing with the 2006 Internal Displacement Crisis in Timor-Leste; Between Reparations and Humanitarian Policymaking Case Studies on Transitional Justice and Displacement.

van der Molen, P., (2002). The dynamic aspect of land administration: an often-forgotten component in system design. Computers, Environment and Urban Systems, 26(5), 361-381. doi: http://dx.doi.org/10.1016/S0198-9715(02)00009-1

van der Molen, P., (2011). Cadastres, Nations and States. Magazine on positioning, navigation and beyond.

van der Molen, P. and Lemmen, C., (2004). Land administration in postconflict areas. In P. van der Molen and C. Lemmen (Eds.), Symposium on Land Administration in Post Conflict Areas. Geneva, Switzerland: UN-HABITAT and FIG Commission 7.

van Gennip, J., (2005). Post-conflict Reconstruction and Development. Development, 48(3), 57-62.

Vikman, L., (1999). Land administration in Kosovo: United Nation Economic Commission for Europe (UN/ECE), Secretariat on Land Administration Issues in the Balkan Region.

Wallensteen, P., (2002). Understanding Conflict Resolution. War, Peace and the Global System: London: Sage Publications.

Wallensteen, P. and Moller, F., (2003). Conflict prevention: methodology for knowing the unknown Uppsala Peace Research Papers (Vol. 7). Uppsala, Sweden: Uppsala University - Department of Peace and Conflict Research.

Wallensteen, P. and Sollenberg, M., (2001). Armed Conflict 1989-2000. Journal of Peace Research, Appendix 2, 38(5), 629-644.

Wehrmann, B., (2005). Urban and Peri-urban Land Conflicts in Developing Countries. (PhD). 
Wehrmann, B., (2006). Cadasters in itself won't solve the problem: the Role of the Institutional Change and Psychological Motivation in Land Conflicts - Cases from Africa. Paper presented at the FIG 5th Regional Conference, Accra, Ghana.

Westing, A. H., (1986) Global resources and international conflict: environmental factors in strategy policy and action. Oxford: Oxford University Press.

Whaites, A., (2008). States in Development: Understanding State-building. London, United Kingdom: Department for International Development (DFID).

Witsenburg, K. M. and Adano, W. R., (2009). Of Rain and Raids: Violent Livestock Raiding in Northern Kenya. Civil Wars, 11(4), 514-538. doi: $10.1080 / 13698240903403915$

Yin, R. K., (2003). Case-study research - design and methods (Vol. 5). California, USA: Sage Publications.

Yin, R. K., (2010). Analytic Generalization. In A. J. Mills, G. Durepos and E. Wiebe (Eds.), Encyclopedia of Case Study Research (pp. 21-23). Thousand Oaks, CA, USA: SAGE Publications, Inc.

Zecevic, D., (2012). Spasi katastar Kosovo i Metohije. Retrieved 30 January, 2014, from http://www.novosti.rs/vesti/srbija.73.html:382070-Spasao-katastarKiM-od-Siptara

Zevenbergen, J., (2002). Systems of Land Registration, Aspects and Effects. (PhD), Delft University.

Zevenbergen, J. and Burns, T., (2010). Land administration in post-conflict areas; a key land and conflict issue. Paper presented at the FIG XXIV Congress: Facing the Challenges - building the Capacities, International Federation of Surveyors FIG, Sydney, Australia.

Zevenbergen, J. and van der Molen, P., (2004). Legal aspects of land administration in post-conflict areas. In P. van der Molen and C. Lemmen (Eds.), Symposium on Land Administration in Post Conflict Areas. Geneva, Switzerland: UN-HABITAT and FIG Commission 7.

Zherka, I., Malazogu, R. and Tullumi, S., (1999). Land Rights Issues in the Balkans, United Nations Economic Commission for Europe (UN/ECE). London, United Kingdom. 


\section{Appendix}

Case study areas and structure of informants from three MSc theses used for the Chapter 4 - the case of Rwanda

$1^{\text {st }}$ MSc thesis addressing the topic of: The role of land records in support of post-conflict land administration: a case study of Rwanda in Gasabo district (Manirakiza, 2014).

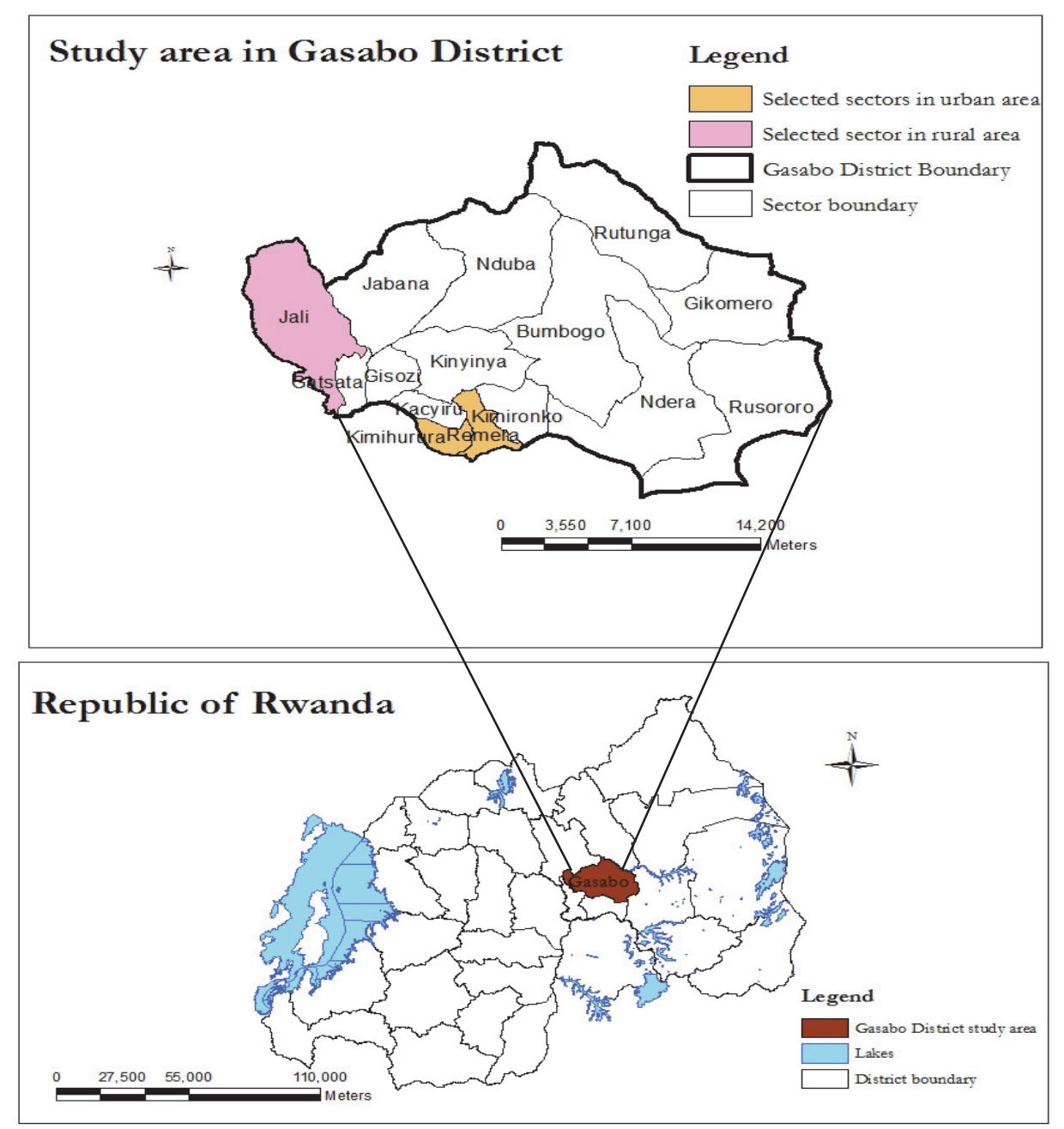

Figure.1: Location of the study areas (Manirakiza, 2014) 
Table 1: Categories of respondents to questionnaires (Manirakiza, 2014)

\begin{tabular}{|l|l|c|}
\hline No & Categories of respondents & $\begin{array}{l}\text { Number } \\
\text { respondents }\end{array}$ \\
\hline 1 & $\begin{array}{l}\text { Land claimants: People who did not flee the } \\
\text { country }\end{array}$ & 14 \\
\hline 2 & Land claimants: Returnees of 1959 & 3 \\
\hline 3 & Land claimants: Returnees of 1994 & 17 \\
\hline 4 & $\begin{array}{l}\text { Member of local arbitration committees } \\
\text { called "Abunzi" }\end{array}$ & 4 \\
\hline 5 & $\begin{array}{l}\text { Current Land administrators at Rwanda } \\
\text { Natural Resources Authority (RNRA) }\end{array}$ & 6 \\
\hline 6 & Former Land administrators & 49 \\
\hline Total &
\end{tabular}

Table 2: Key informants during primary data collection using interviews (Manirakiza,

\begin{tabular}{|l|l|c|}
\hline No & Categories of respondents & $\begin{array}{l}\text { 2014) } \\
\text { respondents }\end{array}$ \\
\hline 1 & $\begin{array}{l}\text { Deputy Director General in Charge of Land and } \\
\text { Mapping Department }\end{array}$ & 1 \\
\hline 2 & Former Registrar at Ministry level after the conflict & 1 \\
\hline 3 & District Land Officer & 1 \\
\hline 4 & $\begin{array}{l}\text { Former staff in the Ministry in charge of refugees and } \\
\text { social reintegration (MINIREISO) }\end{array}$ & 1 \\
\hline 5 & $\begin{array}{l}\text { Former staffs of Ministère des Travaux Publics } \\
\text { (MINITRAPE) }\end{array}$ & 3 \\
\hline Total & \multicolumn{1}{|c|}{} \\
\hline
\end{tabular}

$2^{\text {nd }}$ MSc thesis addressing the topic of: Displacement and land administration in post-conflict areas - case of Rwanda (Potel, 2014). 

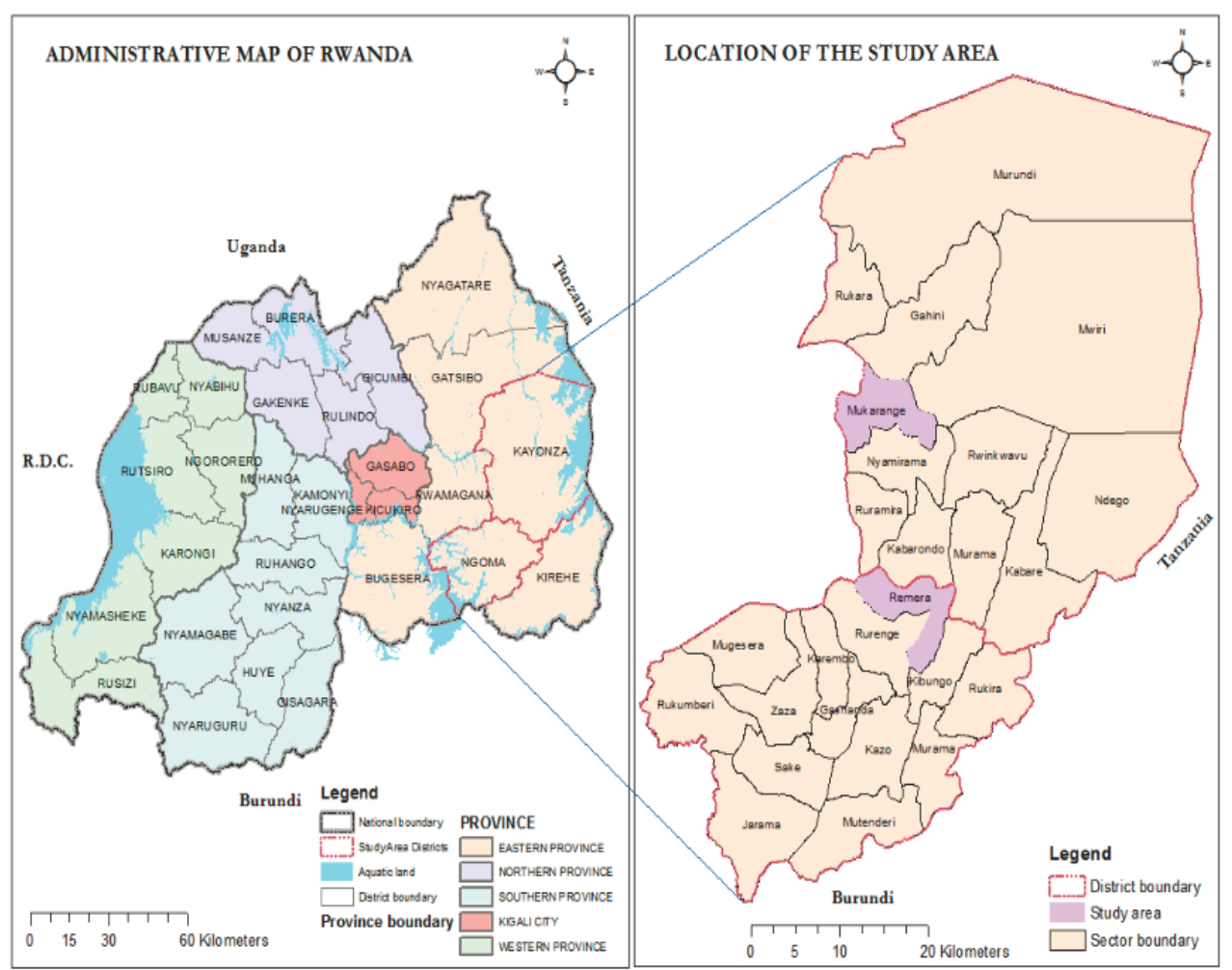

Figure 2: Location of the study areas (Potel, 2014)

Table 3: Interviewed Leaders and Former Leaders (Potel, 2014)

\begin{tabular}{|c|c|c|}
\hline Organization & Position & Number \\
\hline Kayonza District & Mayor & 1 \\
\hline Ngoma District & Vice Mayor & 1 \\
\hline Remera Sector & Executive Secretary & 1 \\
\hline Kayonza & $\begin{array}{c}\text { Director of Land } \\
\text { Administration }\end{array}$ & 1 \\
\hline Central Government & $\begin{array}{c}\text { Former Minister of Local } \\
\text { Government, Prefet of } \\
\text { Former Kibungo Prefecture } \\
\text { and a member of } \\
\text { Repatriation Commission }\end{array}$ & \\
\hline Ngoma District & Former Councillors & 3 \\
\hline & Former Councillors & 12 \\
\hline
\end{tabular}


Table 4: Number of Respondents and their respective sectors (Potel, 2014)

\begin{tabular}{|c|c|c|c|}
\hline No & Targeted groups & $\begin{array}{c}\text { Respondents from } \\
\text { Mukarange sector }\end{array}$ & $\begin{array}{c}\text { Respondents from } \\
\text { Remera sector }\end{array}$ \\
\hline 1. & 1959 refugees & 4 & 5 \\
\hline 2. & 1994 refugees & 4 & 3 \\
\hline 3. & IDP's & 4 & 3 \\
\hline 4. & Survivors & 4 & 4 \\
\hline & \multicolumn{3}{|c|}{$\mathbf{3 1}$} \\
\hline & \multicolumn{3}{|c}{} \\
\hline
\end{tabular}

$3^{\text {rd }}$ MSc thesis addressing the topic of: Roles of actors in early recovery postconflict land administration in Rwanda: Rationale for guidelines improvement (Songo, 2014). 


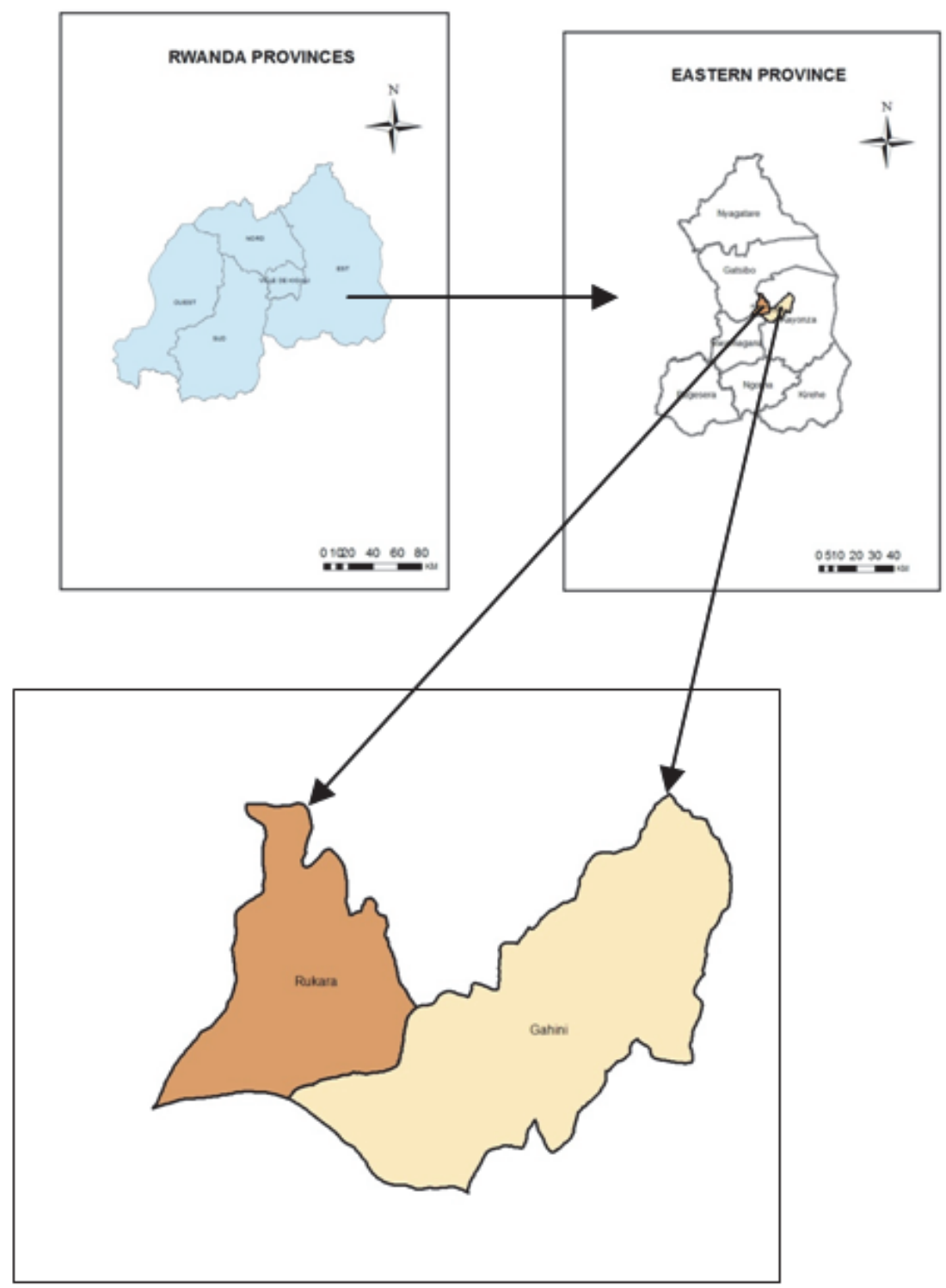

Figure 3: Location of the study areas (Songo, 2014) 
Table 5: Interviewed Key informants (Songo, 2014)

\begin{tabular}{|l|l|l|}
\hline Actor category & Key informants & $\begin{array}{l}\text { Number of } \\
\text { respondents } \\
\text { interviewed }\end{array}$ \\
\hline GOVERNMENT & Policy makers & 1 \\
\cline { 2 - 3 } & $\begin{array}{l}\text { Government land official ( Land } \\
\text { and Mapping department) }\end{array}$ & 1 \\
\cline { 2 - 3 } & Former government land officials & 1 \\
\cline { 2 - 3 } & $\begin{array}{l}\text { Land professionals in Kayonza } \\
\text { district in Eastern province }\end{array}$ & 1 \\
\cline { 2 - 3 } & $\begin{array}{l}\text { Head of sector (Gahini sector) in } \\
\text { Kayonza district }\end{array}$ & 1 \\
\cline { 2 - 3 } & $\begin{array}{l}\text { Head of sector (Rukara sector) in } \\
\text { Kayonza district }\end{array}$ & 1 \\
\hline CITIZENS & $\begin{array}{l}\text { Citizens (Gahini sector) in } \\
\text { Kayonza district }\end{array}$ & 7 \\
\cline { 2 - 3 } & $\begin{array}{l}\text { Citizens (Rukara sector) in } \\
\text { Kayonza district }\end{array}$ & 10 \\
\hline ADVOCACY \\
GROUP & Academicians in land profession & 2 \\
\cline { 2 - 3 } & TOTAL & $\mathbf{2 5}$ \\
\hline
\end{tabular}




\section{Summary}

Land and its administration are always negatively affected during conflicts and in post-conflict contexts. This has been confirmed both in the literature and in practice. This research has shown that if land and its administration are neglected or not properly addressed after the end of a conflict, they can be a cause for a renewed armed conflict and an obstacle in the rebuilding of a post-conflict society. The author's initial research on the topic revealed that there is a relation between land administration and post-conflict state building. Therefore, the main research objective was to identify which interventions in land administration and under which circumstances facilitate post-conflict state building.

In order to achieve the main research objective, a qualitative research approach was applied on two main case studies: Kosovo and Rwanda. Findings from the main case studies were supported with three supportive case studies: Mozambique, Cambodia and Timor-Leste, by collecting data from the literature. Empirical data and literature were used to set the theoretical propositions as: (1) a framework for rebuilding post-conflict states, and (2) interventions in land administration for post-conflict state building. For the final discussions and for the analytical generalisation correlating analyses were performed in a three-dimensional matrix, where the theoretical propositions (1) and (2) formed a skeleton of the matrix and empirical data from the main case studies constitutes the third dimension. The research first derived general findings on land, conflict and post-conflict contexts and, finally, specific findings were presented as in the framework for rebuilding post-conflict states grouped as: institutional weaknesses, economic and social problems, and serious security problems.

As to general findings on land, conflict and post-conflict contexts, this research showed that in some cases land was a major cause or it was one of many factors that influenced the eruption of armed conflict. Therefore, it revealed that land issues required specific attention during the state building in post-conflict contexts. This confirmed the recognition that all conflicts have a land dimension. Additional confirmation from the lessons learned from the cases shows it is beneficial that specific interventions in land administration and land-related issues should be included in the peace agreement documents integrated in the UN operations. Findings from this research showed that, if this was not the case, the development of the land segment occurred later, resulting in complicating and slowing down the post-conflict state building. Where applicable it was beneficial to quickly adopt ad hoc land policies, which strengthened the legitimacy of the state and supported the political stability, as was shown in the case of Rwanda. Developments in the land sectors with reference to land legislation, organisations with mandate for 
its enforcement, and participation by citizen and authorities involved, as was shown in researched cases, contributed to the rule of law in post-conflict contexts.

In regard of institutional weaknesses, this research shown that development of a National Land Policy in post-conflict contexts resulted in a benefit to all related users. This was most efficient when it was developed within a broader National Development Strategy, jointly created and accepted by all related stakeholders. The land policy needs to contain clear directions about the development of the land law and appointment of specific organisations with a mandate for enforcement of the law and the policy. In all researched cases the creation of specific organisations, such as land administration organisations and land-claims commissions, revealed that this supported the governmental structure and strengthened the weak post-conflict political system. In addition, capacity building was required and implemented in relation to: the legal framework, the creation of organisations, the education and training of land professionals and equipment. Building capacities in all cases were supported by assistance from international actors or development partners. Findings from this research have shown that the mentioned landrelated activities are most effective and efficient when developed with international assistance and through implementation programmes. Interventions in land administration, as discussed in the final analyses, contributed to improvement in the low legitimacy of the political leaders and legitimacy of the state as well. For one of our cases, Rwanda, findings showed that building the legitimacy of the state initially was based on the ad hoc land sharing policy, allocation of state land, and housing and village settlements.

In regard of economic and social problems, this research concluded the following. Addressing the specific land management/administration intervention within the peace agreement documents in three researched cases, and addressing land issues as regards displaced persons as in all cases, was a first step of involvement of land and its administration in the improvement of the economic and social situation in post-conflict contexts. In addition, the creation of specific land-claim commissions and land administration organisations supported the population and specifically the displaced people in settling the land disputes and reduced the social and security tensions. The aim of land administration organisations is the creation or improvement of the land registration and land administration system. Our cases showed that this was successfully realized, supported by implementation programmes or projects, which further contributed to a sustainable development and supported the real property market. The success of the implementation programmes and projects, as was the case in both main-case studies, reveals that it influenced the economic development 
and reduced social tensions. Development of land administration, specifically in the creation of land records in four cases or recovery of the land records (as in the case of Kosovo), contributed to the service provision to all landrelated sectors and significantly increased the security of land rights. This supported the establishment of the land market and improved the overall economic development. This research showed that when land records become available, provision of land products and services assisted the requirements of displacement and destroyed properties.

The security situation in post-conflict contexts by default is tense and fragile, with a large military presence. Addressing specific land management/ administration (in three cases) and land related issues in regards of displaced population in the peace agreement document, as was shown in all five cases of this research, to some degree contributed to address the difficult security situation. Land dispute and claim mechanisms (using mediation or adjudication methods) were adequately developed in each of our cases. In addition, this research revealed that these mechanisms are seen as instruments that supported the settlement of the disputes over land and reduced conflict tensions.

Main findings from this research lead to conclusion that the identified interventions in land administration can be seen as facilitators of post-conflict state building. 


\section{Samenvatting}

Grondbezit en grondregistratie (kadasters) hebben altijd veel te lijden in tijden van conflict en daarna. Dit zien we niet alleen in de realiteit van alledag: ook wetenschappelijk onderzoek heeft het bevestigd. Zo blijkt dat geen of onvoldoende aandacht voor een goede regeling van grondbezit en grondregistratie als het conflict eenmaal voorbij is, een obstakel vormt voor de opbouw van de samenleving, als het al geen aanleiding is voor een oplaaiing van het oude conflict. In eerder onderzoek door de promovendus waren er al indicaties dat er een relatie zou kunnen bestaan tussen de manier waarop na een conflict met grondbezit en grondregistratie wordt omgegaan en de ordentelijke wederopbouw van de Staat. Dit leidde tot de hoofddoelstelling van het onderhavige promotieonderzoek, namelijk wat kunnen we zeggen over de interventies die zijn gedaan om grondbezit en grondregistratie na een conflict weer op de rails te krijgen en hoe hebben deze interventies bijgedragen aan de wederopbouw van de staat.

Om hierover wetenschappelijk verantwoorde uitspraken te kunnen doen, is in het kader van deze promotie onderzoek volgens de kwalitatieve methode gedaan in twee landen, namelijk Kosovo en Rwanda. Dit waren diepgaand casestudies, die ondersteund werd door studies in drie andere landen, namelijk Mozambique, Cambodia, en Oost Timor. Deze drie studies beperkten zich tot literatuuronderzoek. Wat in eerste instantie uit het onderzoek naar voren kwam, kon gevat worden in een tweetal theoretische uitgangspunten. In de eerste plaats kon een raamwerk worden ontwikkeld hoe de wederopbouw van staten verloopt. In de tweede plaats kon een lijst met interventies worden ontwikkeld die gedaan werden om grondbezit en grondregistratie weer op gang te krijgen. Vervolgens konden deze thema's als twee assen in een matrix vorm worden geconfronteerd met de bevindingen in de onderzochte landen waardoor analyse, discussie en generalisatie kon plaatsvinden. Het onderzoek kon daarmee algemene aspecten afleiden betreffende grondbezit en grondregistratie in en na conflicten, alsmede specifieke aspecten daar waar het betreft de drie karakteristieken van staten in wederopbouw, namelijk institutionele ontwikkeling, economische en sociale ordening, en verbetering van de veiligheidssituatie.

Wat betreft het eerste, de meer algemene aspecten, heeft het onderzoek aangetoond dat conflicten omtrent grondbezit in sommige gevallen de hoofdoorzaak dan wel één van de oorzaken is geweest van de escalatie tot een gewapend conflict. Eigenlijk hebben alle conflicten dus een 'grondbezit' dimensie. Als zo'n gewapend conflict voorbij is, en de wederopbouw van de staat vangt aan, dan is veel aandacht nodig voor een ordentelijke regeling van grondbezit, of het nu bijvoorbeeld gaat om toegang en tot grondbezit, de 
juridische regeling ervan (eigendom, pacht), de waarborging (kadasters), huisvesting, of het sociaal wenselijke gebruik (ruimtelijke ordening). Aanvullende informatie uit de diverse casestudies heeft geleerd dat het daarom van het grootste belang is dat reeds in vredesakkoorden afspraken worden gemaakt over hoe men het grondbezit gaat regelen en welke interventies daarvoor nodig zijn, zodat die bijvoorbeeld geïntegreerd kunnen worden met Verenigde Naties inzet ter plekke. Als dat niet gebeurt, zo blijkt uit het onderzoek, komt de regeling van het grondbezit en de interventies die daarvoor nodig zijn pas veel later in het vizier, waardoor het vaak al te laat is en schade worden toegebracht aan de wederopbouw. De casus of Rwanda liet bijvoorbeeld zien, hoe de regering onmiddellijk een ad-hoc 'grondpolitiek' vaststelde waardoor een snelle aanpak van de problemen rondom grondbezit mogelijk werd, die bijdroeg aan de versterking van de legitimiteit van de Staat en zodoende aan politieke stabiliteit in het land. Ook toonden de casestudies aan dat daar waar veel aandacht was voor grond gerelateerde wetgeving, voor uitvoeringorganisaties met een helder mandaat, en voor participatie van de bevolking, de rechtsstatelijkheid ('rule of law') aanzienlijk werd bevorderd.

Meer in het bijzonder betreffende de institutionele zwakheid waaraan staten in wederopbouw vaak te lijden hebben, heeft het onderzoek aangetoond dat de ontwikkeling van een nationale grondpolitiek tot voordeel strekt van burgers en autoriteiten (voor de goed orde: een 'grondpolitiek' zoals Nederland die heeft, gaat vooral over de ruimtelijke ordening en de financiering daarvan; internationaal wordt met 'grondpolitiek' echter aangeduid hoe een land wil omgaan met alle aspecten van grondbezit, ook bijvoorbeeld het vraagstuk hoe terugkerende vluchtelingen weer een huis krijgen). Het is doelmatig om zo'n grondpolitiek onderdeel te laten zijn van een nationale ontwikkelingsstrategie, bij voorkeur ontwikkeld met en aanvaard door belanghebbenden. De grondpolitiek moet in ieder geval duidelijkheid scheppen over welke grond gerelateerde wetgeving nodig is, en welke organisaties worden opgedragen om die uit te voeren. In alle casestudies is gebleken dat de inrichting van specifieke organisaties zoals een dienst voor openbare registers en een kadaster en een land-claims commissie bijdroeg tot een heldere overheidsstructuur en aan de versterking van het politieke systeem (dat meestal na een conflict bepaald zwak is). Daarmee in samenhang bleek capaciteitsopbouw belangrijk te zijn, met name in relatie tot de wetgeving, organisatieontwikkeling, training en technisch instrumentarium. Een dergelijke capaciteitsopbouw werd in alle casestudies ondersteund door internationale donoren of ontwikkelingspartners. Het bleek overigens dat internationale hulp bij de uitvoering van de nationale grondpolitiek in brede zin groot nut heeft gehad. Interventies blijken per saldo bijgedragen te hebben aan een betere legitimiteit van politieke autoriteiten en van de overheid. 
Daar waar het gaat om de problemen van economische en sociale aard, heeft dit promotieonderzoek aangetoond dat interventies in grondbezit-kwesties zoals die opgenomen waren in vredesakkoorden (in drie casestudies), hebben geleid tot verbetering van de economische en sociale situatie van deze landen. Datzelfde gold voor de aanpak van de terugkeer van gevluchte burgers en hun toegang tot grondbezit (huisvesting) bij ommekomst (in twee casestudies). Ook hier bleek dat de inrichting van specifieke organen om land claims op te lossen ( zoals 'land claim commissions') alsmede van organisaties om onroerende zaak wetgeving uit te voeren, heeft geleid tot een ondersteuning van de burgers en in het bijzonder zij die terugkeren na gevlucht te zijn. Dit heeft spanningen tussen burgers verminderd, spanningen die altijd aanwezig zijn als vluchtelingen terugkeren naar hun huis, en ontdekken dat het bewoond is door vreemden, dan wel geheel vernietigd. Meer in het algemeen hebben de organisaties die belast waren met de regeling van het grondbezit, de registratie en waarborging daarvan, goed werk verricht, blijkt uit de casestudies. Vaak werd gewerkt volgens specifieke implementatieprogramma's of -projecten en dat leidde -net als bij de land claim commissies- tot vermindering van sociale spanningen. Ook kwam de onroerend goed markt tot enige ontwikkeling, mede dank zij de betere registratie van eigendomsrechten en de overheidsdienstverlening daaromtrent (4 casestudies), dan wel het herstel daarvan (case studie Kosovo). Daarmee werden onroerend goed transacties bevorderd, hetgeen goed was voor het geheel van economische transacties.

De veiligheidssituatie in landen die net uit een conflict komen is altijd zeer fragiel en gespannen, met een grote militaire aanwezigheid. In drie casestudies bleek dat een opname in het vredesakkoord van de grondbezitkwestie in zeker mate bijdroeg aan een verbetering van het gevoel van veiligheid. Dat gold eveneens voor de in vijf casestudies waargenomen opname in het vredesakkoord van de voorgenomen wijze van omgaan met terugkerende vluchtelingen. In ieder van de casestudies bleek dat er mechanismen werden ingericht om conflicten tussen burgers over grondbezit dan wel over claims op te lossen (zoals bemiddeling en arbitrage). Ook bleek dat deze mechanismen redelijk goed hebben gewerkt en spanningen hebben verminderd.

Al met al, leidt dit promotieonderzoek tot de conclusie dat de wederopbouw van staten die herstellen van een conflict, wordt gefaciliteerd door interventies in grondbezit en -registratie. 


\section{Biography}

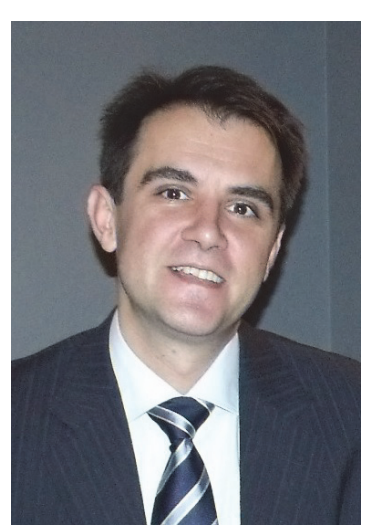

Dimo Todorovski was born on the $4^{\text {th }}$ of June 1970 in Skopje, Republic of Macedonia. He became geodetic engineer, at the Faculty of Civil Engineering, University 'Ss Cyril and Methodius', Skopje in 1997. Over the 19 years of his professional engagement (1992-2011) in the Agency for Real Estate Cadastre in the Republic of Macedonia, last 12 years were on different managerial positions (digitizing, GIS, analogue and digital archive, and Geo-ICT departments), and in the final year he was head of the department for international cooperation and European integrations. He obtained master of sciences (MSc) degree in Geo-Information Science and Earth Observation, specialisation Geo-Information Management in 2006, at the International Institute for Geo-Information Science and Earth Observation - ITC in Enschede, the Netherlands.

Since July 2011, he is working on his PhD research project at the Faculty of Geo-Information Science and Earth Observation - ITC, University of Twente. In the period of 2012-2014 he was a secretary of the UNU School for Land Administration Studies, and was giving lectures in regard of his PhD and MSc topics to the students of Land Administration Programme. During the course of his PhD project, he has attended different advanced courses such as 'Land, Property and Conflict' at United States Institute for Peace, Washington D.C. USA and presented a scientific paper at the XXV FIG Congress 2014, in Kuala Lumpur, Malaysia. His research focuses on land administration in conflict and post-conflict contexts as a facilitator of post-conflict state building. Some of his recent publications are following.

\section{List of publications}

\section{i. ISI Science of Web of Knowledge}

1. Todorovski D., Zevenbergen J. and van der Molen P., (2015). Conflict and post-conflict land administration - the case of Kosovo. Survey Review, pp.13 [In press] DOI: 10.1179/1752270615Y.0000000044.

\section{ii. Other referred Journals}

1. Todorovski, D., Zevenbergen, J. and van der Molen, P., (2015). Conflict and post-conflict contexts in relation to land, other resources and land 
administration. In: Micro Macro \& Mezzo Geo Information, 5(2015), pp. 45-63.

2. Todorovski, D., Zevenbergen, J. and van der Molen, P., (2012). Land administration in post-conflict environment - aspects relevant for SouthEast Europe. South-Eastern European Journal of Earth Observation and Geomatics, 1(2S), pp. 47-59.

\section{iii. Book Chapters}

1. Todorovski, D., Zevenbergen, J. and van der Molen, P., (2015). Land Adminnistration for Post-Conflict Contexts. In J. Zevenbergen, W. de Vries and R. M. Bennett (Eds.), Advances in Responsible Land Administration (pp. 73-90): CRC Press (Taylor \& Francis Group)

2. Potel, J., van der Molen, P., Boerboom, L., Todorovski, D. and de Vries, W., (2015). Displacement and Land Adminnistration. In J. Zevenbergen, W. de Vries and R. M. Bennett (Eds.), Advances in Responsible Land Administration (pp. 235-249): CRC Press (Taylor \& Francis Group).

3. Todorovski, D. and van der Molen, P., (2014). Post-conflict land administration as facilitator of the post-conflict state building; case Cambodia. XXV FIG Congress 2014, Engaging the Challenges, Enhancing the Relevance, Kuala Lumpur, Malaysia.

iv. Conference proceedings (peer reviewed papers)

1. Todorovski, D., Van der Molen, P. and Zevenbergen, J., (2016). PostConflict Land Administration, Facilitator of the Post-Conflict State Building. FIG Working Week 2016, Recovery from Disaster, Christchurch, New Zealand. [In press].

2. Todorovski, D., Van der Molen, P. and Zevenbergen, J., (2015). PostConflict Land Administration; a Facilitator of the Post-Conflict State Building in the Case of Timor-Leste. FIG Working Week 2015, From the Wisdom of the Ages to the Challenges of the Modern World, Sofia, Bulgaria.

3. Todorovski, D., Zevenbergen, J. and van der Molen, P., (2012). Can Land Administration in Post-Conflict Environment facilitate the PostConflict State Building? - a Research Problem. FIG Working Week: Knowing to manage the territory, protect the environment, evaluate the cultural heritages, Rome, Italy.

4. Todorovski, D., (2011). Characteristics of post-conflict Land Administration with focus on the status of land records in such environment. FIG Working Week: Bridging the Gap between Cultures, Marrakesh, Morocco. 


\section{v. Conference proceedings (full papers)}

1. Todorovski, D., Zevenbergen, J. and van der Molen, P., (2016). Which interventions in land administration facilitate post-conflict state building? Annual World Bank Conference on Land and Poverty 2016, Scaling up Responsible Land Governance. Washington D.C., USA. [In press].

2. Todorovski, D., (2015). Conflict related displacement and post conflict land administration. LANDac international conference on land governance for equitable and sustainable development, Utrecht, The Netherlands.

3. Todorovski, D., Zevenbergen, J., van der Molen, P. and Groenendijk, L., (2013). Post-conflict land administration and its current status as facilitator of the post-conflict state building; case Mozambique. FIG Working Week 2013, Environment for Sustainability, International Federation of Surveyors FIG, Abuja, Nigeria. 


\section{ITC Dissertation List}

http://www.itc.nl/research/phd/phd graduates.aspx 